\title{
The Illuminated City An Atlas of Islamic Space in Montreal
}

\author{
by \\ Marie Eve Lefebvre
}

A thesis submitted to the Faculty of Graduate and Post Doctoral Affairs in partial fulfillment of the requirements for the degree of

\section{Master of Architecture}

Azrieli School of Architecture

Carleton University

Ottawa / Canada

(C) 2018

Marie Eve Lefebvre 


\begin{abstract}
Many everyday Islamic spaces in the "West" are often almost undetectable. In Montreal, zoning regulations, economic restrictions, and the recurring debate surrounding religious accommodations significantly impact how and where Muslim communities choose to establish their places of worship. These buildings are present, yet often hidden in the physical urban fabric deemed secular - that surrounds us.
\end{abstract}

This thesis explores questions of visibility / invisibility, and secular / sacred space: what is it that we call the secular public space? How does it compare to religious or sacred space, and how permeable is it to the non-secular? Where does the sacredness of a place rest? How do the different places of worship in a city connect together?

The intent is to investigate this theological landscape as a vernacular that is repurposed into the religious space and place of a community, and to study ways to make these religious spaces visible, to reveal another landscape in and within Montreal. 


\section{Acknowledgments}

I would like to thank my advisor, Ozayr Saloojee, for his guidance and creativity in helping me finding new ways to look at my subject and to think about this research.

Merci à mes parents, François Grégoire et Monique Lefebvre, pour leur soutien et leur aide indéfectible, ainsi qu'à ma famille pour leur intarissable enthousiasme à chaque fois que j'entreprends un nouveau projet.

I would also like to thank the Building 22 staff and particularly Mark MacGuigan and Rob Wood for their infinite patience, and Steve McLeod for letting me play with lasers.

Finally, thank you to my colleagues and friends, and especially to the Oz Squad and the M.Arch 1 dog pack. 
In loving memory of Claire Barabé Lefebvre.

En marchant vite, ça paraitra pas. 


\section{Table of Contents}

Introduction

p. 01

PART I: Context

History

p. 07

Secularism

p. 14

Hatred

p. 17

Space

p. 19

Sacred

p. 20

Public

p. 23

Visibility

p. 24

Power

p. 27

Mosques

p. 30

PART Il: Itineraries

Building the Map

p. 39

Observations

p. 40

Photography

p. 42

Positive / Negative

p. 49

Illumination

p. 55

Interpretation

p. 58

Fabric

p. 66

PART III: Narratives

Drawing process

p. 71

Visibility

p. 73

Movement

p. 75

Opacity

p. 77

Threshold

p. 79

Façade

p. 81

Design Reflections

p. 84

Conclusion

p. 87

Sources

p. 98 


\section{List of Illustrations}

Fig. 01: Emblems of the Quiet Revolution p. 09

Fig. 02: Gérard Bouchard and Charles Taylor p. 12

Fig. 03: Woman donning Quebec's flag p. 13

Fig. 04: Hate Crimes in Quebec, 2013 - 2017 p. 18

Fig. 05: Protests in Montreal p. 29

Fig. 06: Place d'Armes in Montreal p. 32

Fig. 07: Church of the Madonna della Difesa p. 33

Fig. 08: Saint Joseph's Oratory p. 33

Fig. 09: Madani mosque in Montreal p. 35

Fig. 10: Map of Islamic places of worship p. 39

Fig. 11: Broken windows $\quad$ p. 40

Fig. 12: Mosque in an apartment building p. 41

Fig. 13: 'Pitheads', Bernd and Hilla Becher, $1974 \quad$ p. 43

Fig. 14: Madinah mosque in Parc-Extension p. 44

Fig. 15: 8 mosques $\quad$ p. 45

Fig. 16: Atlas and experiential drawings p. 48

Fig. 17: Etched photographs on a light table p. 49

Fig. 18: 2 etched photographs p. 50

Fig. 19: Henri Matisse, Formes, $1947 \quad$ p. 51

Fig. 20: X-ray picture of a thoracic cavity p. 52

Fig. 21: Al-Rawdah mosque, positive and negative p. 53

Fig. 22: Backlit frame with speculative section p. 54

Fig. 23: Sketch of Shah Jalal Islamic Centre p. 55

Fig. 24: Shah Jalal Islamic Centre, 1:200 model p. 56

Fig. 25: Shah Jalal Islamic Centre, 1:200 model p. 57

Fig. 26: Etched picture of Al-Jamieh Islamic Centre p. 59

Fig. 27: Model of Al-Jamieh Islamic Centre p. 59

Fig. 28: Photo \& model of Al-Rawdah mosque p. 60

Fig. 29: Photo \& model of Ach-Choura Centre p. 61

Fig. 30: Photo \& model of Al-Omah Al-Islamiah mosque p. 62

Fig. 31: Photo \& model of Islamic Centre of Verdun p. 63 
Fig. 32: Models and etched photographs

p. 64

Fig. 33: Illuminated models

p. 65

Fig. 34: Wool map of itineraries

p. 67

Fig. 35: 3 itineraries on the wool map

p. 69

Fig. 36: Perceptive map by Andrea Ponsi

p. 72

Fig. 37: Visibility

p. 74

Fig. 38: Movement

p. 76

Fig. 39: Opacity

p. 78

Fig. 40: Threshold

p. 80

Fig. 41: Façade

p. 82

Fig. 42: Thesis defence

p. 83 


\section{List of Appendices}

Appendix 01: My Grandmother Washes Her Feet in the Sink of the Bathroom at Sears p. 89

Appendix 02: The Emerald Mosque on the Hill p. 91

Appendix 03: Different Ways to Pray p. 92

$\begin{array}{ll}\text { Appendix 04: Ramadan } & \text { p. } 94\end{array}$

Appendix 05: Prayer Rug p. 95 


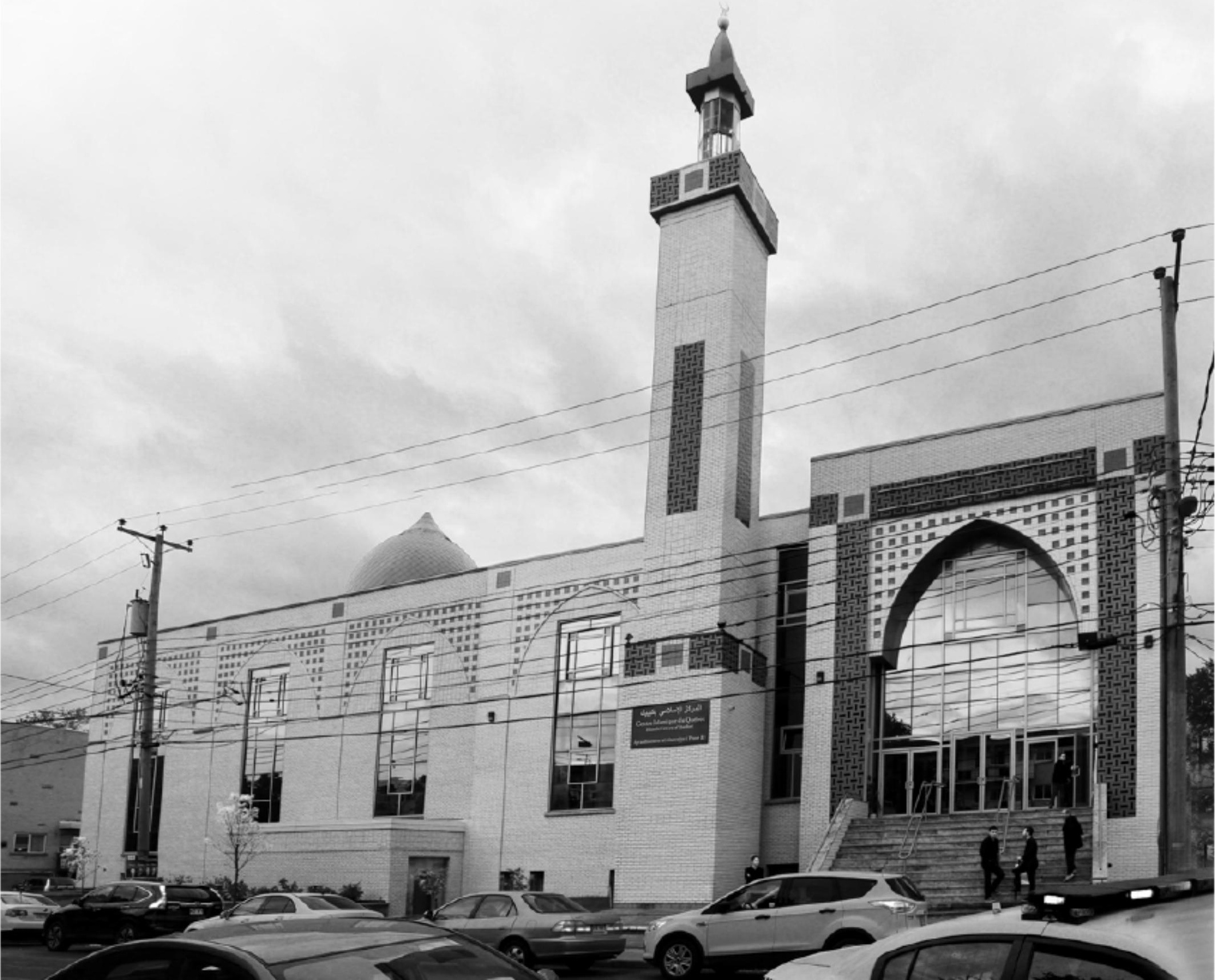




\section{Introduction}

Since 2006, several highly publicized cases of religious accommodation have created a deep sense of unease in Quebec. These accommodations attacked some values cherished by Quebecers, such as equality between women and men and the religious neutrality of the state. [...] These guidelines will benefit all Quebecers, including newcomers. We will be better served by a state that treats all of us equally. ${ }^{12}$

These are the introductory sentences of a document issued in September 2013 by the Parti Québécois (PQ) to promote their Charter of Quebec Values, a project that was later tabled in November. The project had been circulating under the appellation Charte de la laïcité since the PQ's election in 2012, but it is at the end of the summer of 2013 that information regarding the proposed concrete measures - the ban of ostentatious religious signs from the public sector, among others - began to leak. Once it became public, Premier Pauline Marois and Democratic Institutions Minister Bernard Drainville argued that the Charter would provide "clear rules for religious accommodations, ${ }^{3}$ guidelines of sorts that would help public

\footnotetext{
1 Gouvernement du Québec, "Parce que nos valeurs, on y croît," official

${ }^{2}$ All translations of official documents are made by the author. An archive of this version of Parce que nos valeurs, on y croit, the official governmental document explaining the proposed Charter project, can be found online at http://www.nosvaleurs.gouv.qc.ca/medias/pdf/Valeurs_depliant_version_longue. pdf

"Gouvernement du Québec, "Parce que nos valeurs, on y croît," official government document, September 2013.
} 
institutions and publicly funded businesses to deal with religious accommodations requests.

Instead, the situation degenerated promptly. As the debate started to focus primarily on Muslim women wearing the hijab, the niqab, and the burqa, many women's centers reported a dramatic rise in violence aimed at Muslim women across the province ${ }^{4}$. In October 2012, the Quebec's Human Rights and Youth Rights Commission took an official position against the proposed Charter, stating that its adoption would be a radical infringement on fundamental rights, and thus expressed its "complete opposition" to the project, calling it "systemic discrimination." 5

The Bill died in the 2014 election, when the PQ was defeated by the Quebec Liberal Party. Nevertheless, the debate on the place of religion in the public space continued to rage. In October 2017, Quebec's National Assembly successfully passed Bill 62, "An Act to foster adherence to State religious neutrality and, in particular, to provide a framework for requests for

\footnotetext{
${ }^{4}$ CBC News, "Violence against Muslim women on the rise, group says", Oct 2, 2013, http://www.cbc.ca/news/canada/montreal/violence-against-muslimwomen-on-the- rise-group-says-1.1876564

${ }^{5}$ Catherine Solyom, "Charter: Quebec HRC in complete opposition to the government, chairman says", The Gazette, November 4, 2013, http://www.montrealgazette.com/life/Charter+Quebec+complete+opposition+go vernme nt+chairman+says/9119479/story.html
} 
accommodations on religious grounds in certain bodies." ${ }^{6}$ In effect, the law prohibits Muslim women who wear facecovering apparel from receiving or providing public services including receiving medical treatment or riding public transportation.

This thesis project is rooted in the research that I conducted years ago, when I was pursuing a $\mathrm{PhD}$ in Communication Studies at Concordia University, in Montreal. I entered the program in 2012, at the same moment the PQ was elected. The political atmosphere of the time, and what I perceived as blatant racism in the government's discourse, prompted me to focus my research on questions of secularism (and its French form, laïcité), nationalism, racism - particularly what philosopher Etienne Balibar has called "neo racism" or "racism without race"7 - religious material manifestations in the public space, and the policing of the bodies that inhabit that space.

For Balibar, racism is the act of differentiating and classifying human beings into distinct categories, following a mental process that consists in identifying difference, which implies an

${ }^{6}$ http://www.assnat.qc.ca/en/travaux-parlementaires/projets-loi/projet-loi-62-411.html

1. Balibar first wrote about neo-racism in Balibar, Étienne. 1988. "Y a-t-il un néoracisme?". Race, Nation, Classe. Les identités ambigües. Éditions La Découverte, pp. 27-41. 
act of self-identification and of identification of otherness, and necessarily entailing the exclusion of certain social groups ${ }^{8}$. From this perspective, what Balibar calls 'neo-racism' is, as a product of the postcolonial era, less based on the idea of race as a biological given; rather, it is shifting the rhetoric to questions of so-called "cultural differences" and tend to prompt discussions about immigration and assimilation to the "host society." By presenting ethnic characteristics as universal and immutable and by raising the spectre of a possible "corruption" or "pollution" of said characteristics, these discourses are ensuring the maintenance of racial segregation, both ideologically and in practice ${ }^{9}$.

This project is a reflection on the role of narrative in spatial imagination and design. It invites the reader to follow me, a non-Muslim woman who was born and raised in Montreal, as part of a journey in search for the Islamic spaces of my city. In this place that I call home, resides an unfamiliar landscape; a city I had only heard of before I started my own investigations and explorations. Through the interpretation of 5 selected narrative themes - visibility, movement, opacity, threshold, and façade - embodied in 5 mosques dispersed on the island, I describe 5 chosen aspects of Islamic places of worship. As an

${ }^{8}$ Balibar, 1997, pp. 32-33.

9 Balibar, 1997, p. 28. 
auto-ethnography of sorts, this project allows me to deconstruct and re-construct a set of interpretations of the forms, events and qualities of these buildings and the landscape they make and occupy.

How can traditional architectural means of representation photography, models and drawings - contribute to make a hidden landscape appear? Through an exploration in narratives and techniques of representation, and through itineraries embroidered in the urban fabric of the city of Montreal, this thesis explores this presence of a city within the city, a city that longs for recognition, for illumination. 
Part I : Context 


\section{History}

The Charter of Quebec Values debate followed a decade of political uncertainty and social unrest regarding immigration policies in Quebec, and more specifically, the management of a more visible religious immigration to the province. As sociologists Annick Germain and Julie Elizabeth Gagnon note, "as immigrants come from an extremely diversified array of countries, especially in Toronto and Montreal, ethno-cultural diversity is a familiar and well-accepted feature of Canadian society. ${ }^{10}$ Nevertheless, even though religious diversity is one expression of this ethno-cultural diversity, it is one that has been particularly problematic in Quebec ", a fact that is mainly attributable to the province's markedly different history with organized and visible religion compared to the rest of Canada. Quebec's religious past is not only extremely rich, it is also an integral part of today's national identity, and the contemporary quasi-disdain of religion can in part be explained by the Catholic Church's civic and social omnipresence and omnipotence until the 1960s.

Quebec is indeed the only Canadian province to have experienced la Révolution tranquille - the Quiet Revolution - a period of intense

\footnotetext{
${ }^{10} 2003$, p. 298

"See Wells, Paul. “Jagmeet Singh's Quebec problem.” Macleans.ca, July 11, 2017. Accessed November 3, 2017, http://www.macleans.ca/politics/ottawa/jagmeetsinghs-quebec-problem/
} 
social, political, and cultural change that began in 1960 and that, in approximately 10 years, witnessed the secularization of government, the creation of a welfare state, the realization of the province's economic independence through nationalization of its natural resources, and the rise of a pro- French and pro-sovereignty movement. ${ }^{12} 13$

The Quiet Revolution followed a period known as la Grande Noirceur - the Great Darkness - that lasted from 1936 to $1959^{14}$ during which Quebec conservative premier Maurice Duplessis had the active support of the Church. His government is remembered for its anti-union laws and its lack of investment in social services, but first and foremost for its patronage and corruption, to which the Church turned a blind eye in order to maintain its absolute power. Social elites, the Church and the provincial government formed an extremely powerful triumvirate that was strongly opposed to the winds of social change buffeting the Western world after World War II.

\footnotetext{
${ }_{12}^{12}$ Germain and Gagnon, 2003, p. 300

${ }^{13}$ This linguistic nationalist movement can partially be explained by the fact that, until that time, the majority of Francophone Quebec workers had lived below the poverty line, and Francophones could generally not join the executive ranks, because most businesses were owned and managed by unilingual Anglophones. ("Francophone-Anglophone Relations," TheCanadianEncyclopedia.ca, 2018).

${ }^{4}$ Duplessis' leadership was interrupted from 1939 to 1944 by a Liberal government. In less than five years, more progressive measures were implanted, like the improvement of the public pension plan, the establishment of compulsory elementary education, the nationalization of energy and creation of Hydro-Quebec, and gaining women the right to vote.
} 


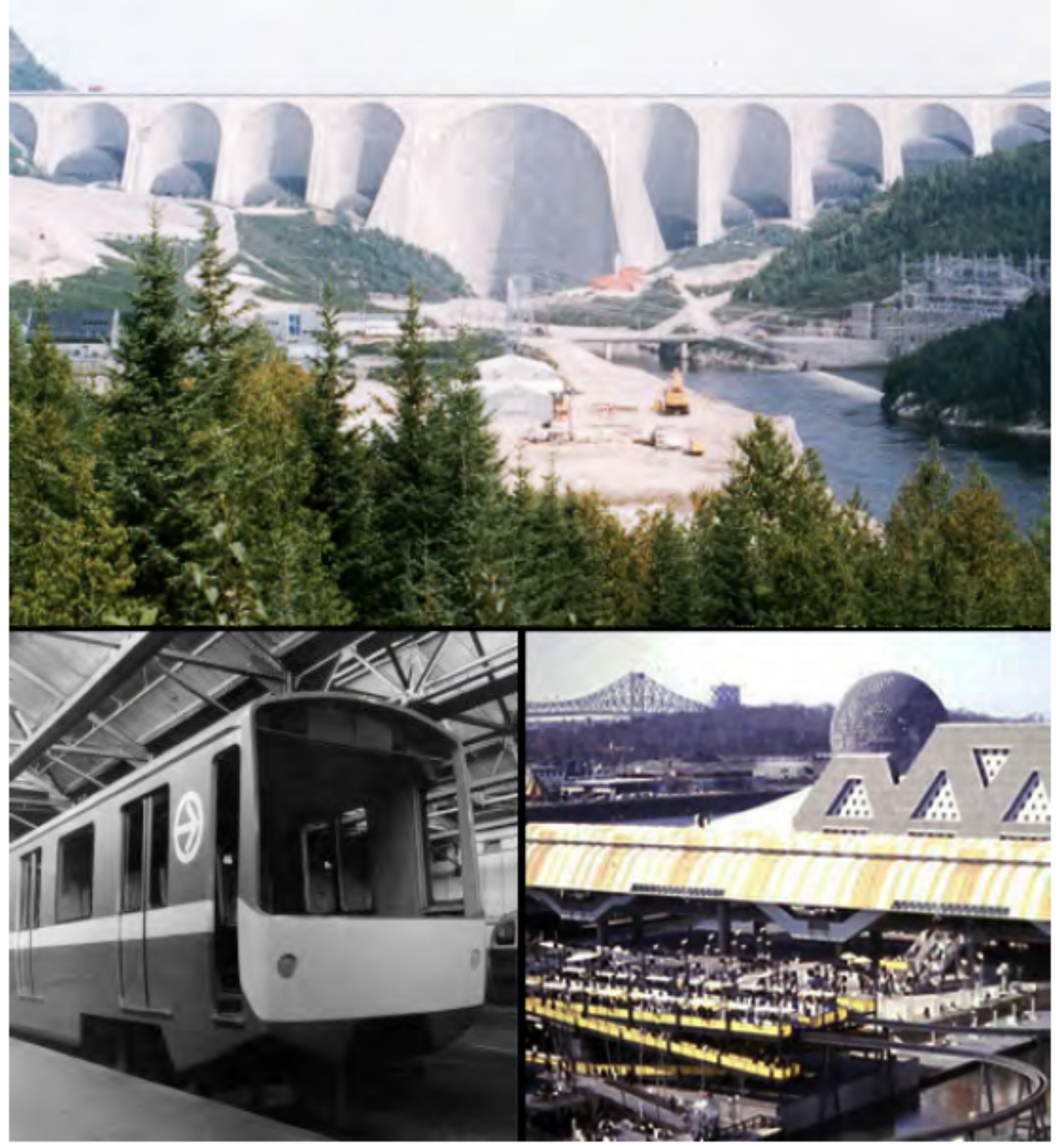

Figure 1: Emblems of the Quiet Revolution: the Manic-5 hydroelectric plant, the Montreal subway, and the 1967 International and Universal Exposition

To this day, as Marie McAndrew (Canada Research Chair on Education and Ethnic Relations) writes, the Quebecers who are 
of French-Canadian origin "have a specific and usually more negative relationship with religion than people in the rest of Canada," because "for most people born before the 1960s, in fact, the association between religion and public space evokes bad memories or at least memories that are incompatible with their democratic ideals. ${ }^{\text {15 }}$

In the mid 1990s, when the provincial government adopted an active strategy to increase the number of Francophone immigrants, Quebec became - and still is - the Canadian province that welcomed the most Muslim immigrants. This group alone has "accounted for nearly $40 \%$ of the flow in recent years, which, in the post-September 11 context, has had the effect of making the issue of religious diversity more visible. ${ }^{p 16} 17$ This is where the past alliance between the government and the religious authorities comes into play, being referenced by numerous pro-laïcité groups when they want to flag a situation in which the gains of the Quiet Revolution - especially the equality between men and women ${ }^{18}$ - could be jeopardized. As Germain and Gagnon put it,

\footnotetext{
${ }_{16}^{15} 2012$, p. 61.

16 ldem.

${ }^{17}$ It is nevertheless important to specify that not all Muslims in Quebec are immigrants, and that the first Islamic organization in Quebec was founded in 1954.

${ }^{18}$ Quebec was the last Canadian province to grant women the right to vote. This is in great part explained by the fact that the French-speaking suffragette movement was hobbled by the opposition of the Catholic Church and by
} 
In the reconstruction of the Quebecois identity, secularity is now one of the cornerstones of the new discourse on identity. It was in this particular context that 'the unexpected other' presented himself, as an immigrant asking for the recognition of his religion and his collective identity in public space, leading to very real challenges with regard to co-existence.

\begin{abstract}
The recent recurring debate on reasonable accommodation ${ }^{20}$
has contributed to a rise in political tensions, prompting the Liberal government to appoint in February 2007 the Consultation Commission on Accommodation Practices Related to Cultural Differences, also known as the Bouchard-Taylor Commission.
\end{abstract} After 3 months of conducting hearings in 16 Quebec regions, the commission submitted their final report in May 2008.

nationalist fears: "The insertion of the word male [...] in 1849 into Québec election law reflected an emerging ideology that placed women and men in separate spheres. This reflected the increased idealization of women as guarantors of cultural survival, who had no place in political life. Under this ideology, women were expected to remain at home, producing children and guaranteeing culture. As French Canadians increasingly became a minority culture among Englishspeaking Protestants in British North America, women's suffrage was seen as a particular threat to their national survival." ("Women's Suffrage in Canada," TheCanadianEncyclopedia.ca, 2018)

192003 , p. 314.

${ }^{20}$ The first extensive coverage of religious accommodations related issues in Quebec's news media dates back from 2006 and 2007, leading to the conservative ADQ party forming the official opposition in the provincial legislature 2007 to 2008 . The extreme attention given to these events created rise in political tensions that can be described as follows: "Among the most problematic elements in the media treatment and even more so in people's reactions, we can especially point out the use of non-inclusive and polarizing language (us/them), the nearly exclusive association of reasonable accommodation with immigrant integration and the tendency to associate voluntary adjustment or simple agreement among neighbours with reasonable accommodation in the legal sense imposed by the Canadian constitution" (McAndrew, 2012, p. 62) 
In their 310 page long report, the Commission discussed at length accommodation practices in health and education, but as Annick Germain deplores, “municipal issues, urban planning, and the allocation of urban space were barely mentioned," ${ }^{21}$ and the report remained silent on the issue of places of worship.

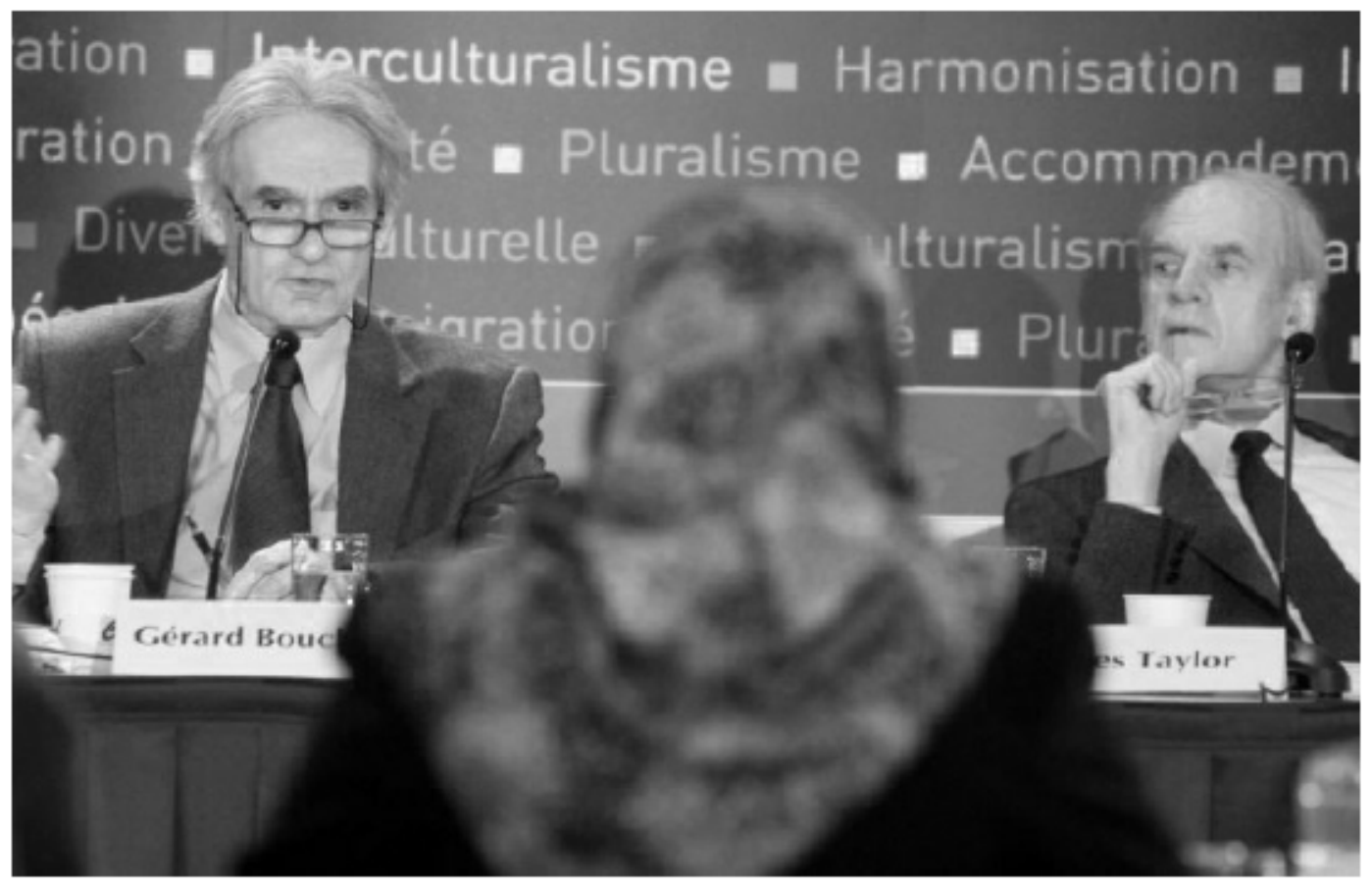

Figure 2: Gérard Bouchard and Charles Taylor, co-Chairs of the Consultation Commission on Accommodation Practices related to Cultural Differences

The debate, Germain writes, "ultimately revolved around the 'neutrality of public space' and the belief that religious practice

${ }^{21}$ Germain 2010, p. 89. 
should be confined to private places (or spaces) of worship.." As we will see below, this understanding of secularism presupposes that the only way for differences to co-exist peacefully is to provide a so-called "neutral" public space, a space that would be devoid of any religious character or marker of religious identity.

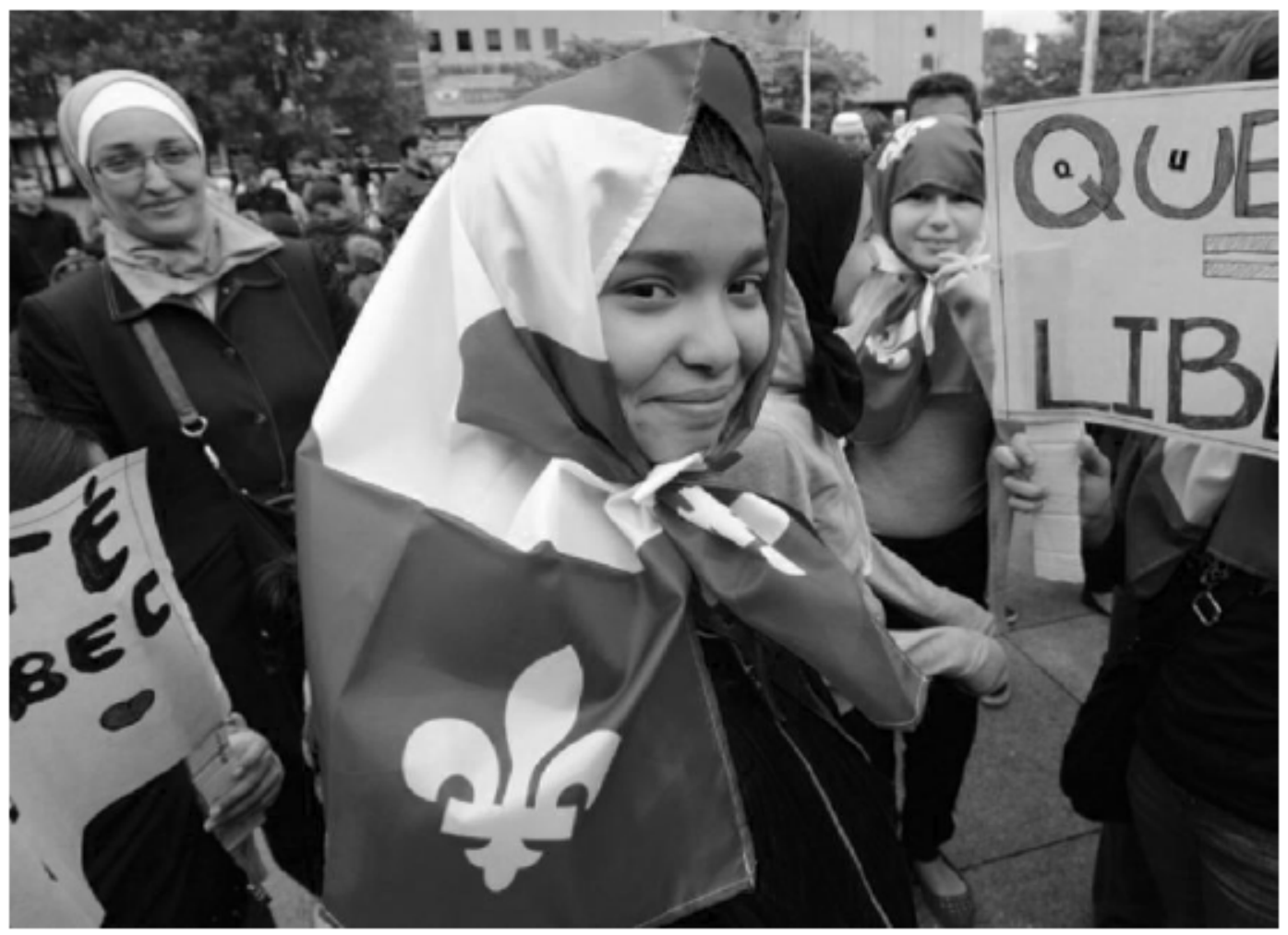

Figure 3: Woman donning Quebec's flag at a protest against the Charter of Quebec
Values

${ }^{22}$ Germain 2010, p. 90. 


\section{Secularism}

If the State is neutral, then every person who represents the State must embody this neutrality. ${ }^{23}$

The secularity of the State and its so-called nemesis, the alleged "return of the religious," ${ }^{24}$ are recurring themes in La Belle Province, especially since the first debate on reasonable accommodation, when a series of highly-publicized anecdotes exacerbated a budding racist and xenophobic discourse targeting Muslim, Jewish, and Sikh communities. ${ }^{25}$ In this narrative, religious values were presented as a direct threat to the "Quebec values," values that are supposed to be the cement that holds together one coherent culture.

According to anthropologist Saba Mahmood, secularism is broadly understood "as the separation between church and state, religion and law, and ecclesiastical and political authority" ${ }^{26}$ and is sometimes presented as what happens de facto when religion and religious ideology are "evacuated" and "taken out"

\footnotetext{
${ }^{23}$ Gouvernement du Québec, "Parce que nos valeurs, on y croît," official government document, September 2013.

24 According to religious studies scholar and author Louis Rousseau (2012), there is no such thing as a "return of the religious" in the public sphere. Rather, religious diversity in Quebec tends to manifest itself more visibly in city centres, and the recent arrival of immigrants coming from a larger number of countries only increase the number of religious identity markers.

${ }^{25}$ Monika Kin Gagnon and Yasmin Jiwani have written extensively on the subject, and a detailed timeline of the events can be found in "Amplifying Threat:

Reasonable Accommodations and Quebec's Bouchard-Taylor Commission Hearings."

2015, p. 2.
} 
of the public realm. However, it is in fact a modern ideology that emanates "from the structure of the modern liberal state, which promises to demolish religious hierarchies in order to create a body politic in which all its members are equal before the law." ${ }^{27}$

In reality, says Mahmood, "its claim to religious neutrality notwithstanding, the modern state has become involved in the regulation and management of religious life to an unprecedented degree, thereby embroiling the state in substantive issues of religious doctrine and practice." 28 According to a growing body of scholarly work ${ }^{29}$, the modern secularist ideology takes its roots in Christian societies, where the cut between the pious life and the lay life has been inscribed in the founding texts from the very beginning. Being a Christian monk or taking the Christian path to "perfection" equated renouncing the realm of laity (marriage, work, and so on) and taking the three evangelical counsels that are chastity, poverty, and obedience. Among Christians, as opposed to Protestants or Orthodox Christians for example, the Catholic Church chose to maintain this discipline, and members of the Catholic clergy are thus very clearly separated from their parishioners - which is not the case in many other religions, including Islam. The distinction

\footnotetext{
${ }_{27}^{27}$ Mahmood, 2015, p. 2.

${ }^{28}$ Idem.

${ }^{29}$ Asad, 2003; Calhoun et al., 2011; Scott, 2007; and Taylor, 2011, among others.
} 
between the private and the public religious sphere is a Western Christian product, one that manifests itself in terms of opposed binaries: you are either inside the lay world or outside.

Therefore, as Mahmood explains, the secular "is not the natural bedrock from which religion emerges, nor is it what remains when religion is taken away" ${ }^{30}$ but is rather a new conception of "self, time, space, ethics, and morality, as well as a reorganization of social, political, and religious life" ${ }^{31}$. In practice, this presumed difference "between religious practice (public) and religious belief (private) continues to justify state sanctions against minority religious symbols and practices in the public sphere." ${ }^{32}$

In other words, "the question of how and where to draw the line between religion and politics, between what is deemed public and private, acquires a particular salience in liberal polities and is constantly subject to legal and political contestation." ${ }^{33}$ Unsurprisingly, secularity as understood by the French majority in Quebec seems to be directly related to its Catholic heritage and way of perceiving the religious realm in these terms.

\footnotetext{
${ }^{30}$ Mahmood 2015, p. 3

${ }^{31}$ Idem.

${ }^{32}$ Mahmood 2015, p. 9

${ }^{33}$ Mahmood 2015, p. 4
} 


\section{Hatred}

As a direct consequence of this rejection by the majority of Quebec society of certain values that are deemed "religious," Muslim women choosing to cover their heads have recently been labeled, in the francophone mass media, as "crazy" by director Denise Filiatrault ${ }^{34}$, and "sado-masochistic" by lawyer and author Wassyla Tamzali ${ }^{35}$. This is neither new nor very surprising. As argued by Edward W. Said, there is a long Orientalist tradition that victimizes veiled women and that demonizes their masculine Muslim counterparts ${ }^{36}$. But, as activist Leila Bdeir expresses in her essay In the Name of Equality?, these very women are now said, instead of being threatened themselves, to be threatening the secular nature of Quebec: "No longer are Muslim women only perceived as dangers to themselves, but they are now perceived to pose a threat to the Nation as well. Why otherwise would la Charte de la laïcité become known as la Charte des valeurs québécoises?"37

Moreover, the wariness towards Muslim communities manifests itself in the most recent statistics regarding hate crimes in Canada. According to Statistics Canada, the number of police-

\footnotetext{
${ }^{34}$ Bellerose, Patrick. "Denise Filiatrault: les femmes qui disent porter le voile par choix sont «des folles»." HuffingtonPost.ca, October 15, 2013.

${ }_{35}$ Proulx, Marie-Hélène. "Laïcitê: non au voile." Chatelaine.com, December 2, 2013.

${ }^{36}$ See Said, Edward W. Orientalism. Pantheon Books, 1978.

${ }^{37}$ Bdeir, Leila. "In the Name of Equality?" dawsoncollege.qc.ca, November 13, 2013.
} 
reported hate crimes targeting Muslims increased 253 per cent countrywide from 2012 to $2015^{38}$. As for the province of Quebec, hate crimes targeting Muslims slightly decreased in 2016 (16 fewer incidents) but 10 more crimes targeting Arabs and West Asians were reported ${ }^{39}$. The numbers for 2017 were yet to be published at the time of writing.

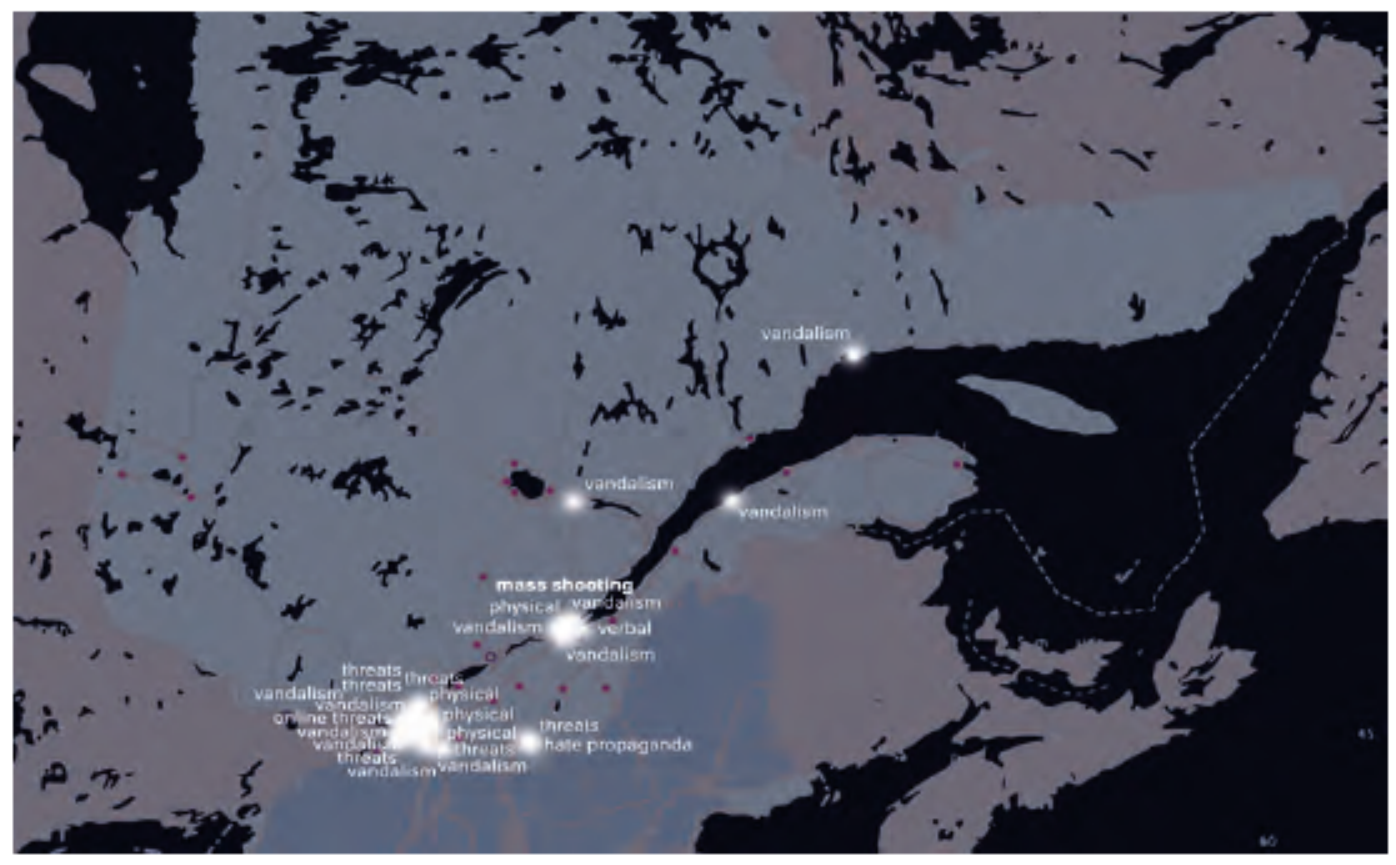

Figu re 4: Hate Crimes in Quebec, 2013 - 2017

\footnotetext{
${ }^{38}$ Minsky, Amy. "Hate crimes against Muslims in Canada increase 253\% over four years." Globalnews.ca, June 13, 2017. Accessed October 3, 2017, https://globalnews.ca/news/3523535/hate-crimes-canada-muslim/ Statistics Canada. "Police-reported hate crime, 2016." Statcan.gc.ca, November 28, 2017. Accessed December 1, 2017, https://www.statcan.gc.ca/dailyquotidien/171128/dq171128d-eng.htm
} 


\section{Space}

Space is an integral part of our embodied experience. Yet, we often overlook what it means, particularly when discussing "religious space" and "secular space." As a point of departure and reflection, we might ask: what exactly is space?

A common assumption, an inheritance of the Enlightenment idea of space as a "container," is that architecture is created by the act of carving space out of space, of making something happen within an existing void. But this way of thinking about space presupposes a hollowness, whereas space, religious studies scholar Thomas Tweed argues, "is not an absence waiting for a presence. It's not undifferentiated vacuity, a void to be filled. It's not static or outside of the flow of time. It's not self-contained or beyond the flow of causes." ${ }^{40}$ Instead, what we call "space" is directly related to human experience, and is therefore charged with meaning. It could never be a void, as Henri Lefebvre argues in his The Production of Space, because space is not a naturally eternal topos; it is rather a product. Space, Lefebvre argues, is unequivocally social: "[Social] space is a [social] product" ${ }^{\mathrm{n1}}$, a product "conceived not as a completed reality

\footnotetext{
${ }^{40}$ Tweed 2011, p. 117.

${ }^{41} 1991$, p. 26.
} 
or an abstract totality, but as a set of possibilities in the process of being realized. ${ }^{42}$

\section{Sacred Space}

To paraphrase religious studies scholar Jeanne Kilde, sacred space is first and foremost experiential: humans fabricate the meaning, sacralize some spaces; "set them apart by doing certain things to them. ${ }^{43}$ Echoing this position, Thomas Tweed writes that religious spaces are understood as "imaginatively figured and/or sensually encountered locales that are deemed more or less 'special,' 'singular,' or 'set apart'."44 Religious spaces are "specific locales," 45 what Tweed calls a "differentiated" space. These spaces don't have to be "real," "authentic," they don't even have to have been experienced, "since the never-experienced contours of a desired terminus (Christ's heaven or Amida's Pure Land) or a distant territory (Jerusalem or Mecca) might orient daily life and elicit affective response more than tangible sites nearby." ${ }^{46}$

Tweed also argues, like Lefebvre, that spaces are "processes, not things." ${ }^{47}$ Therefore, religious spaces are "kinetic," because their nature is not fixed: "propelled along by natural-cultural flows, they

42 2008, p. 134.

43 Kilde, Jeanne H. “Sacred Space and Contested Terrain." TEDxUMN 2012.

44 Tweed 2011, p. 119.

45 Tweed 2011, p. 118.

${ }^{46}$ Idem.

47 Tweed, 2011, p. 120. 
change over time." ${ }^{48}$ This intertwining of the spatial and the temporal is the founding element of the materiality of religious practice.

Worship spaces are also inevitably "interrelated", as they necessarily connect to other sites, events, and/or concepts. In the case of Montreal mosques, these interconnections can take the form of various bounds, like ethnicity (Maghreb, Mashrek, SouthAsia, etc.) or shared language (French, English, or other); it can also be based on the belonging to a branch (Sunniism, Shiism) or a school (Sufism, etc.). These spaces can also be "linked with domestic spaces and childhood memories" ${ }^{49}$ when the devotees grew up with specific objects, texts or images in their home. In other words, sacred space "opens out to other times and wider spaces $^{\mathrm{m5}}$ and can propel the devotee in time and space, back to other loci imbued with religious meaning.

Finally, religious spaces are both "generated" and "generative," in the sense that they both participate in the making of, and are being made by, other spaces or practices. Even though its physical existence cannot be denied, a space is generated by and comes into being "through embodied perception, figurative imagination,

\footnotetext{
48 Idem.

${ }_{50}^{49}$ Idem.
} 
and ritual practice." ${ }^{51}$ In other words, "special spaces [...] are always both "natural" and "cultural" sites, always more than the stuff [...] that forms and decorates them. ${ }^{n 2}$ When they generate, they leave an impression, they "do" something to the person who interacts with them. "We might say playfully," Tweed writes, "that spaces are people too. [They] are structures that exert agency." ${ }^{53}$ So whether a person attends the Friday prayer in their local newly renovated mosque or stops by the interfaith space at the airport before they catch their flight, "it becomes clear that space - and special spaces of many kinds and multiple scales - are important for the pious, who make the spaces that, in turn, make them. ${ }^{54}$

To conclude, the bodily experience is of prime importance in the human perception and conception of space: "as the image of the kneeling devotee reminds us, the confluence of organic-cultural flows - and spatial orientation - always begins with bodies, biologically constrained and culturally coded selves. The 'sensory cultures' [...] are co-produced by embodied selves interacting with sensorial environments encountered through sound, touch, smell, and sight." ${ }^{55}$ It is thus important to note that bodily markers, such as gender and race for example, undoubtedly impact the way in which

${ }^{51}$ Tweed, 2011, p. 121.
52 Tweed, 2011, p. 122.
53 Idem.
${ }^{54}$ Tweed, 2011, p. 123.
55 Tweed, 2011, p. 122. 
one situates themselves relatively to their own body, to their home, to their homeland, and to the cosmos.

\section{Public}

Public spaces are traditionally defined by urban planners as tangible physical spaces that are open and universally accessible, like streets, parks, and public squares. They are generally conceptually opposed to private spaces, which belong and are accessible only to an individual person or a specific group. But the notion of "public space" involves, as a corollary, the "public" in the broader sense of the term.

As it has been highlighted by anthropologist Talal Asad and social theorist Michael Warner among others, not everyone has the same access to the "public sphere," nor do they have the same level of visibility or authority when they take part in the public debate. That is because for a public to be constituted, the attention of one person or more needs to be fixated onto something ${ }^{56}$. Attention, however, is subjective:

[The] enjoyment of free speech presupposes not merely the physical ability to speak but to be heard, a condition without which speaking to some effect is not possible. If one's speech has no effect whatever it can hardly be said to be in the public sphere, no matter how loudly one shouts. $^{5}$

${ }^{56}$ Warner, 2002, p. 60.

${ }^{57}$ Asad, 2003, p. 184. 
The question of who constitutes the public is therefore paramount: "If the performance of free speech is dependent on free listening, its effectiveness depends on the kind of listener who can engage appropriately with what is said. ${ }^{258}$ This also means that the authority of whoever might join the debate will necessarily be dependent on the public ability - or willingness - to acknowledge that person's presence. In the words of social psychologist Serge Moscovici, "invisibility is not due to any lack of information conveyed to the eyeball, but to a pre-established fragmentation of reality, a classification of the people and things which comprise it, which makes some of them visible and the rest invisible.. ${ }^{59}$ Everything seems to be, following the adage, in the eye of the beholder.

\section{Visibility}

As Annick Germain explains in her essay Religion in Public Space in a Multi-Ethnic Environment, visibility (or the lack thereof) is a significant concern for many minority groups:

Some minorities prefer to remain inconspicuous (for example, by locating their place of worship in a vacant commercial plaza with no exterior signage); others, however, prefer to communicate the symbolic importance of their place of worship (with their buildings and their architecture) and to stake their place in the city.

\footnotetext{
${ }^{58}$ Asad, 2003, pp. 184-185.

59 2000, p. 19.

60 2010, p. 90.
} 
Far from being the sign of an internal anguish regarding the group's identity and a refusal to integrate into the "host" society, what Germain calls the "ethnic branding of space" ${ }^{61}$ is a way for ethnoreligious groups to "make their mark on their local urban landscape and garner attention for their civic contribution. ${ }^{n 62}$ As Karla Britton writes in the introduction of Constructing the Ineffable: Contemporary Sacred Architecture,

... contemporary sacred spaces [...] such as landscapes,
monuments, and museums [usually] evoke great
commitment, pathos, and sacrifice on the part of a
community of individuals. In this respect, religious
buildings and sacred landscapes rarely function simply as
isolated expressions of largely sectarians experiences.
Rather, these sacred spaces often contribute in critical
ways to shaping the larger cultural and urban fabric of
contemporary life. 63

The desire to leave a trace of their presence in the urban is often a call for recognition. Refusing to acknowledge or denying the minority group this recognition through visibility is equivalent to denying its worth and contribution to society.

Making a minority group invisible is, for philosopher Axel Honneth, "an especially subtle form of racist humiliation," ${ }^{64}$ for "it demands gestures or ways of behaving that make clear that the other is not

\footnotetext{
${ }_{62}^{61}$ Idem.

62 2010, p. 91.

${ }^{63} 2010$, p. 10.

${ }^{64}$ Honneth, 2001, p. 111.
} 
seen not merely accidentally, but rather intentionally." ${ }^{65}$ "Cultural history offers numerous examples of situations in which the dominant express their social superiority by not perceiving those they dominate," ${ }^{66}$ and recognition through social visibility is therefore the expression of the other person's supposed "social validity."

This desired invisibilization can be observed in many recent discourses regarding Muslim communities in the West, be it the debate on the Park51 Islamic community centre in New York City, the ban on minarets in Switzerland, or the more recent debate on the establishment of a Muslim cemetery in rural Quebec. At the same time, the hypervisibility of specific elements of the community contribute to a distortion in social representations. As sociologist Andrea Brighenti states, "power does not rest univocally with seeing or with being seen. Rather, it is the style in which seeing and being seen take place that carries the most important consequences. The exercise of power is always an exercise in activating selective in/visibilities." ${ }^{17}$

${ }_{66}^{65}$ Honneth, 2001, p. 112.

${ }_{67}^{66}$ Idem.

${ }^{67} 2007$, p. 339. 


\section{Power}

As we have seen above with Lefebvre and Tweed, space can be conceived as a bodily experience. We cannot think of the body as a generic thing or a blank slate, because it is necessarily marked by (more or less easily) readable markers of identity, such as gender and race. If the body is racialized, it then means that race, being an integral part of our bodily experience, will also be one of the fundamental determining factors in the way we experience space. As architect and scholar Craig Wilkins points out,

...space, as a critical element in the construction of identity and property, is racialized. The maintenance of this racialized space can currently be seen in the various ways state-authorized privatizations and policing of public space operate. [...] The seemingly "natural" decisions about space that authorize these and other biases spatial practices in the world are in actuality constructed on, legitimized by, and fundamentally invested in something equally naturalized but far less visible - whiteness - as the transparent and readily accepted requirement for desirable identity and spatial construction in our society.

Because of the inextricability of the body experience and the politics of space, "power [...] is embodied both abstractly and materially in the spatial organization of our built environment. ${ }^{69}$

${ }_{69}^{68}$ Wilkins 2007, pp. xv-xvi.

${ }^{69}$ Wilkins, 2007, p. xv. 
Whiteness, feminist theory scholar Sara Ahmed says, "orientates bodies in specific directions, affecting how they 'take up' space, and what they 'can do'. ${ }^{70}$ In this model, "race becomes [...] a question of what is within reach, what is available to perceive and to do 'things' with." ${ }^{71}$ Whiteness in Western societies is the default standard position: "whiteness is simply something one is; it is not analyzed, it is not felt, it is not a concern. It is base. Essential. It simply... is." ${ }^{\text {72 }}$ This implies that, as Ahmed puts it, "white bodies do not have to face their whiteness; they are not orientated 'towards' it" whereas "others appear only as deviants, or points of deviation..73

As a corollary of this obliviousness to prejudice against what does not pass as the norm, what Ahmed calls "white space" is "the repetition of the passing by of some bodies and not others. ${ }^{174}$ By that, she means two things: first, space is oriented around certain bodies. Of course, non-white bodies do inhabit white spaces, but "such bodies are made invisible when we see spaces as being white, at the same time as they become hypervisible when they do not pass, which means they 'stand out'

\footnotetext{
${ }^{70}$ Wilkins, 2007, p. 149.

${ }_{71}^{71}$ Wilkins, 2007, p. 154.

${ }_{73}$ Wilkins 2007, p. 11.

${ }^{73}$ Ahmed, 2007, p. 157.

${ }^{74}$ Wilkins, 2007, p. 159.
} 
and 'stand apart'."75 Second, bodies are oriented within this space, as "the effect of this 'around whiteness' is the institutionalization of a certain 'likeness', which makes nonwhite bodies feel uncomfortable, exposed, visible, different, when they take up this space. ${ }^{76}$

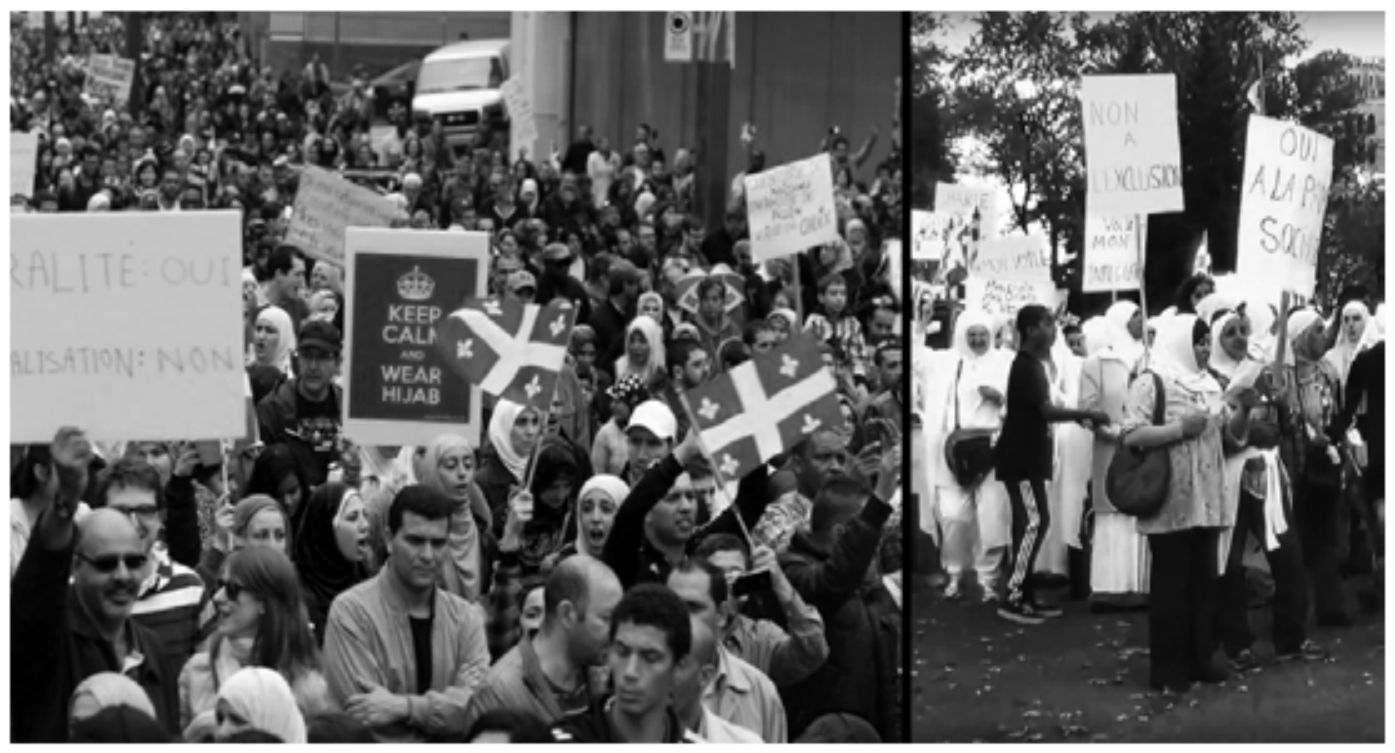

Figure 5: Protests against the Charter of Quebec Values in Montreal

75 Ahmed, 2007, p. 159.

${ }^{76}$ Ahmed, 2007, p. 157. 


\section{Mosques}

The focus of this research has never been to try to circumscribe what exactly is sacred in these buildings, nor is it to try to define what is religious and what is not. As the historian Barbara Daly Metcalf states, "for ritual, it is the practice, not the mosque, that matters." ${ }^{77}$ It is a fact that something happens in a certain space, and no matter what that "something" is, what is of interest here is the place where it happens. Mosques are extremely interesting in this respect, as they are often the site where the previously explored questions of sacredness, publicness, visibility, and power collapse.

\section{Mosques in Montreal}

Echoing the idea of the Ummah, or entire community of believers, the vast majority of mosques in Montreal are multicultural ${ }^{78}$. That being said, given the fact that there are larger ethnic groups than others, and that these groups are not all choosing the same neighbourhoods to live in, a group can sometimes constitute a de facto majority in certain mosques. When it comes to choosing a place of worship, people tend to attend Islamic centres that are

77 1996, p. 6.

${ }^{78}$ Rousseau 2012, p. 225. 
closest to their house or work place ${ }^{79}$, even though "increasingly, places of worship are serving a regional population base. ${ }^{n 0}$

Most Muslim communities integrate into their neighbourhoods without being the object of discontent or protests. However, they often must contend with zoning by-laws that can be discriminatory ${ }^{81}$, and in some cases boroughs are allowed to hold referendums for the citizens to approve or deny specific requests for official designation ${ }^{82}$.

Even if municipal regulations are not overtly targeting any religious or cultural minority in particular, they are, more often than not, articulated on the basis of a bias that favours the already existing read: Christian - spaces, such as churches, parvises, and the like. Montreal has for a long time been called la ville aux cents clochers - the city of a hundred spires - and the public spaces in front of these churches have helped to shape the perception and experience of the city. Indeed, by leaving the space in front of the

${ }^{79}$ Rousseau, 2012, p. 225.

${ }^{80}$ Germain 2010, p. 91.

${ }^{81}$ Among the most common concerns are parking and circulation issues, and protest from neighbours often prompts the authorities to become more stern when it come to the deliverance of permits. But as Germain and Gagnon mention, the traditional way of calculating the required number of parking spots should not be taken for granted. Indeed, "it is sometimes difficult to evaluate fairly the actual number of parking spaces required in relation to the number of seats in a building (as is usually done for churches), because a mosque, for example, generally does not have any seats since people sit on the floor" (2003, p. 305) 82 Shingler, Benjamin. "Decision to reject mosque in Ahuntsic not about Islamophobia, voters say." CBC News, June 7, 2016. Accessed January 22, 2018, http://www.cbc.ca/news/canada/montreal/ahuntsic-cultural-centre-mosquereferendum-1.3617932 
church open and by insuring it will always remain like this (by making it a park or a place, like the Place d'Armes ${ }^{83}$ ), urban planning and architecture have historically provided visibility, recognition, and free access to these spaces, with the guarantee that even urban densification would not alter the openness of the site.

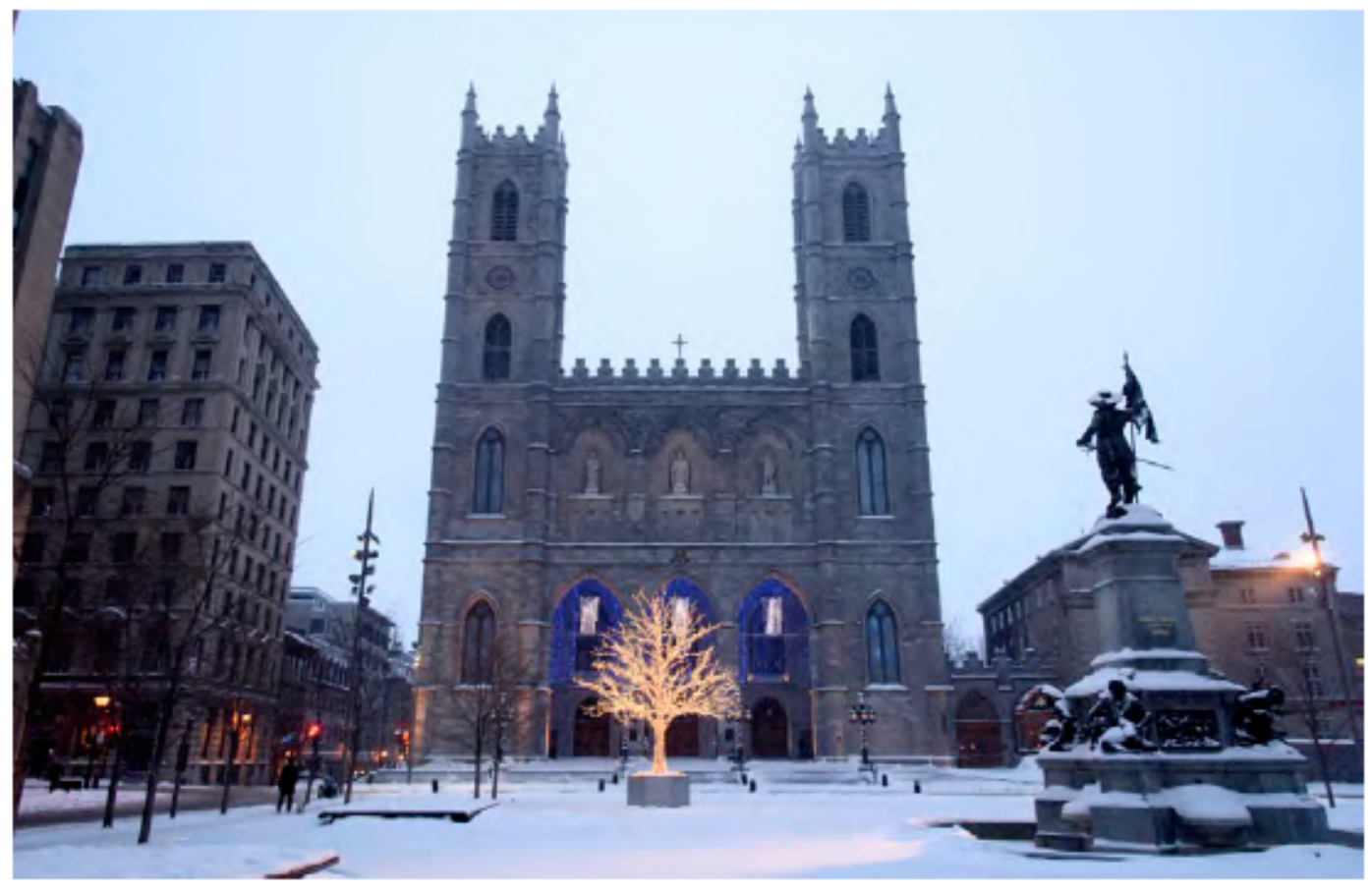

Figure 6: Place d'Armes in Montreal

${ }^{83}$ Establishing a Place d'Armes was an important way of marking the take-over of a land for French and Spanish colonizers. The Place still features to this day a monument in memory of Paul Chomedey de Maisonneuve, founder of the city, commemorating his defense of the French settlement against the native Iroquois. First developed in 1693 next to the foundations from the original Notre-Dame Church, the Place d'Armes is among the city's oldest public sites. The fact that it is also where state funerals are held shows how politics, national identity, and Christian history are inextricably intertwined in the symbolic of the Place d'Armes and the Notre-Dame Basilica. 


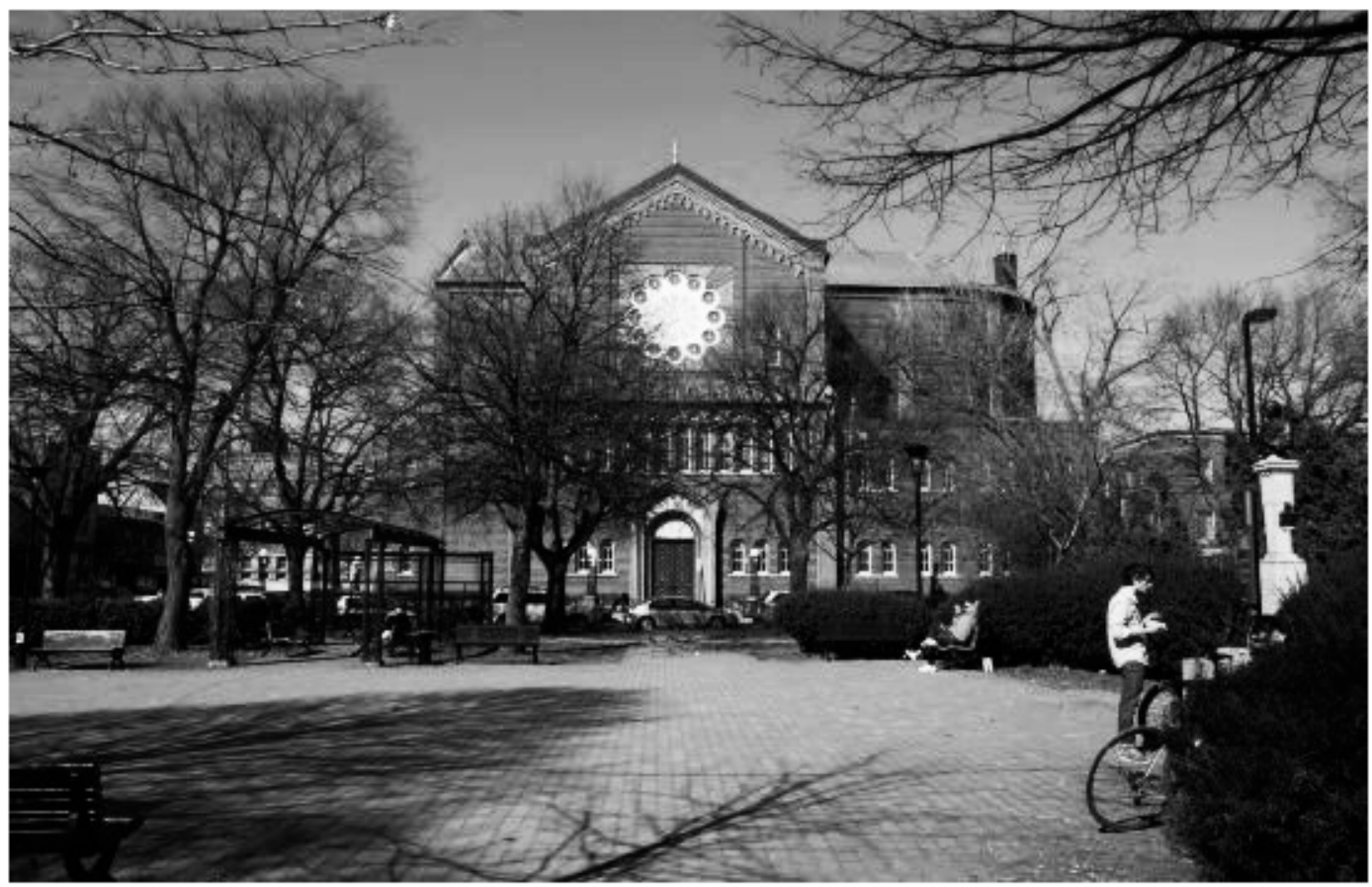

Figure 7: Church of the Madonna della Difesa

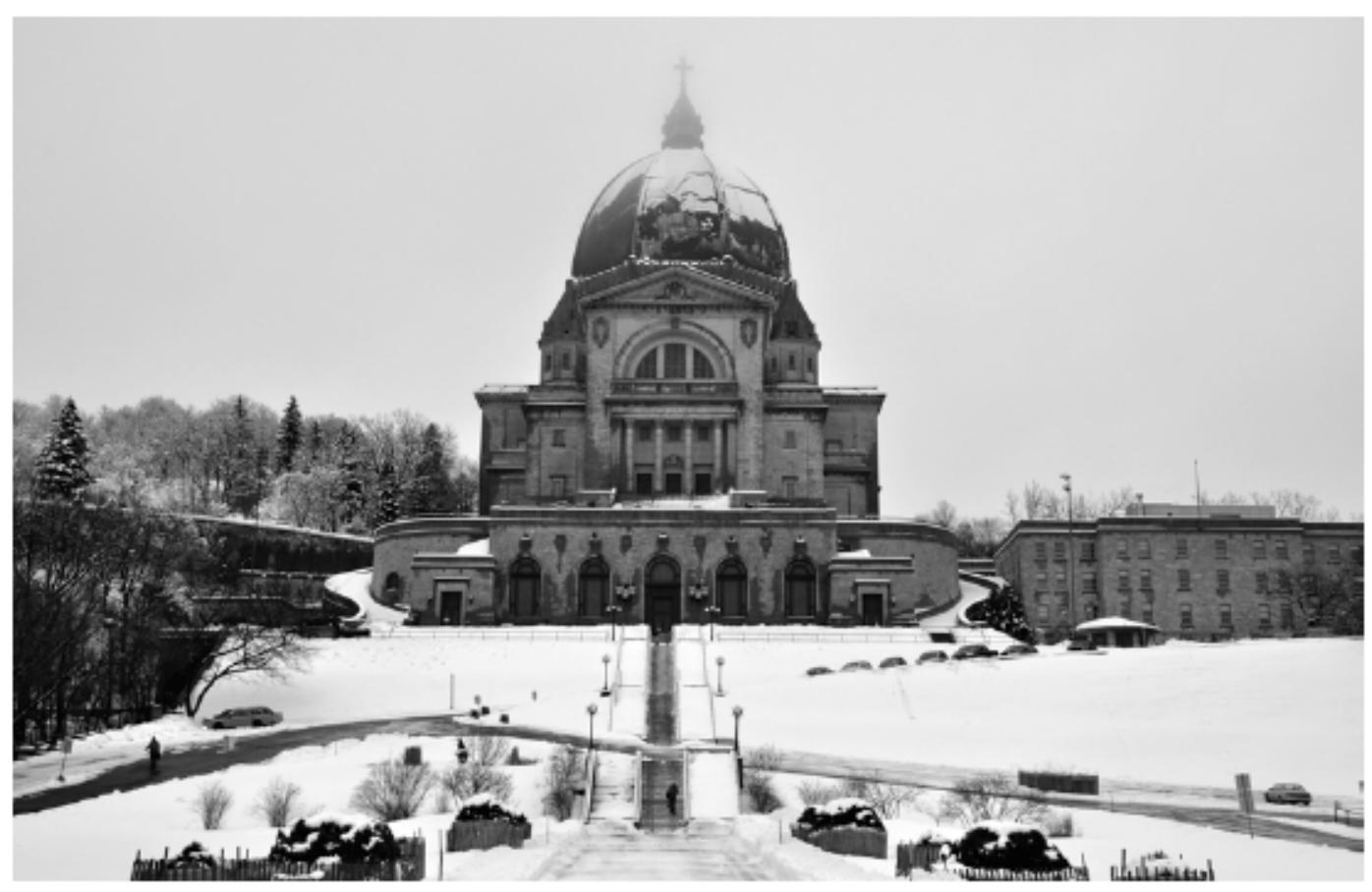

Figure 8: Saint Joseph's Oratory 
For historical, political, and economical reasons, most mosques in Canada do not enjoy the same privilege, and many of the Islamic spaces in Montreal often go unnoticed. Although it is allowed to build more "recognizable" mosques on the Island of Montreal ${ }^{84}$, most congregations choose, often motivated by financial considerations, to rent or buy an already existing building.

For example, it is common in densely populated neighbourhoods articulated around a big commercial artery, like Parc-Extension and the Little Maghreb, to find repurposed upper story spaces. These mosques are often situated above dedicated commercial spaces such as Halal restaurants or grocery stores. On the other hand, in more traditionally residential neighbourhoods like Rosemont and Villeray, it is more and more common to see duplexes that have been converted into mosques. However, no matter how they are repurposed, these spaces are envisioned with a great deal of attention toward design. They are of a particular interest because they constitute a fairly new type of repurposed vernacular architecture that has been turned into sacred space,

\footnotetext{
${ }^{84}$ Some municipalities define specific land use categories for places of worship, while others choose to adopt broader land use categories, like "collective or institutional facilities" for example. Montreal possesses its own charter and is not bound by Quebec's Cities and Towns Act. The city can therefore issue temporary permits authorizing a given land use despite existing zoning regulations (Germain and Gagnon, 2003, p. 303)
} 
and because the societal tensions that Muslim immigrants experience living in diaspora often have repercussions on the process of storefront mosque building.

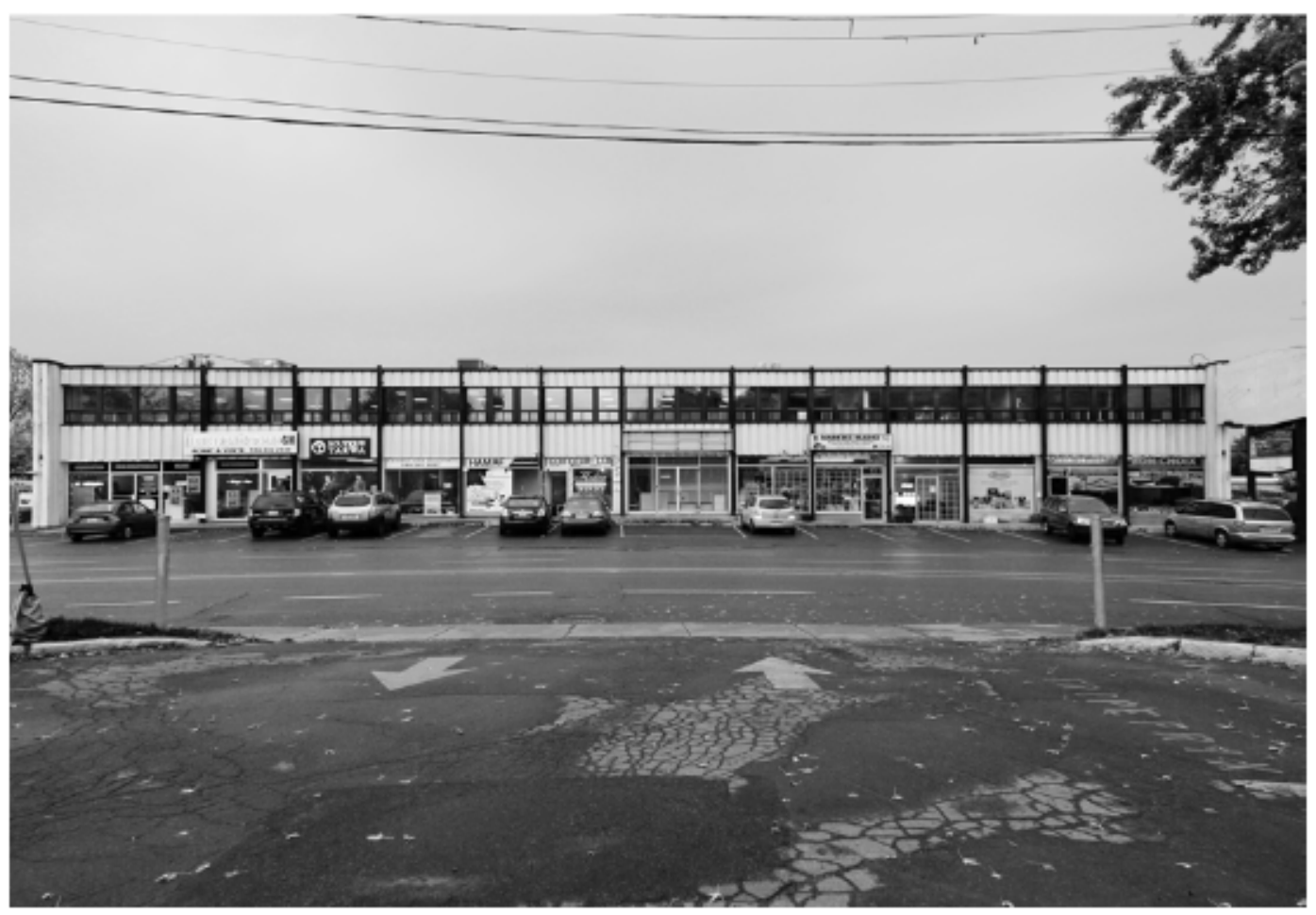

Figure 9: Madani mosque in Montreal. While still operating, the main entrance has been condemned, and some windows are barricaded with wooden boards. 


\section{What is a mosque?}

There is ongoing debate about the nature of the mosque, in Montreal as elsewhere. The correlation that we assume between Christian and Muslim places of worship requires a more critical unpacking, the latter encompassing a wide range of activities that could hardly be understood as "religious" in the Christian tradition.

Due to rigid zoning bylaws, not all mosques in Montreal fall under the "Convent, monastery, or place of worship" category ${ }^{85}$, and many of them are instead labeled as "charitable foundations," "social centres," or "Islamic centres," blurring (in nomenclature) the boundaries between religious and non-religious space. Many new places of worship built recently by immigrant communities are also "involved in helping individuals and families from the more fragile social categories (women, children and the elderly). ${ }^{n 66}$ For example, over the past few years,

... several congregations have tended to add community activities to their actual religious activities, thus making their places of worship more akin to a community centre. One example is the construction of a gymnasium for sports activities (in the case of a mosque in Saint-Laurent). Other places of worship already have classrooms devoted to language training or religious- education courses, communal kitchens (the Sikh Temple in LaSalle) or children's day-care facilities (the Coptic Church in Pierrefonds). These activities are occasionally open to the

\footnotetext{
${ }^{85}$ When granted the appellation, religious buildings are exempt from property and school taxes, following the provincial legislation on municipal taxation on places of worship. It is therefore extremely difficult for new congregations to obtain the permit.

${ }^{86}$ Germain and Gagnon, 2003, p. 299
} 
community as a whole. It then becomes difficult to draw a dividing line between the religious and secular spheres of activity.

Moreover, there exists "no formula of consecration or deconsecration of an Islamic site of worship, and historically mosque sites have been used, not only for praying, but for everything from doing business to levying troops. ${ }^{88}$

Some citizen accuse these communities of attempting to "fiddle with the words" to avoid having to comply with the law ${ }^{89}$, but it is important, in the light of the discussions above, to ask the question: can religious practice be confined to private space? According to Annick Germain, "most religions practice some collective rituals that spill over the boundaries of private space, and [...] most places of worship define themselves as public spaces." ${ }^{90}$ Islam, among other non-Western religions, often confronts the functionalist view of urban life "which presupposes a clear spatial distinction between different spheres of activities - some private, some public." ${ }^{11}$

${ }_{88}^{87}$ Germain and Gagnon, 2003, p. 306

${ }^{88}$ Metcalf, 1996, p. 6

${ }^{89}$ Caron, Steve. "Un centre communautaire aux allures de mosquée dans Mercier." Journalmetro.com, February 9, 2015. Accessed November 1, 2017, http://journalmetro.com/local/mercier-anjou/actualites/717673/prier-danslillegalite/

${ }_{91}^{90}$ Germain, 2010, p. 90

${ }^{91}$ Idem 


\section{Part II : Itineraries}




\section{Building the map}

Three different sources were used to build a map of the Islamic places of worship in Montreal: the Halal Map ${ }^{92}$, an online tool that identifies points of interest such as mosques, Islamic schools and halal restaurants; the website islammaps.com, a compendium providing "All Islamic locations at one place"; and Les mosquées de Montréa ${ }^{\beta}{ }^{3}$, a list compiled by the Montreal Naqshbandi Sufi Center. I created my own map by double-checking the informations in Google Street View, and then by inputting the data in an online map. The map was - and still is - a work in progress. To this day, I found 70 mosques, which is far from truly representative of the reality of this landscape. The ephemeral character of the most modest mosques makes it extremely difficult to state with certainty the exact number of Islamic places of worship.

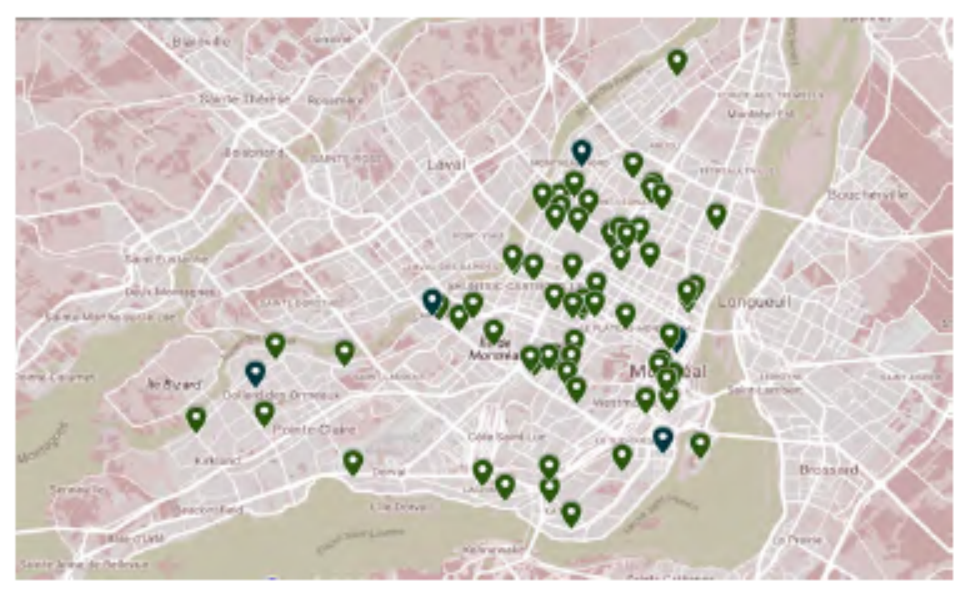

Figure 10: Map of some Islamic places of worship in Montreal

${ }_{92}^{92}$ http://www.elfath.ca/carte-halal/ (no longer accessible)

93 ttp://www.naqshbandi.ca/mtl/mosquees.shtml 


\section{Observations and questions}

While exploring the city, three points seemed particularly important. First, while certain mosques in this Atlas are designed with familiar shapes and share many distinctive formal qualities, few are newly built. Most of them are located in previously abandoned buildings, often industrial or commercial, sometimes residential, and many of them are "storefront mosques."

Second, I also noticed that many mosques had removed their signs, as if these communities were trying to be as discreet as possible. I couldn't tell if this was directly related to the upward trend in recorded racist and Islamophobic hate crimes, but I noticed a concerning number of traces of vandalism.
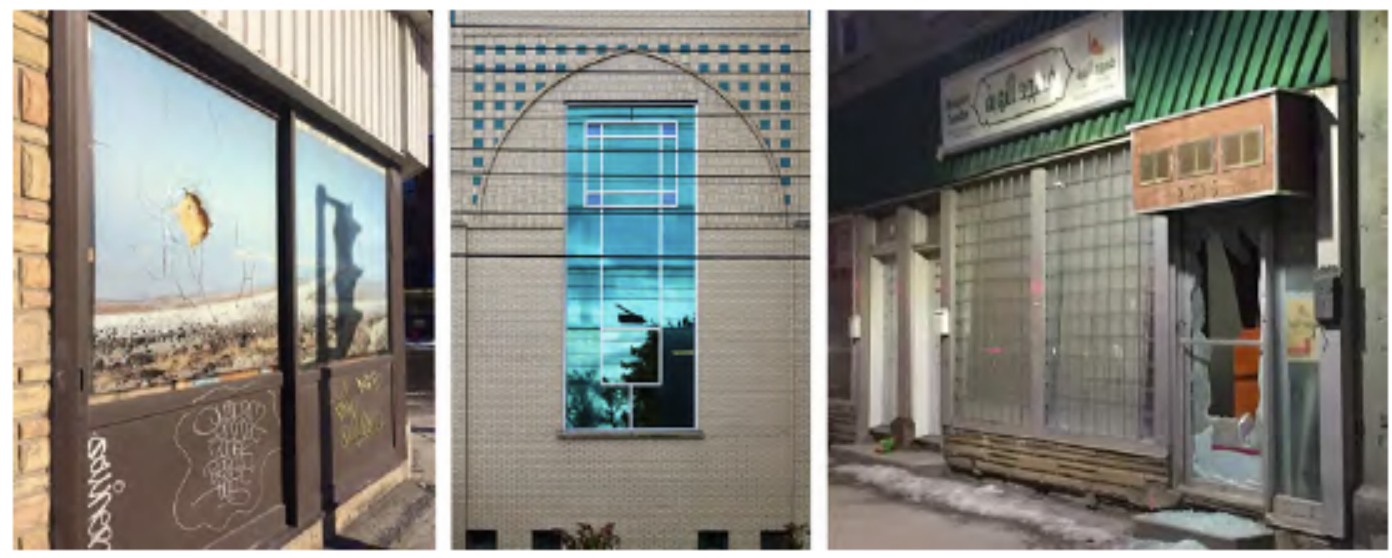

Figure 11: Broken windows 
Finally, zoning in Montreal does not allow for places of worship in private homes. I discovered, however, that some mosques had been established in one or two bedroom apartments in mid-rise apartment buildings. This raised some very problematic questions: what should I do with these mosques, should I include them in my atlas even though they contravened the bylaws? What if someone reads my thesis and decides to report those mosques? I decided to include the pictures but to blur the addresses, and to avoid providing any information that could harm the community that I documented.

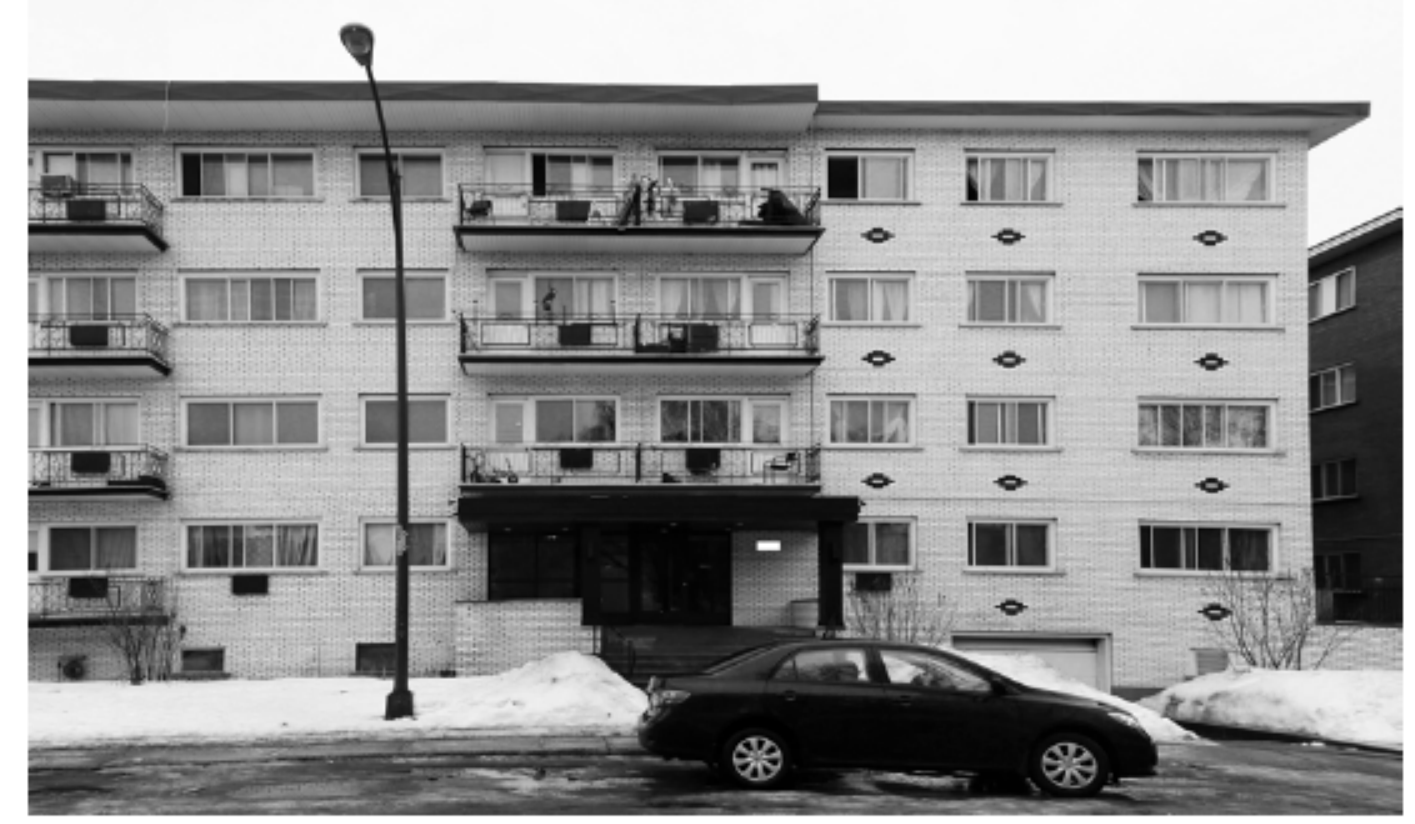

Figure 12: Mosque in an apartment building 


\section{Photography}

To stand before a photograph in the early twenty-first century is no longer simply to ask, What is this? What message is intended by this picture? First we ask, or ought to ask: Why am I here, standing before this picture? What do I expect from photographic experience and what part should lexpect to play? ${ }^{99}$

Mine is an outsider's perspective, and the chosen methodology tries to reflect that reality. The point of departure of the visual trajectories of this research was to photograph and document existing mosques in Montreal. Inspired by Bernd and Hilla Becher's approach to documentation, the mosques were all photographed with a straightforward, or so-called "objective," point of view.

The Bechers were a couple of German photographers and conceptual artists who started in the late 1950 s to systematically document industrial structures through photography. The idea was "to make families of objects" and "to create families of motifs" ${ }^{15}$ to highlight a common character that would be "implicit in a façade." ${ }^{96}$ Their approach was therefore a way "to offer the audience a point of view, or rather a grammar, to understand and compare the different

\footnotetext{
${ }^{94}$ Langford, 2007, p. 4

95 Bernd Becher in conversation with Jean-Francois Chevrier, James Lingwood, and Thomas Struth, quoted in Stimson, Blake, "The Photographic Comportment of Bernd and Hilla Becher", Tate Papers, no.1, Spring 2004. Accessed 1 March 2018, http://www.tate.org.uk/research/publications/tate-papers/01/photographiccomportment-of-bernd-and-hilla-becher

${ }^{96}$ Stimson, 2004, p. 3
} 
structures." ${ }^{97}$ I tried to emulate what art historian Blake Stimson calls the Bechers' "rhythmic continuity" ${ }^{98}$ because this photographic method allows for the emergence of a typology of sorts, as will be demonstrated in the third part of this thesis, with the unfolding of 5 selected themes: visibility, movement, opacity, threshold, and façade.

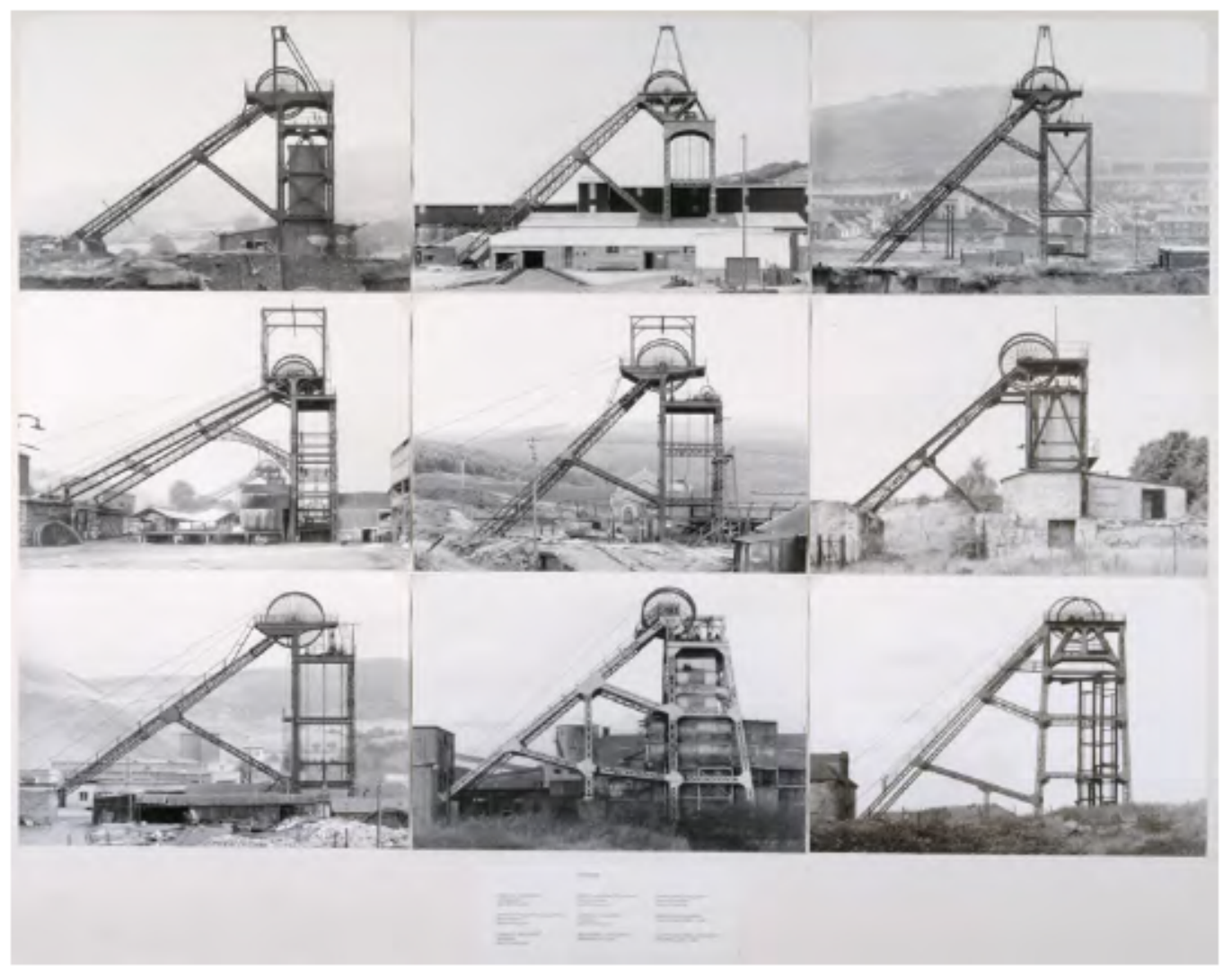

Figure 13 : 'Pitheads', Bernd and Hilla Becher, 1974

\footnotetext{
97 Liliane Touraine, ‘Bernd and Hilla Becher: The Function doesn't make the Form,' Artefactum, April/May 1989, p.9. Quoted in Stimson, 2004, p. 7

Stimson, 2004, p. 1
} 
To ensure continuity, every one of the 70 pictures was taken from the other side of the street, in broad daylight, and shows the level of busyness of the surrounding context. Architectural photography tends to reproduce a series of ideals - ideal lighting, ideal casting of shadows, ideal standpoint - but my photographs do not strive to reach these. My goal was rather, to quote the Bechers, "to produce a more or less perfect chain of different forms and shapes" ${ }^{99}$ in order to allow for certain types of connections to emerge. Together, these photographs form part of a visual atlas, organized following a series of itineraries that connect the buildings together.

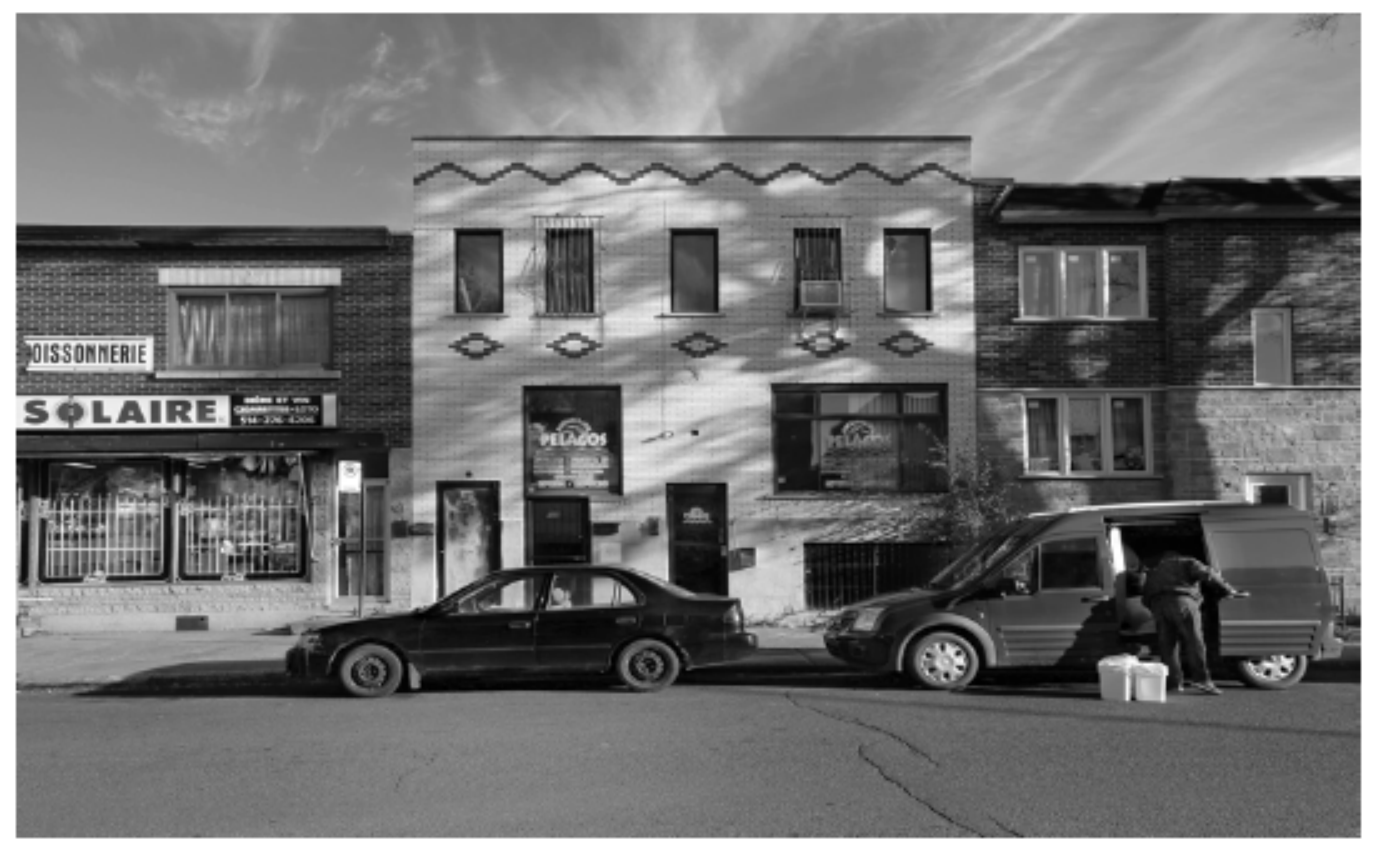

Figure 14: Madinah mosque in Parc-Extension

${ }^{99}$ Stimson, 2004, p. 12 

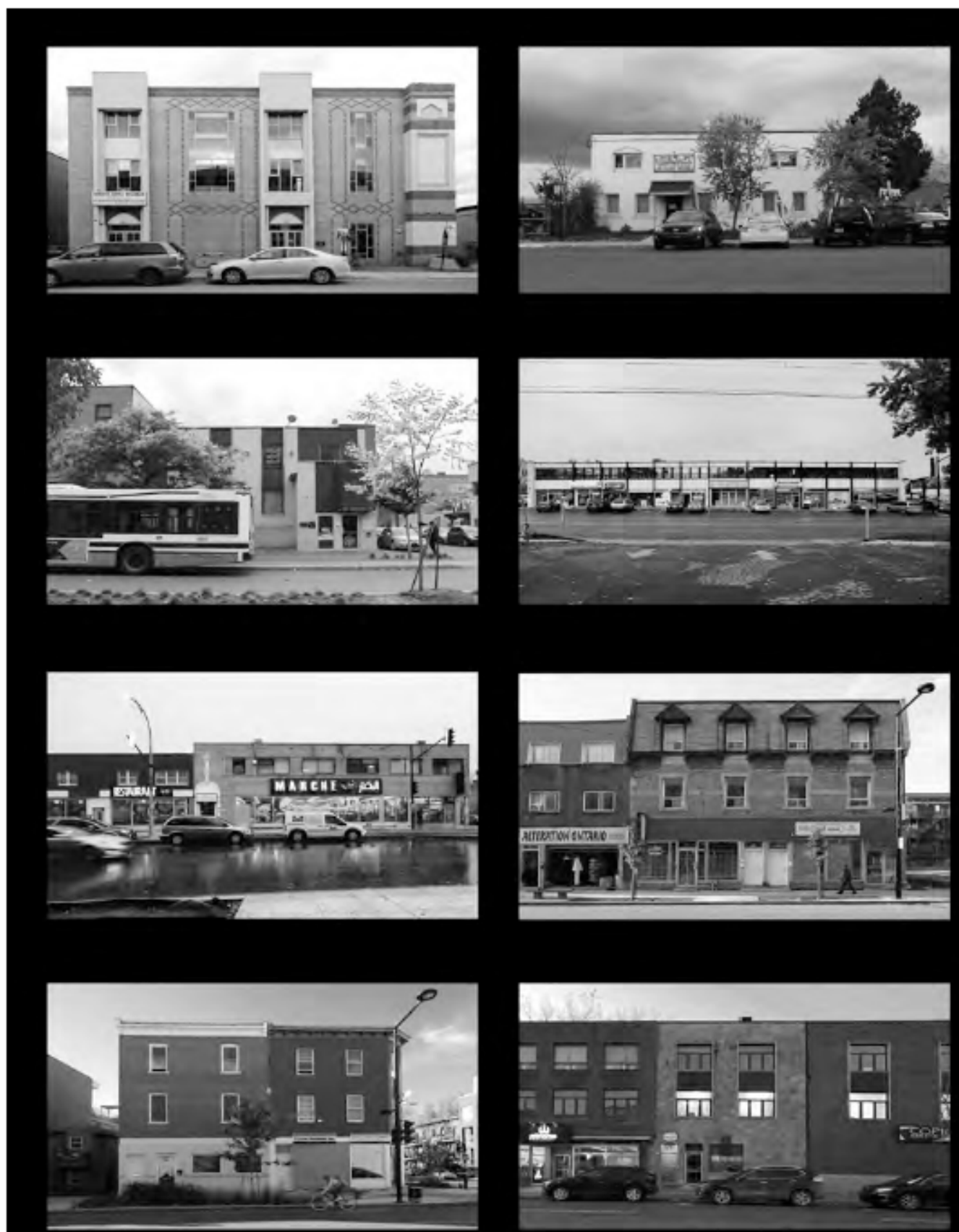

Figure 15: 8 mosques 
The reaction to these photographs surprised me every time they were a part of earlier design reviews. Each observer would read a different story in these apparently neutral pictures of simple buildings. This observation leads to the question of the roles played by both the photographer and the "spectator."

To be more precise, in this light, the audience - the watchers or readers - of these photographs take centre stage. "What do I expect from photographic experience and what part should I expect to play?", asks Langford. Or, to put it another way, what does my mind create when I "read" this photograph?

The notion of representation becomes important here. To represent is not to merely re-present, that is to evoke something that exists but that is simply not present here and now, where I stand. It is rather an image that we picture or that we are trying to convey. In other words, to represent is to create an image, in our own mind or in someone else's - to "make present" be it real or not. Representing something necessarily implies a part of imagining, of inventing. And in the act of inventing, one brings their own background and subjectivity.

${ }^{100}$ Spivak, 2009, p. 27 
If Susan Sontag famously wrote that "through photographs, the world becomes a series of unrelated freestanding particles" and that photography "is a view of the world which denies interconnectedness, continuity," ${ }^{101}$ I believe that placing the 70 photographs to form a series, in the fashion of the Bechers, can be seen as means for ensuring legibility, and for allowing the emergence of a possible interconnectivity. Taking these 70 photographs as a starting point, and taking into account my experience exploring the city, I identified 5 places of worship of particular interest. As we will see below, these 5 mosques ${ }^{102}$ correspond to 5 points of orientation in the city ${ }^{103}$ and to 5 selected characteristics, or typologies, that would later develop into 5 distinct narratives.

${ }_{102}^{101}$ Sontag, 1973, p. 17

102 They are, in order: the Centre Canadien Islamique Al Jamieh, the Al-Rawdah Mosque, the Ach-Choura Centre, the Al-Omah Al-Islamiah Mosque, and the Is Jamic Centre of Verdun.

103 It is common for most Montrealers to imagine the island as divided in 5 parts: North, South, East, West, and Centre. 


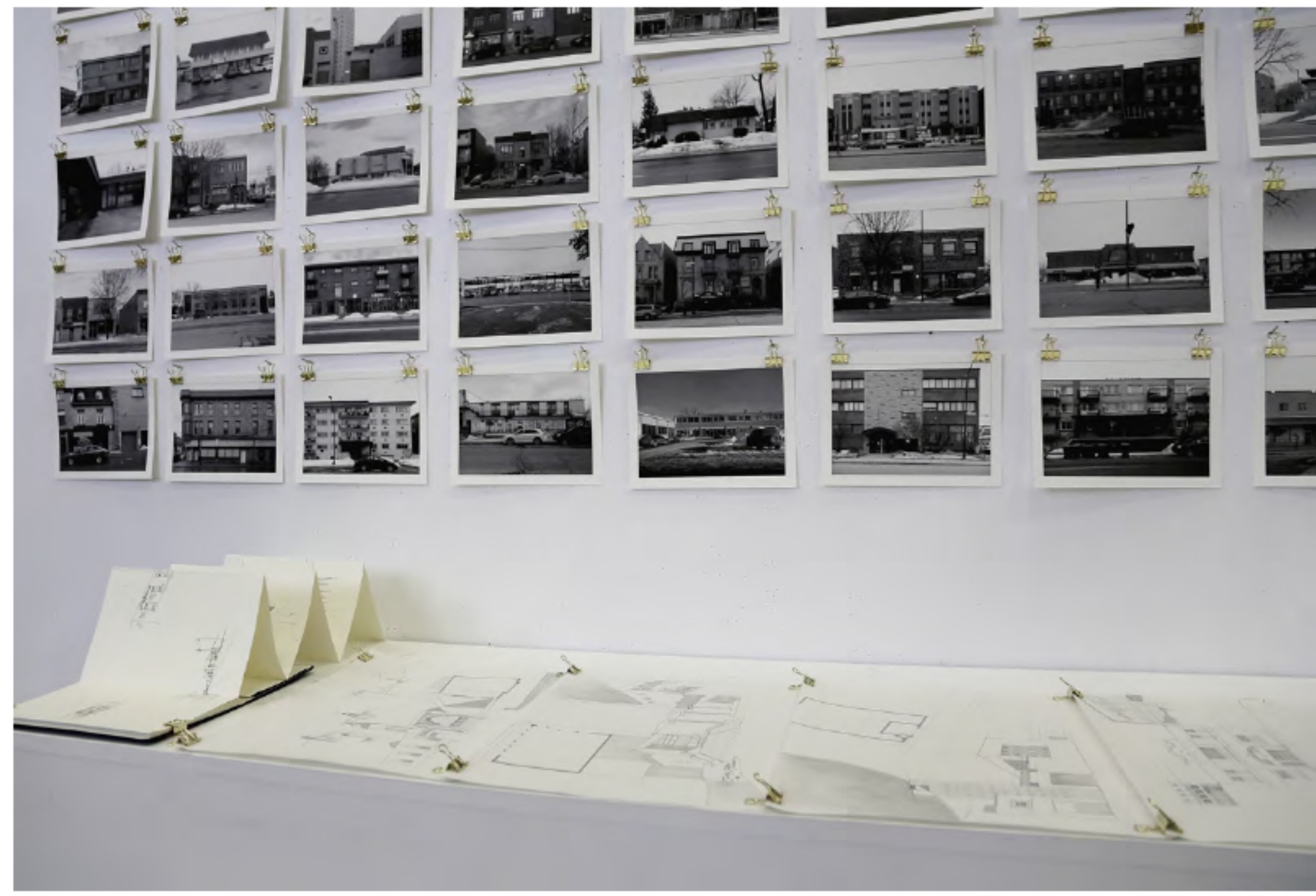

Figure 16: Atlas and experiential drawings 


\section{Positive / Negative}

Going further in the experimentation process on these images, the photographs were laser etched, creating a sort of paper-lace hybrid that, when placed in front of a luminous source, revealed the picture's negative. Echoing Carl Jung's idea of the shadow or double as "a replica of one's own unknown face,"104 these negatives hint that there might be something beyond what is simply visible from the street. The idea of the photograph's negative, or inversion, thus refers to the presence of a city within the city - a manifestation of its double and twin, revealing, in the process of working with the image, an illuminated building.

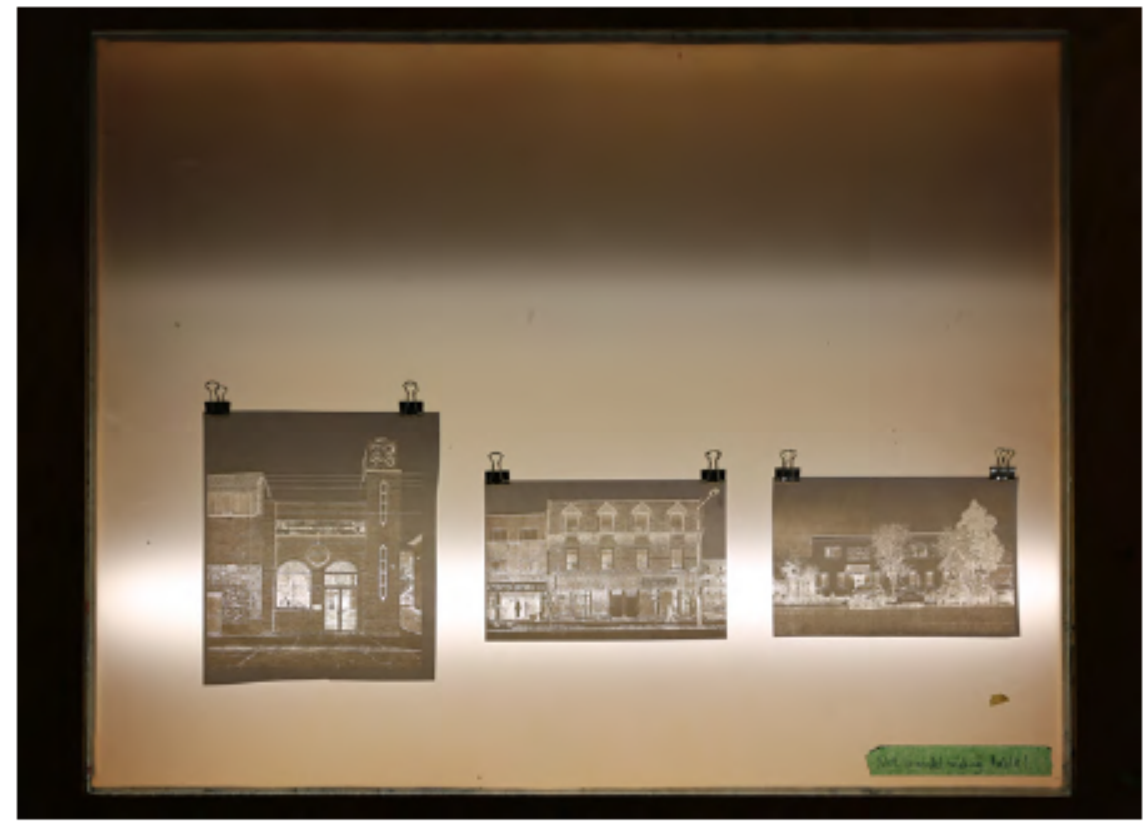

Figure 17: Etched photographs on a light table

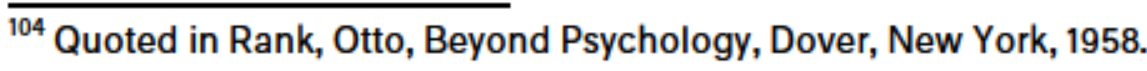




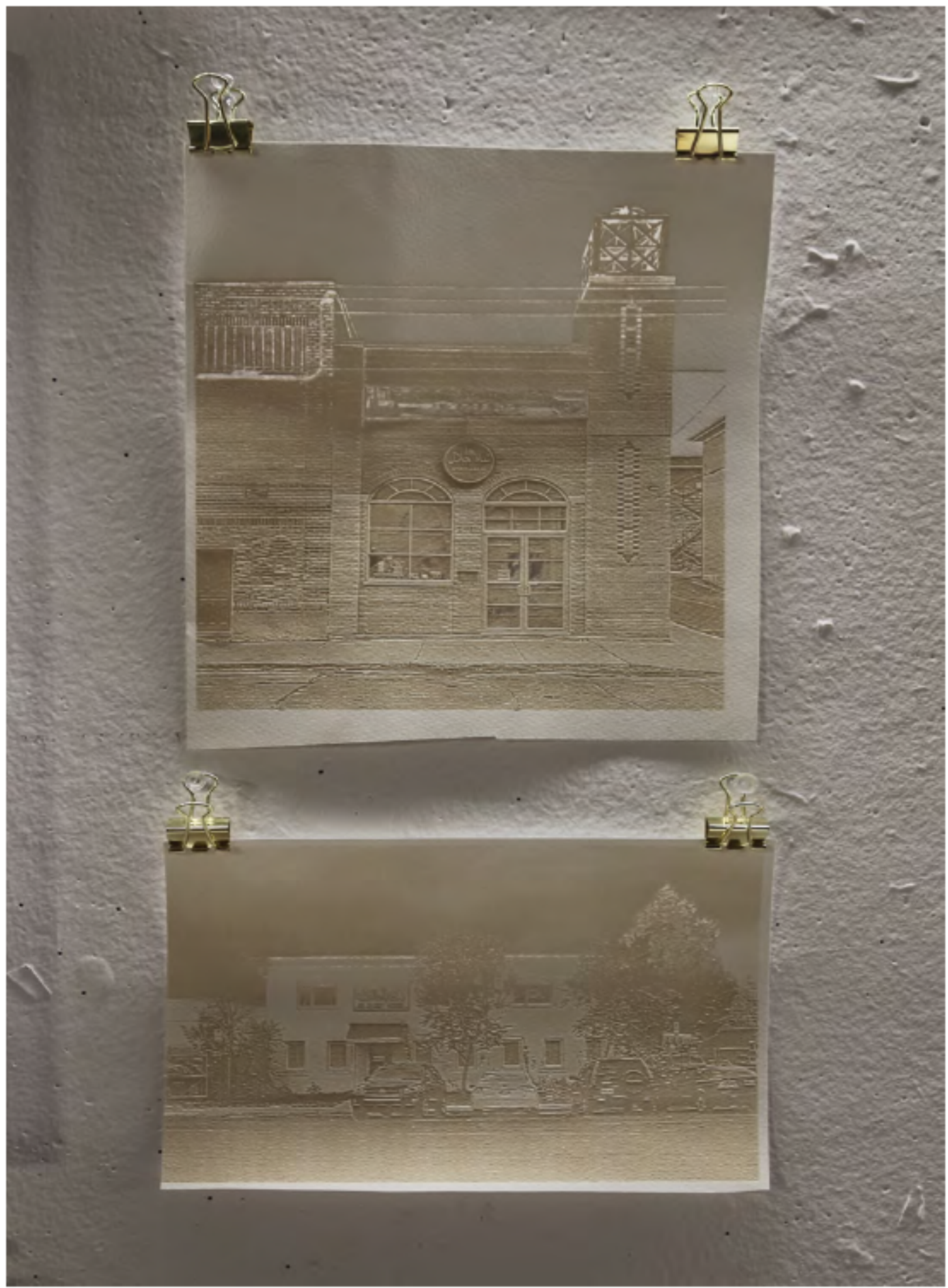

Figure 18: 2 etched photographs 
The negative is a simple reversing of the image. It becomes even more manifest in colour photography, as the negative image contains the complementary colours to that which is being photographed. The negative thus evokes the complementarity of the two parts of an image, as demonstrated in Henri Matisse's Formes (Fig. 14). Even though they can be perceived as opposites, the most striking aspect of the superimposition of the positive and negative is that they complete each other, like pieces of a puzzle.

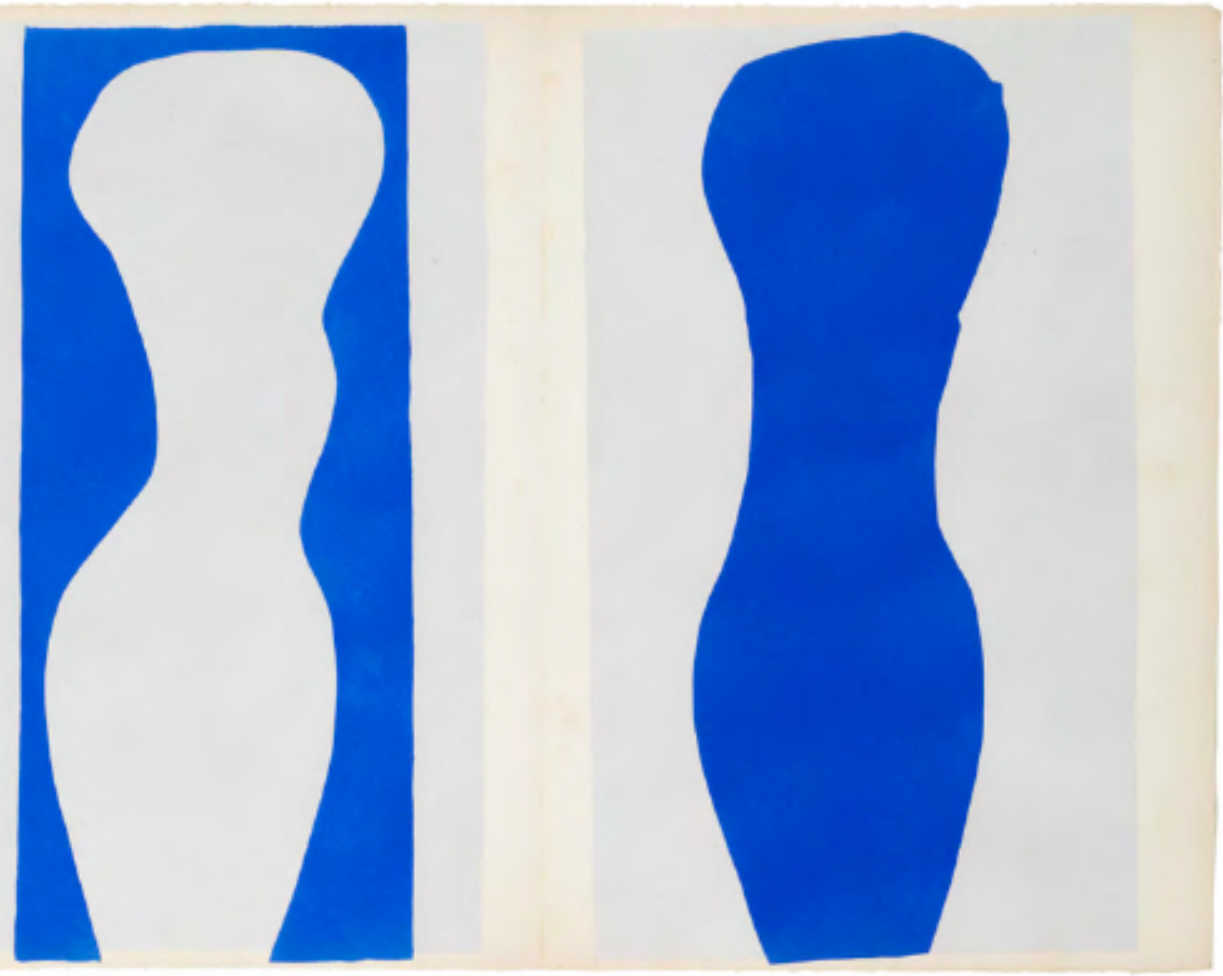

Figu re 19: Henri Matisse, Formes, 1947 
Historically, the negative has been used as a visual device to show dreamy settings or alternate universes. Because they are reminiscent of X-rays, they are also commonly used to represent things that are hidden or concealed. In this project, the use of negatives instead of positives also had the unexpected effect of bringing attention to areas of the building that were darker on the original pictures, just as the superposition of the 2 pictures in Fig. 15 evokes a void eventually filled by air. In the same way, the openings - doors, windows, and store front windows - in Fig. 16 are highlighted, reinforcing the intention to bring the sacred spaces forward, to illuminate them.

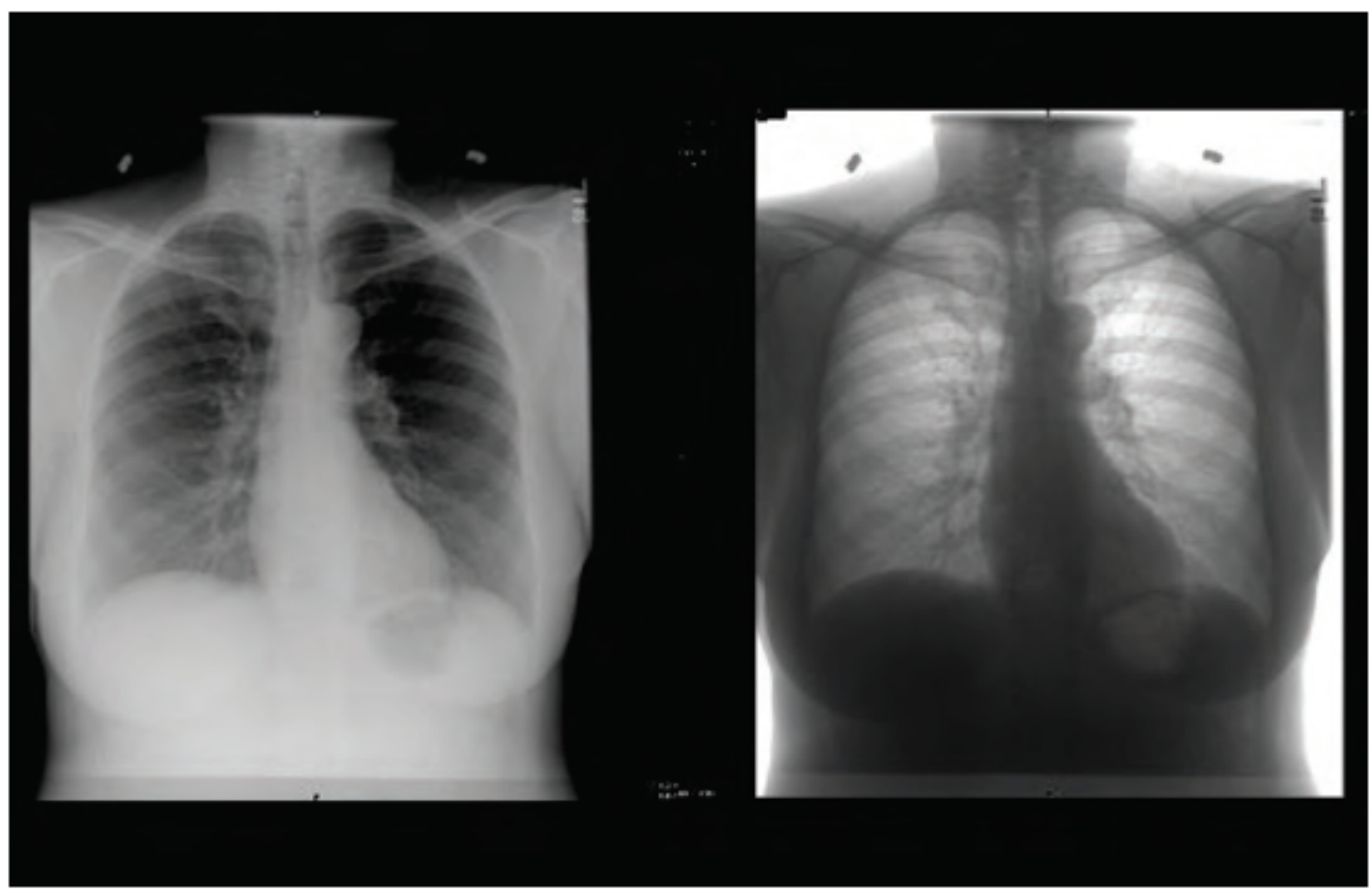

Figure 20:X-ray of a thoracic cavity 


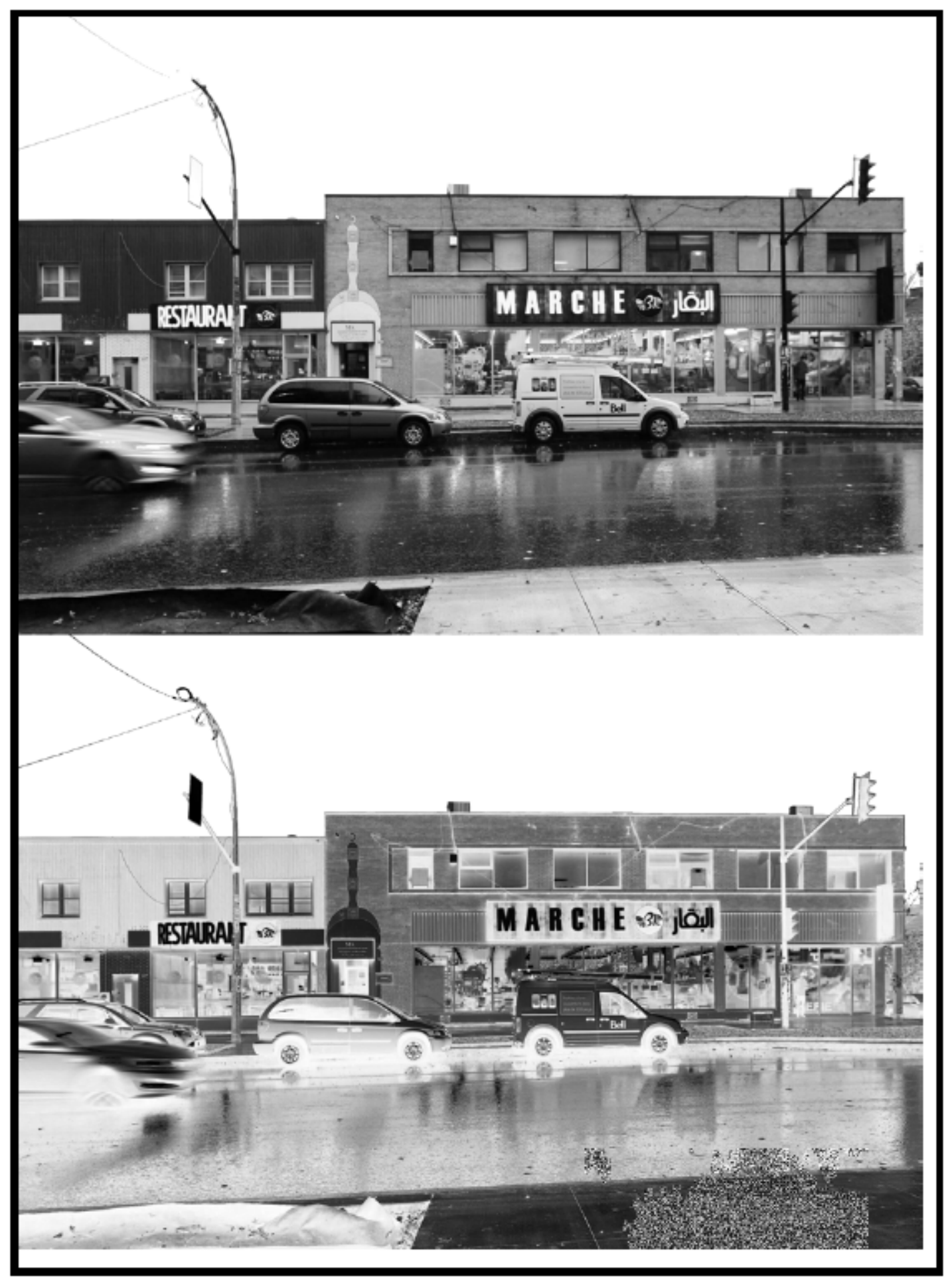

Figure 21: Al-Rawdah mosque, positive and negative 
This strategy of illuminating the negative has been used to highlight the mosques that were chosen to explore the 5 narratives (visibility, movement, opacity, threshold, and façade). I then drew "speculative" sections of the buildings based solely on the information I could gather from walking around them and from looking through their openings. These drawings necessarily show a lot of blank spaces, as I did not go inside. They therefore constitute a sort of blacked out / whited out document, inviting the observers to fill the blank themselves. The experience of reading the photographs and letting the possible narratives emerge constituted an important part of my approach to these buildings. These illuminated drawings are an invitation to the audience to take part in the process, as the other readers are welcome to complete mine with their own interpretation.
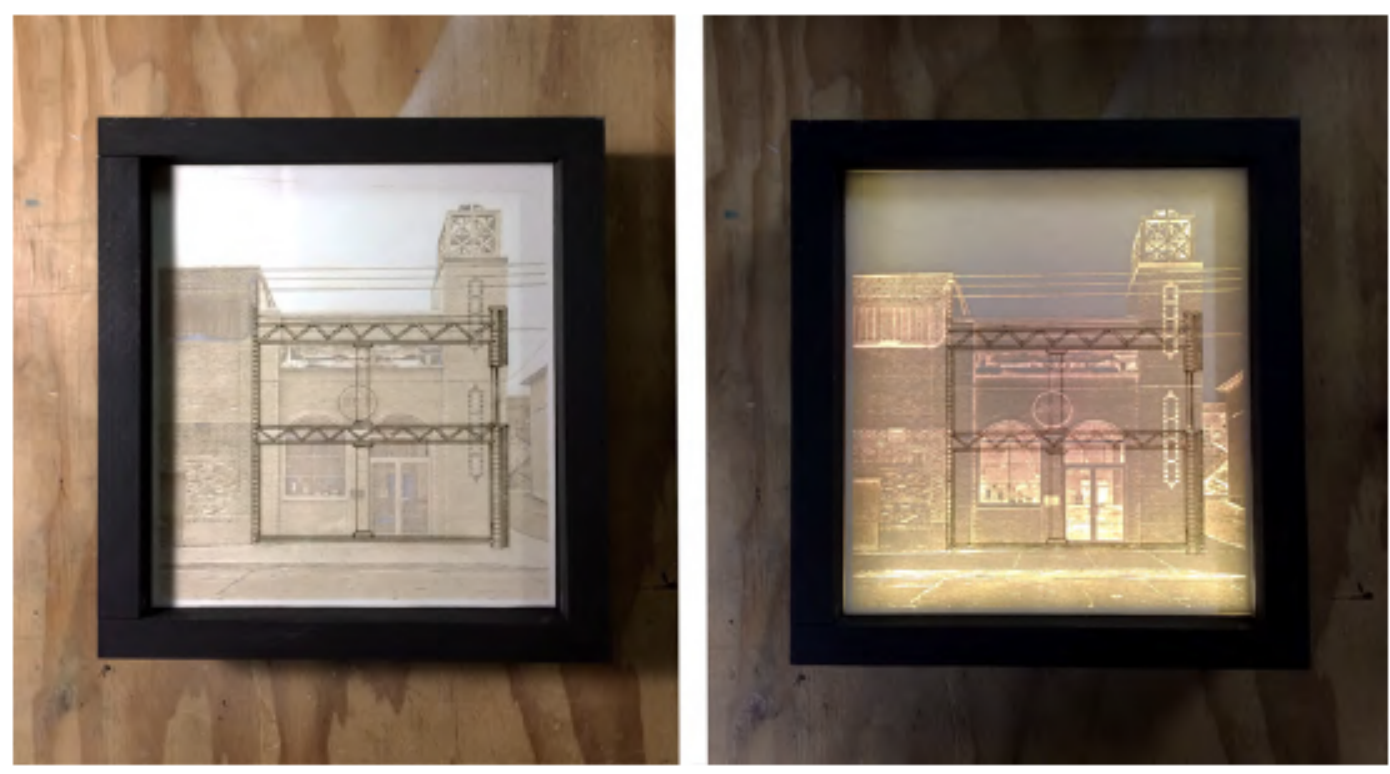

Figure 22: Backlit frame with speculative section 


\section{Illumination}

Illumination, the act of ornamenting with gold, is part of a rich book art tradition in both Christianity and Islam. Etymologically, to illuminate something is to light it up, to embellish it in order to bring attention to it. The art of illumination requires patience and great care, as gold leaves are meticulously applied on a surface to make it appear as though it is infused with light and emits light as well. Illuminated spaces both receive and project.

Once all the photographs had been collected and the mosques had been compiled, I modeled the series of 5 mosques previously chosen according to the narratives I wanted to explore. The prototype for this series was a 1:200 reproduction of the Shah Jalal Islamic Centre, located in Saint-Henri, in the Southwestern part of the island.

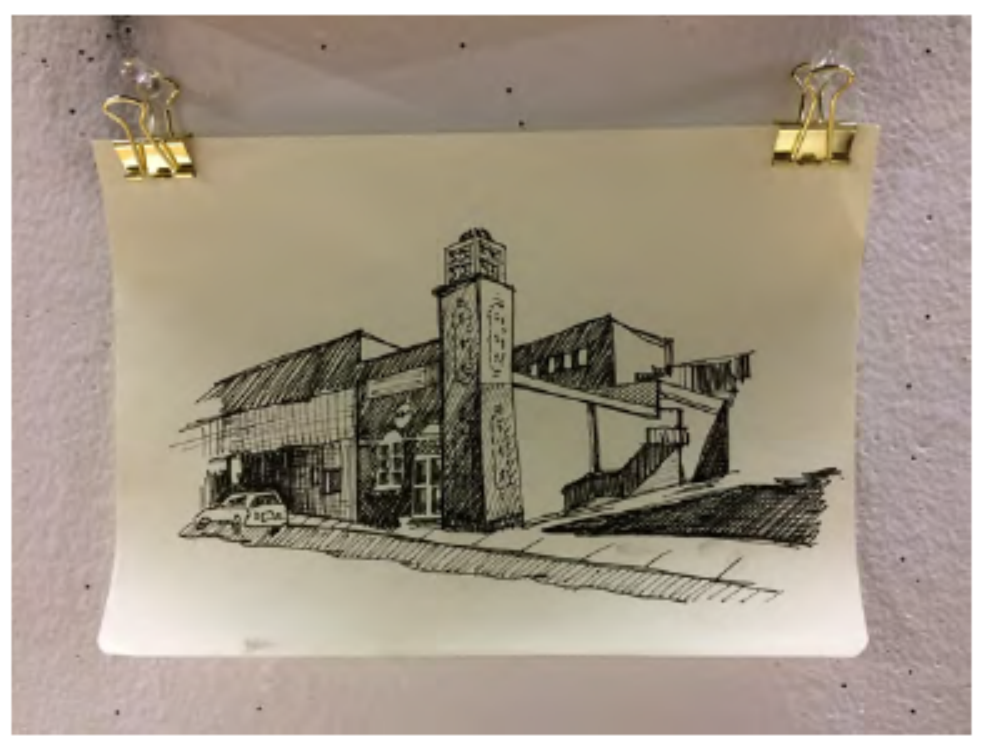

Figure 23: Sketch of Shah Jalal mosque 


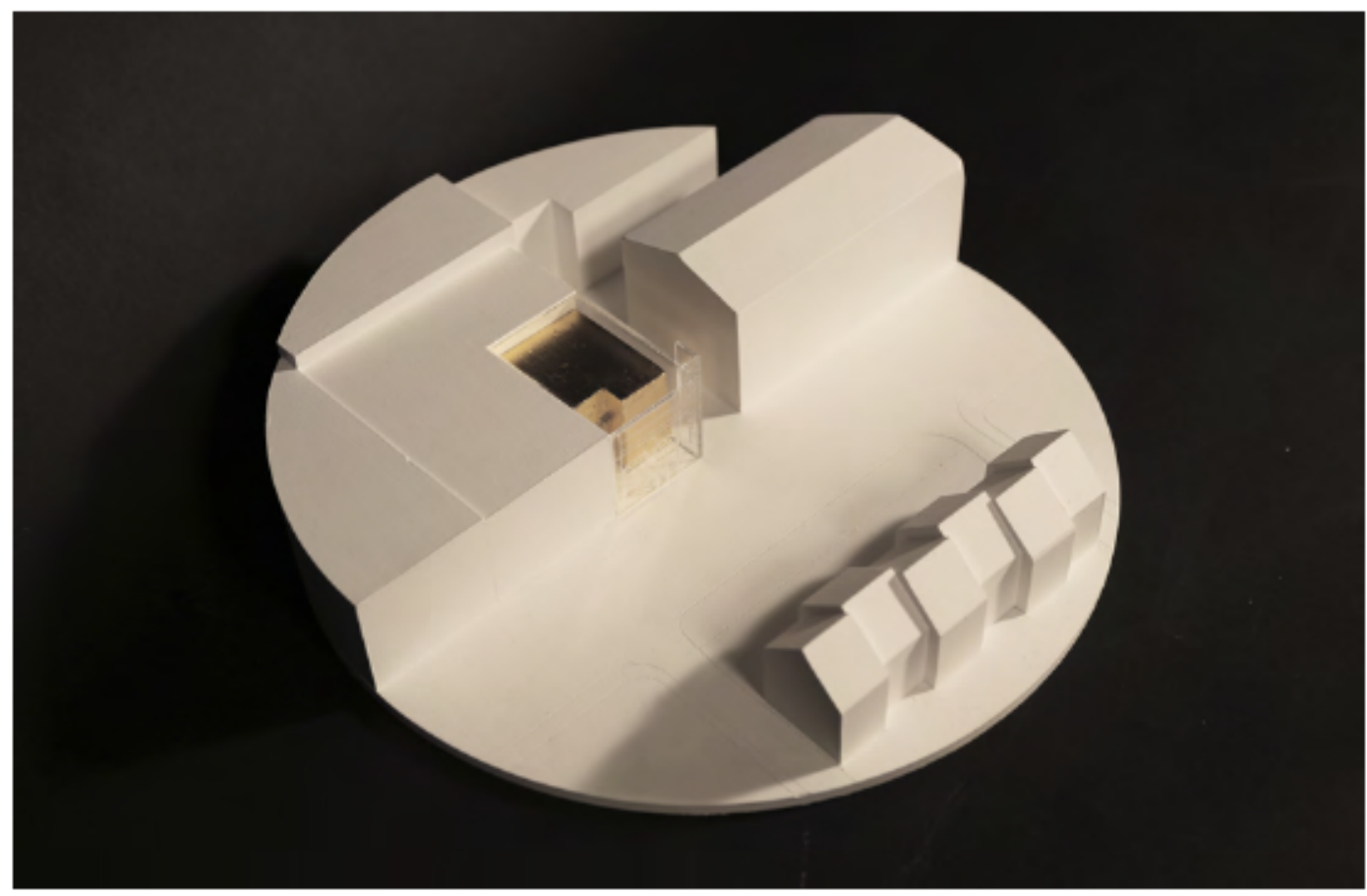

Figure 24: 1:200 model of Shah Jalal Islamic Centre 


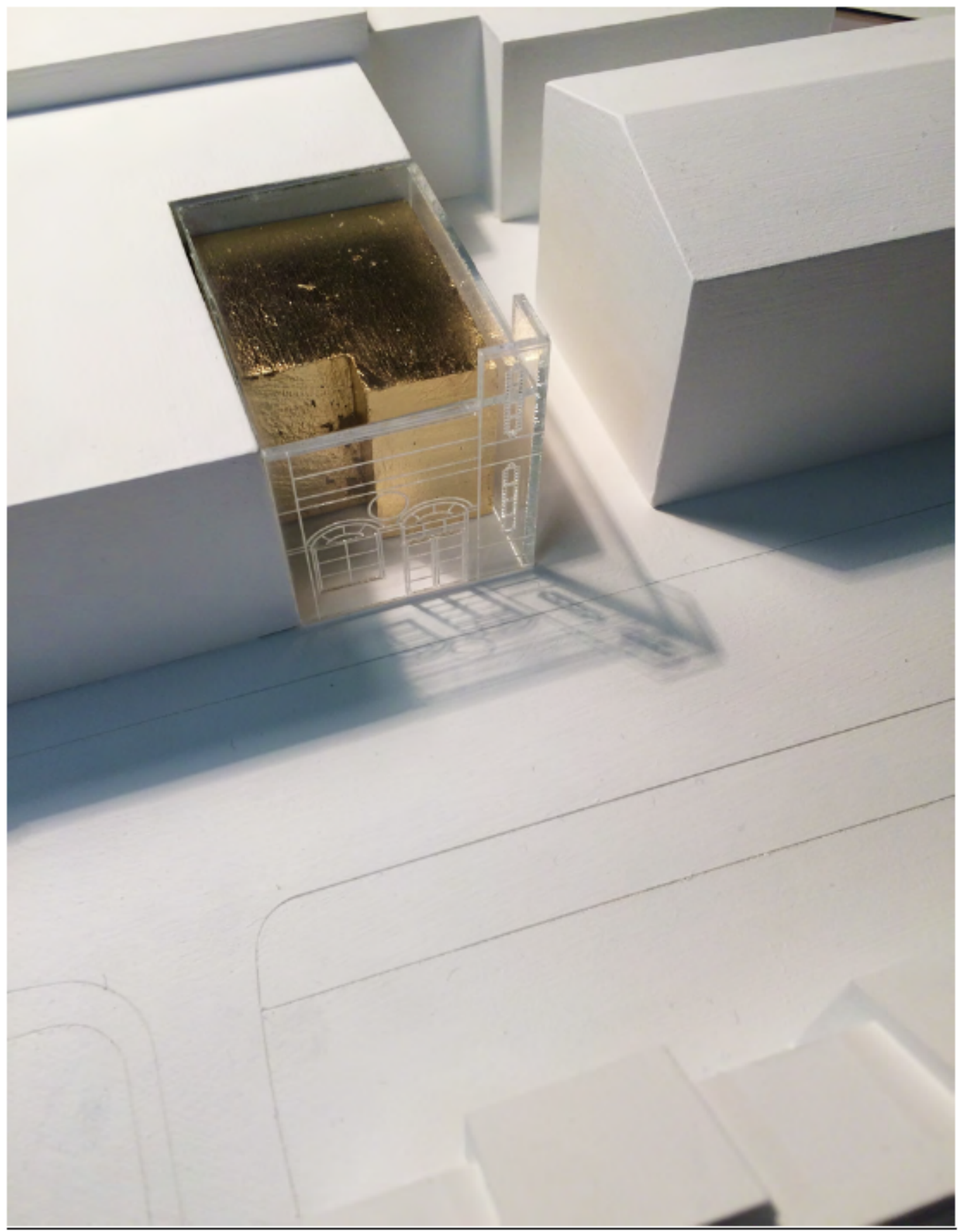

Figure 25: 1:200 model of Shah Jalal Islamic Centre 


\section{Interpretation}

My reading of the buildings is based on my training, both as a professional carpenter and as an architecture student. I looked at the mosques from outside, walking around them when it was possible. The only reference I used for representing the buildings are what I perceived and recorded, and the dimensions were interpreted based on the number of bricks and the data from Montreal's public cadastral plan. I translated my recordings by using the same method of focusing on the blank spaces mentioned above when talking about the speculative sections, and so I chose to use 3 different materials to represent 3 characteristics of the documented spaces.

First, The white buildings and streets represent the "secular" or socalled "neutral" space - the white space, as Sara Ahmed would call it. Second, the building itself is made of clear acrylic, to indicate what is legible from a passerby's point of view - an expression and translation in model form of the earlier photographic studies. Finally, the volume inside the building, adorned with gold, represents what is not accessible to the outsider's gaze and is often the space where the rituals of the faith take place and ultimately, make space. The attempt here was to highlight and express the notion of an "other" city layered within a city, a city through which another world resides, is inhabited. 


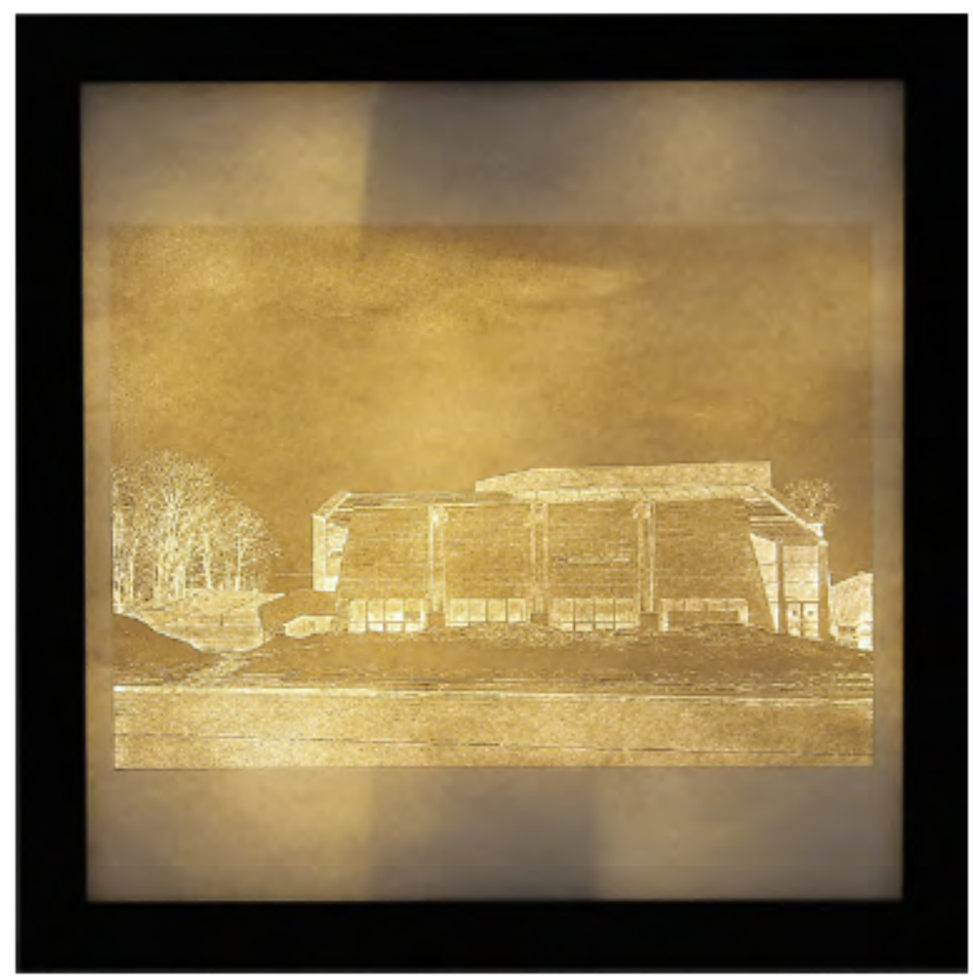

Figure 26: Etched picture of Al-Jamieh Islamic Centre

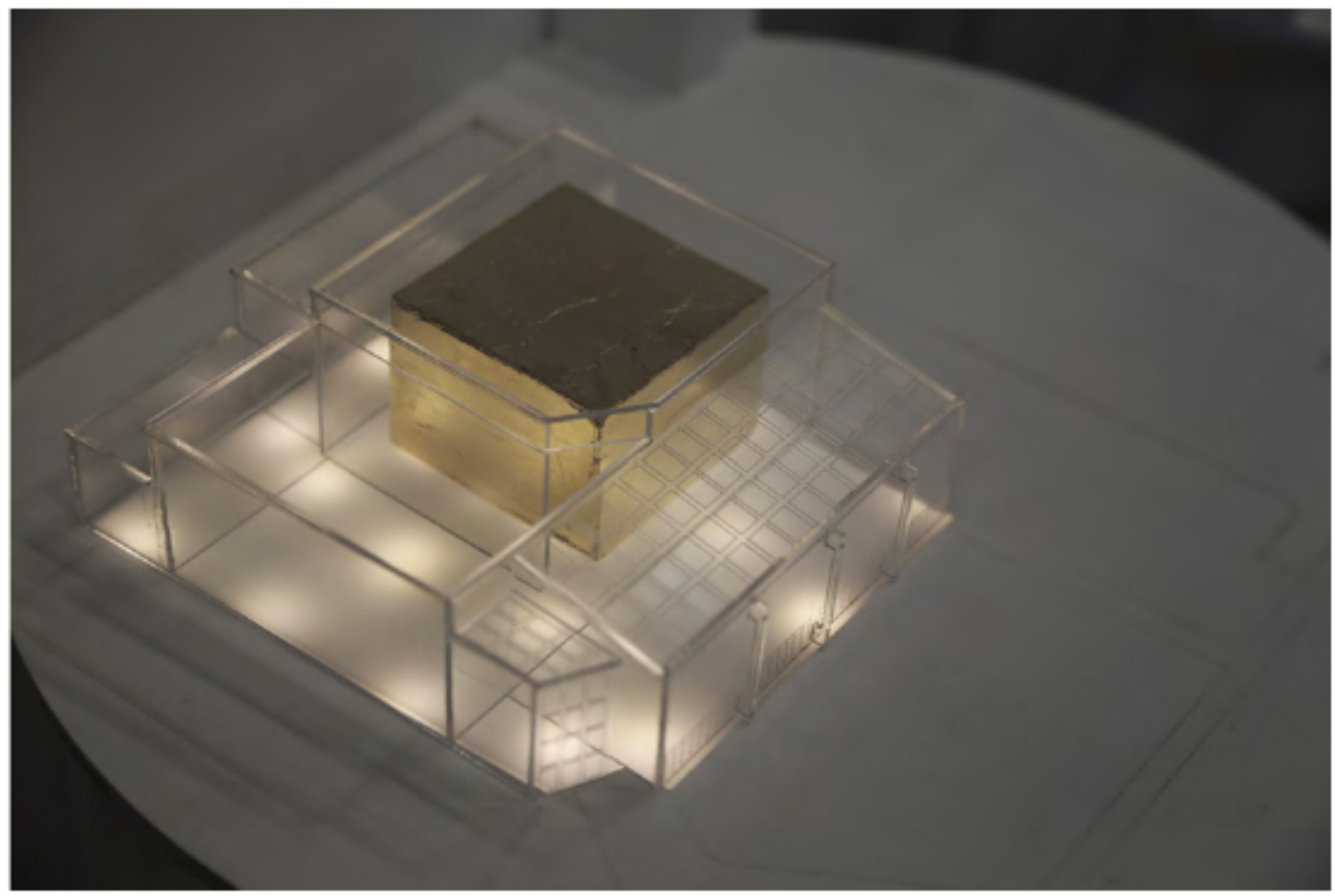

Figure 27: Model of Al-Jamieh Islamic Centre 


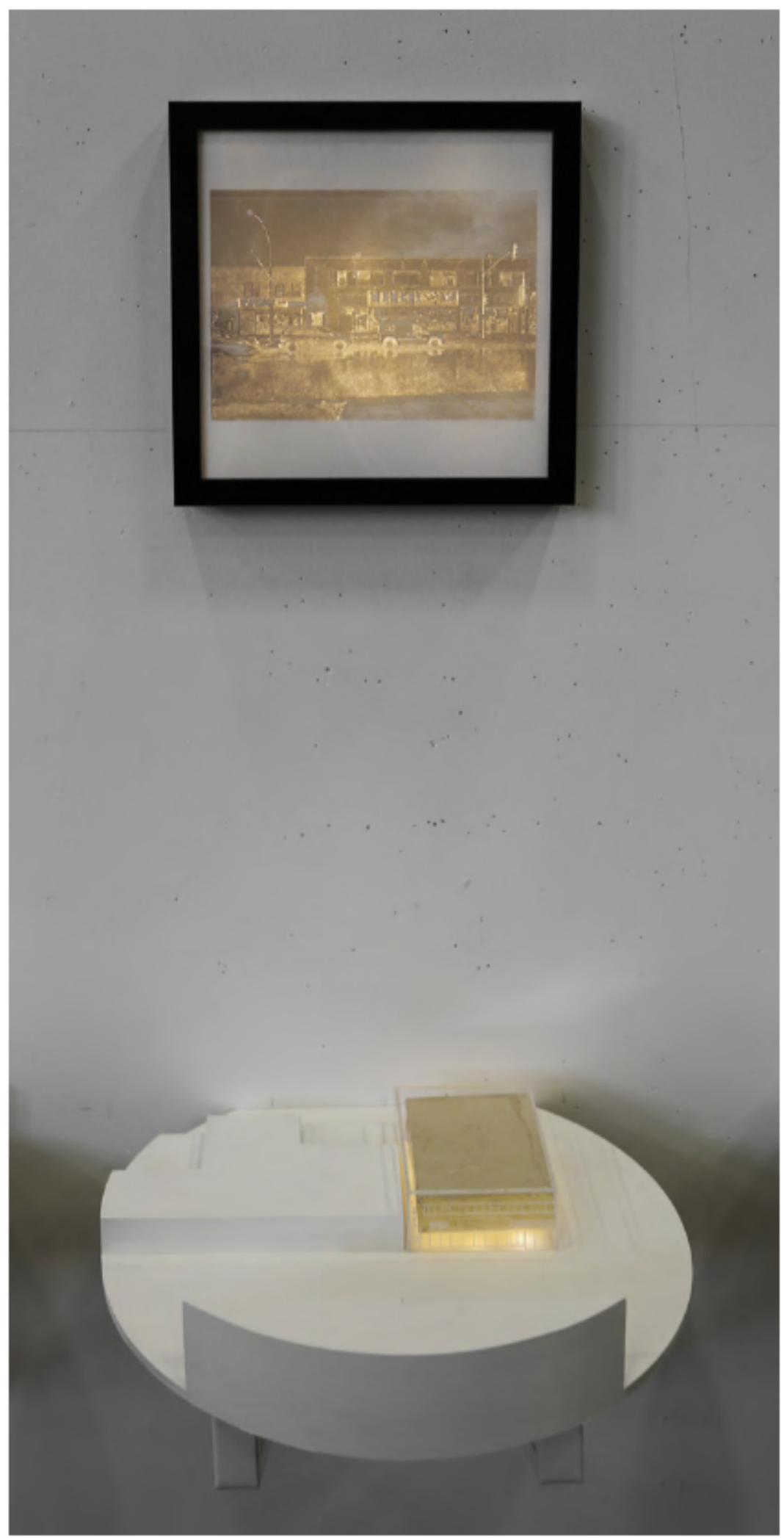

Figure 28: Photo \& model of Al-Rawdah mosque 


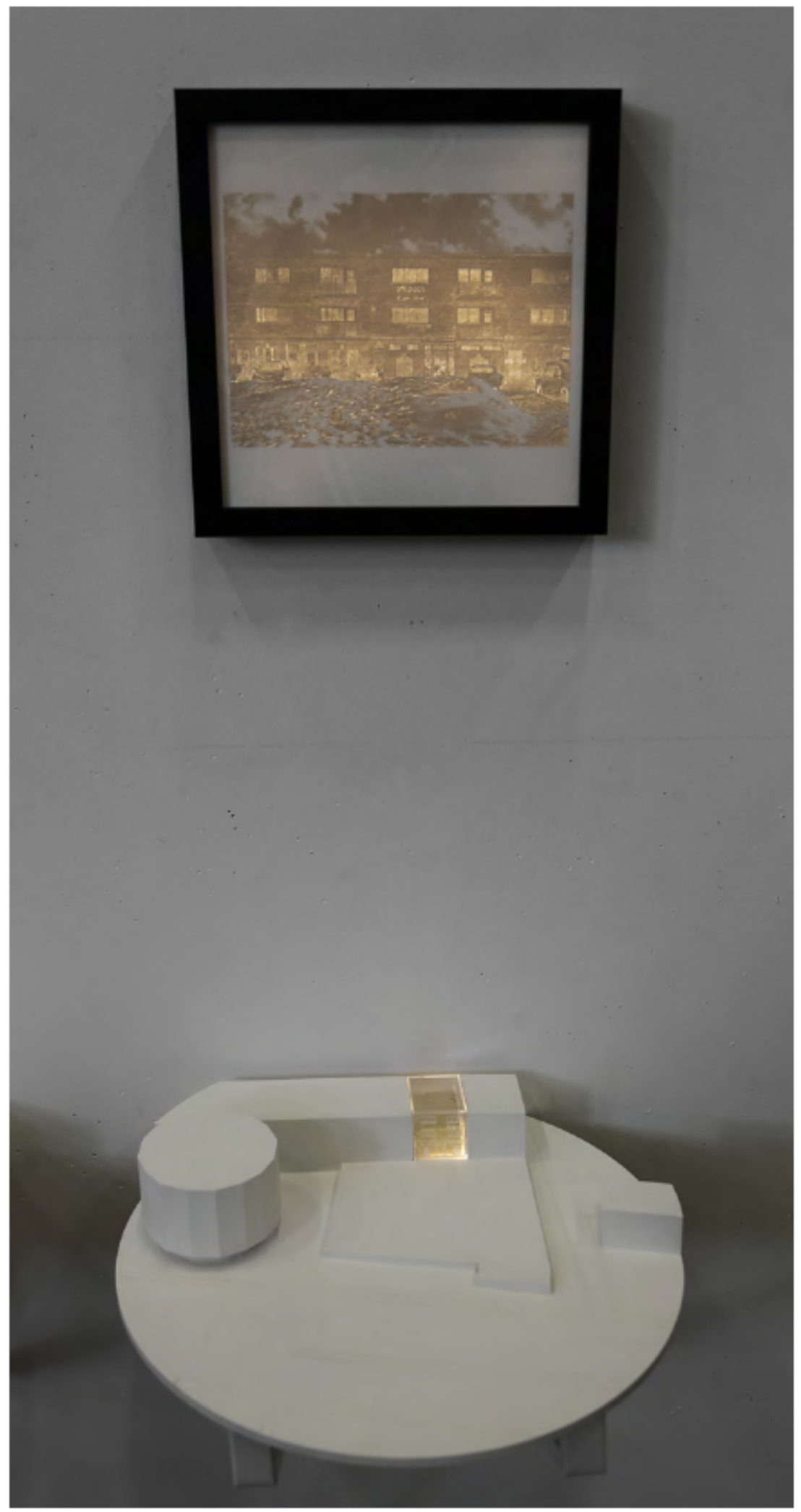

Figure 29: Photo \& model of Ach-Choura Centre 


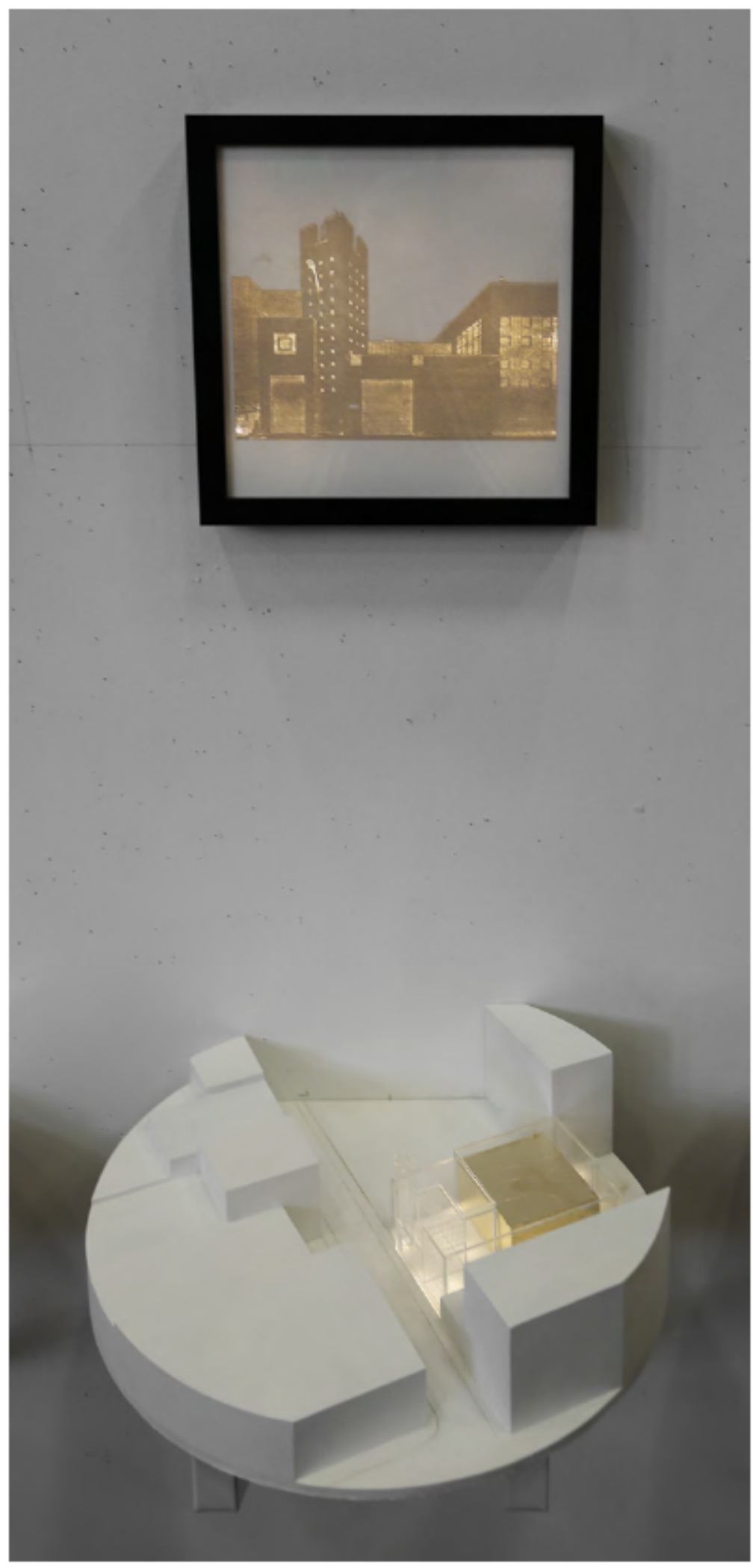

Figure 30: Photo \& model of Al-Omah Al-Islamiah mosque 


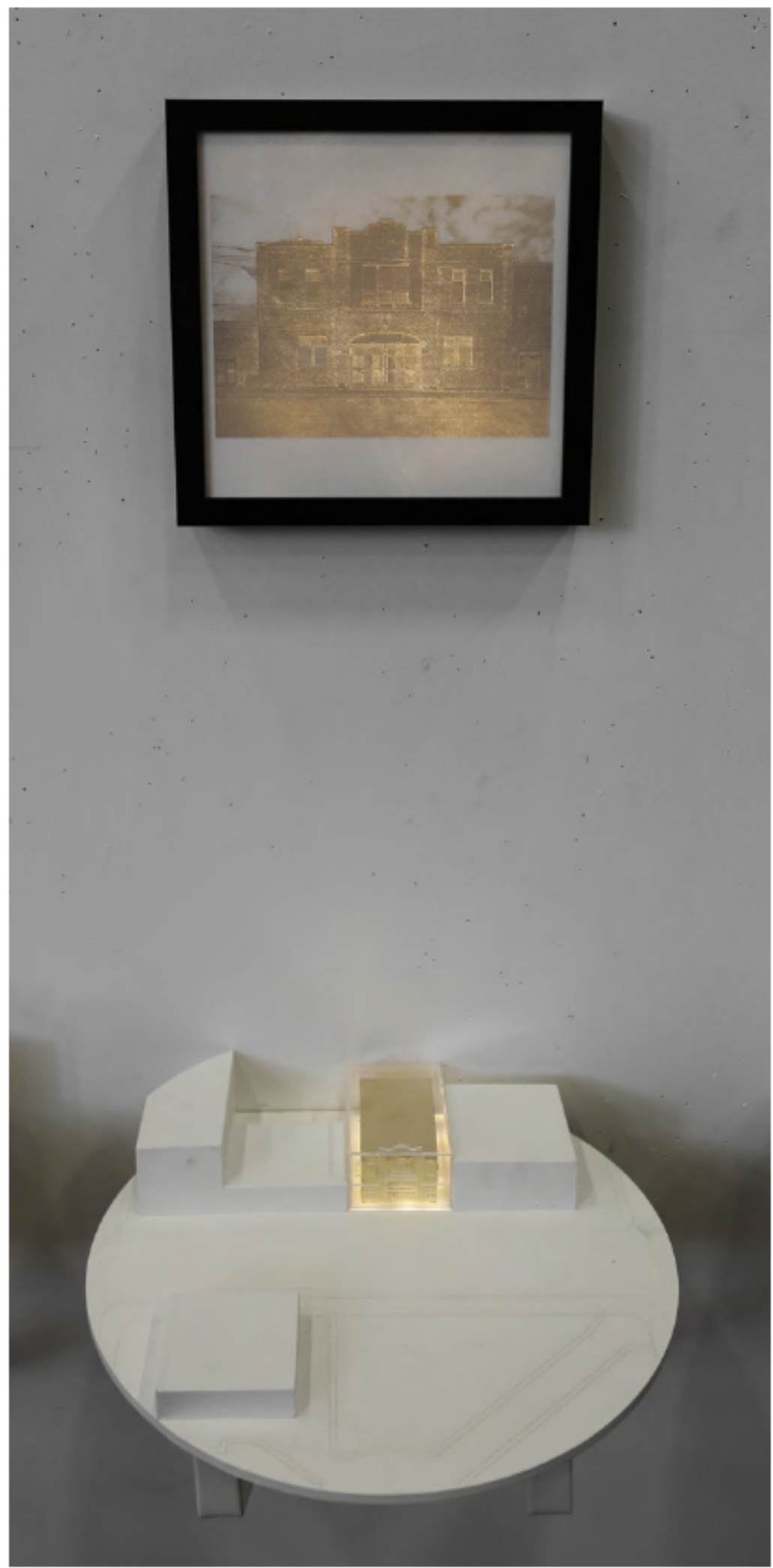

Figure 31: Photo \& model of Islamic Centre of Verdun 

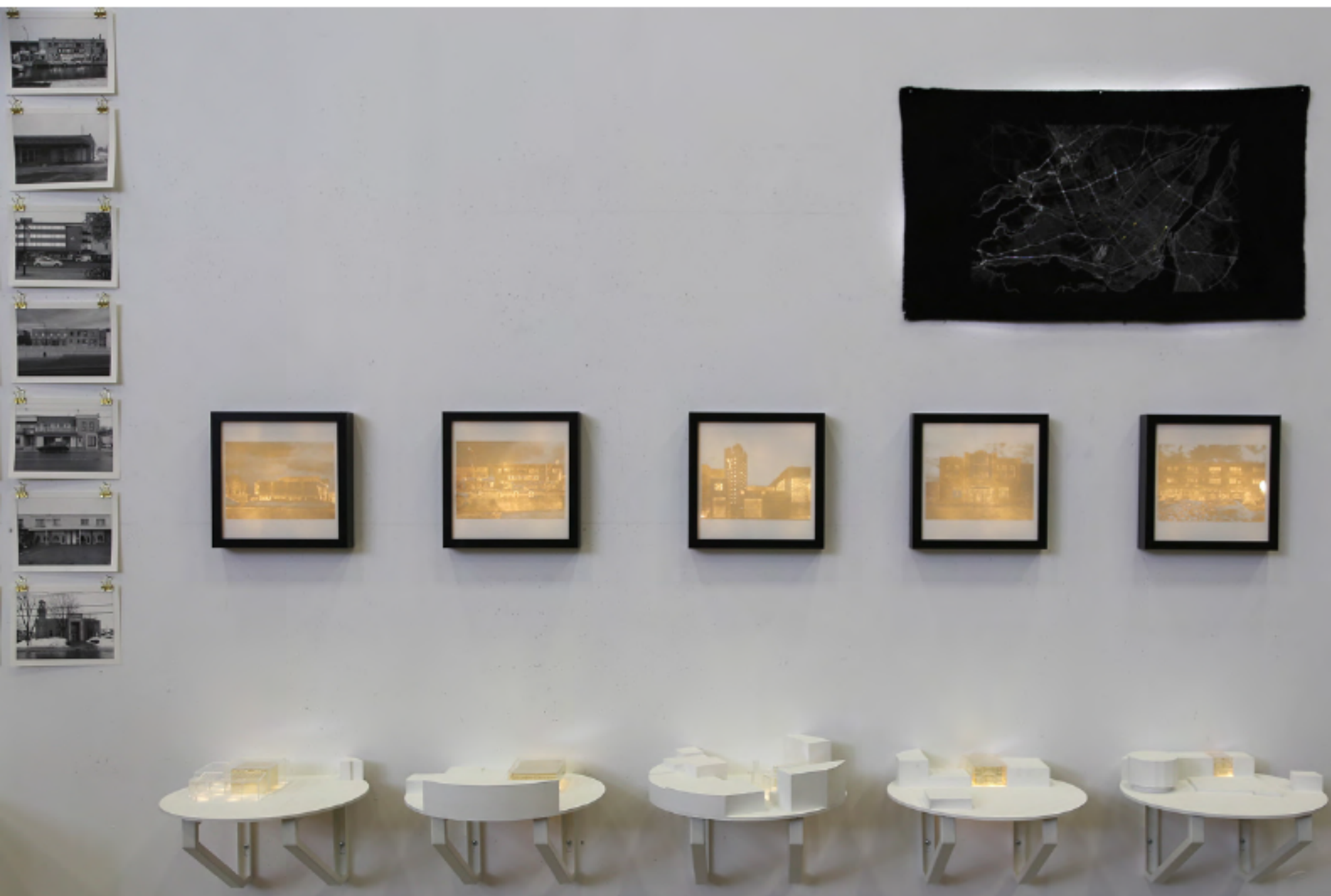

Figure 32: Models and etched photographs 


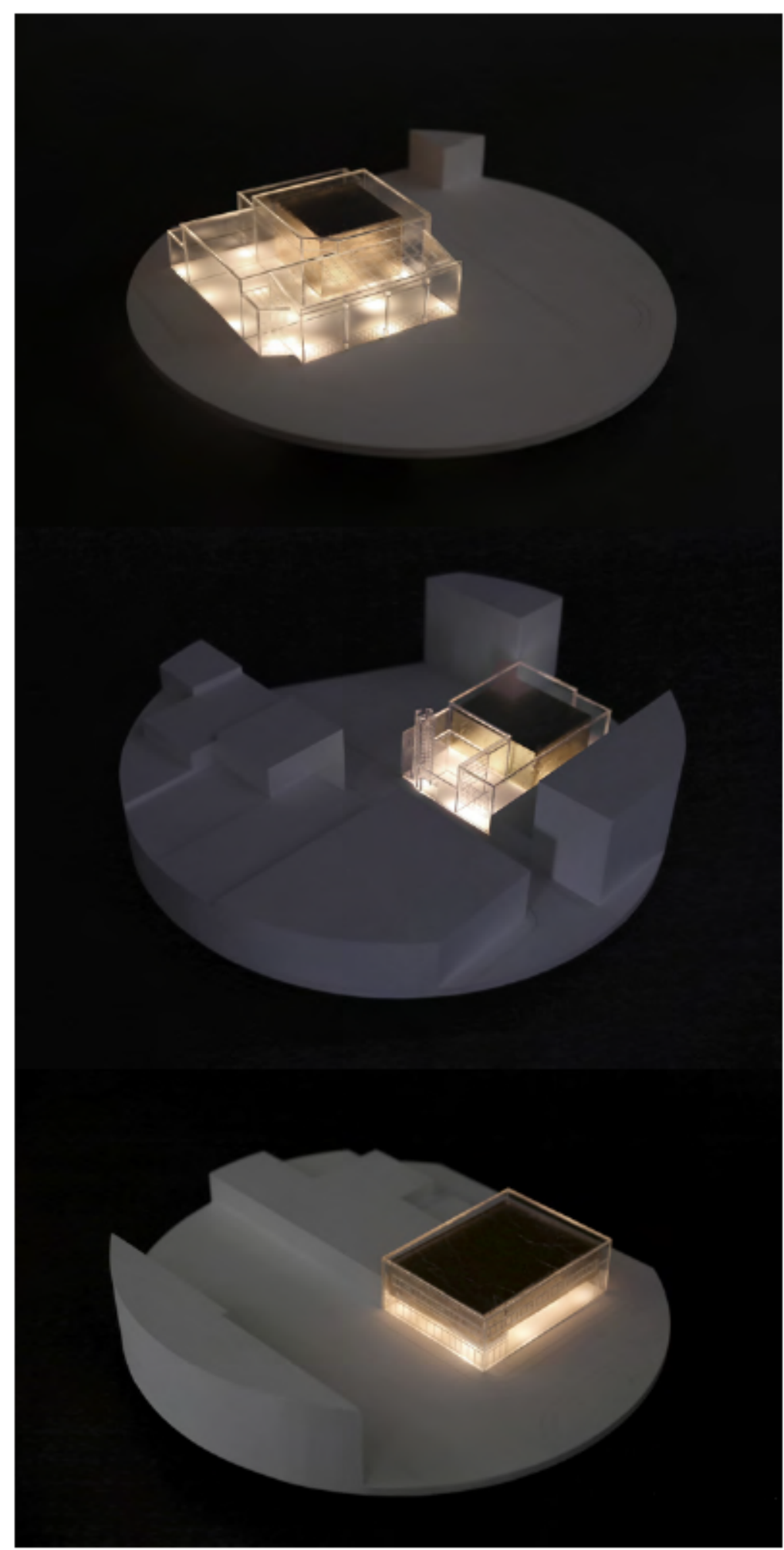

Figure 33: Illuminated models 


\section{Fabric}

"Urban fabric" is one of the most common and taken-for-granted idioms in architecture and urban planning. For this research, I found it relevant to investigate further the allegory of the city as a fabric, since fabric is constituted of threads that are woven together and that give the impression of a uniform piece of material, a coherent one-ness.

Transposed to the idea of urban space, the widely-used allegory of "urban fabric" refers here to this same idea: that the physical aspect of the space we call "city" is constituted of a (tight or loose) weave of buildings, façades, open spaces, streets and thoroughfares, and landscapes/streetscapes. That space has personalities, distinct essences, just as recognizable as the piece of material to which it refers.

I printed a map of Montreal on a piece of black wool, and started sewing golden beads to indicate the mosques I had already photographed and included in the atlas. Itineraries connecting these mosques were then sewn with gold thread, in an attempt to communicate the spatial trajectory of my body in space. This map is a work in progress, as I sewed, and will continue to sew, beads each time a new mosque was, or will be, added to the atlas. 


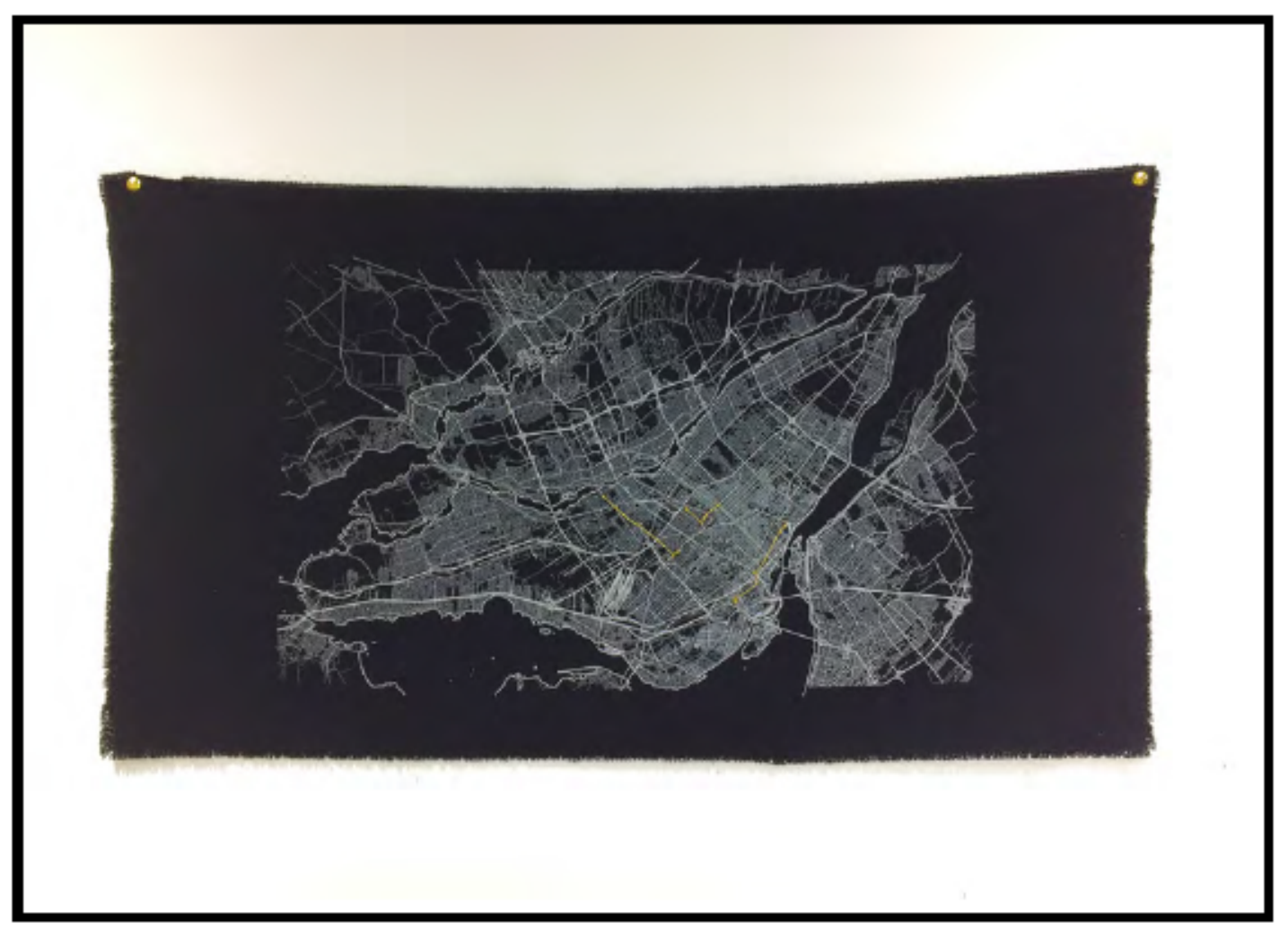

Figure 34 : Wool map of itineraries

The use of wool not only refers to the common expression tricoté serré, or "close-knit," but also to the widespread term pure laine, "pure wool." As Meena Sharify-Funk and Elysia Guzik explain in their essay Muslim Veiling and the Legacy of Laïcité, the concept of pure laine

... has been used at least since the latter half of the twentieth and into the twenty-first centuries to justify a stance that many religious minority groups experience as exclusive. Instead of acknowledging the diversity within Quebec [...], pure laine frames diverse religious influences within Quebec society - including Indigenous spirituality, atheism, Catholicism, Islam, and various other traditions as inauthentic. From this perspective, the presence of religious difference is denied credibility as a basis for 
identity formation and regarded as a threat to the maintenance of a cohesive social fabric. The prevalent concern about religious minorities changing the majority Québécois culture hampers engagement with cultural difference and establishes boundaries to openness of thought. ${ }^{105}$

Using wool as a base for the map and then sewing golden embellishments on it illustrates how, even if the weave is very tight, there is always a place for a thread to be sewn. In some cases, thread can be used to repair or patch a piece of torn or broken fabric.

${ }^{105} 2017$, p. 186 


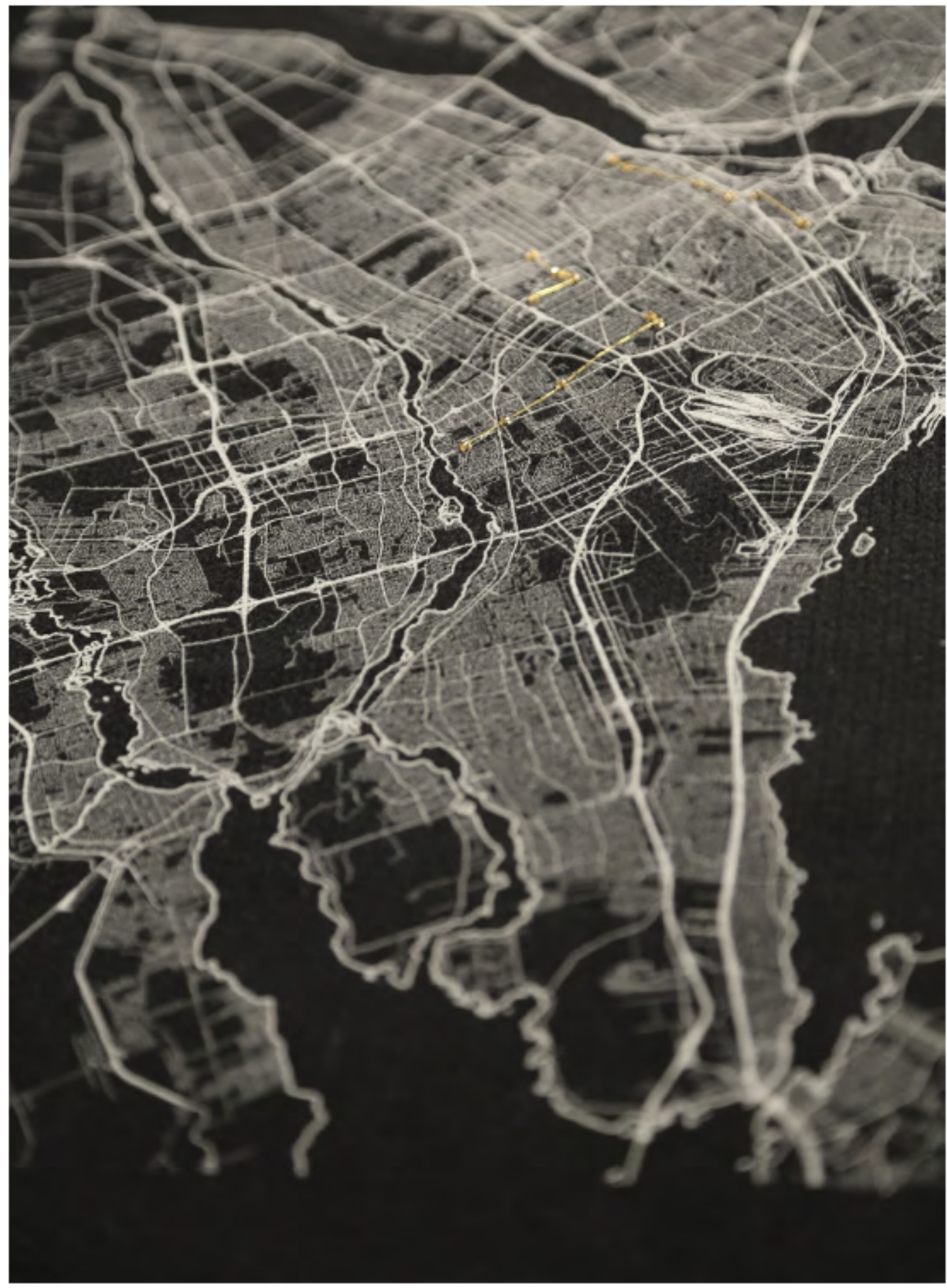

Figure $35: 3$ itineraries on the wool map 


\section{Part III : Narratives}


The narratives were chosen as a point of departure to think about a way to visually represent, through drawings, some aspects of a spatial experience of these buildings. They were developed around 5 mosques, that are themselves linked to 5 themes, 5 spatial points in Montreal, and 5 poems that explore Islamic culture.

\section{Drawing process}

As a photographer, I witnessed the presence of 70 buildings in the urban fabric and I "neutrally" registered their presence in the form of photographs. As a reader of these photographs, I associated 5 of the 70 buildings with 5 recurring themes, and then drew my interpretation of these stories.

In this last phase of the visual exploration, these themes were used as means to inspire the drawings of the multiple possible way of experiencing these buildings. This was achieved by drawing what Andrea Ponsi calls "perceptive maps," in which "the experience of space is interpreted using graphic operations in which reasoning, sensation, and emotion are melded together with the participation of all the body's senses.. ${ }^{106}$ In Ponsi's words,

\footnotetext{
${ }^{106}$ Ponsi, Andrea. "Perceptive Maps." StudioPonsi.it.
} 
... subjective maps allow to represent changing views, spatial sequences, perceptive contrasts like high and low, near and far, light and dark. They can suggest sensations associated with textures, materials, colours. They can see through the walls of buildings, penetrate the space between edifices, draw from above, as in a bird's-eye view, landscapes, built environments, cities. ${ }^{107}$

This exercise allows for a critical exploration of the perception of space and time, as multiple testimonies are being superposed together to construct a new reality.

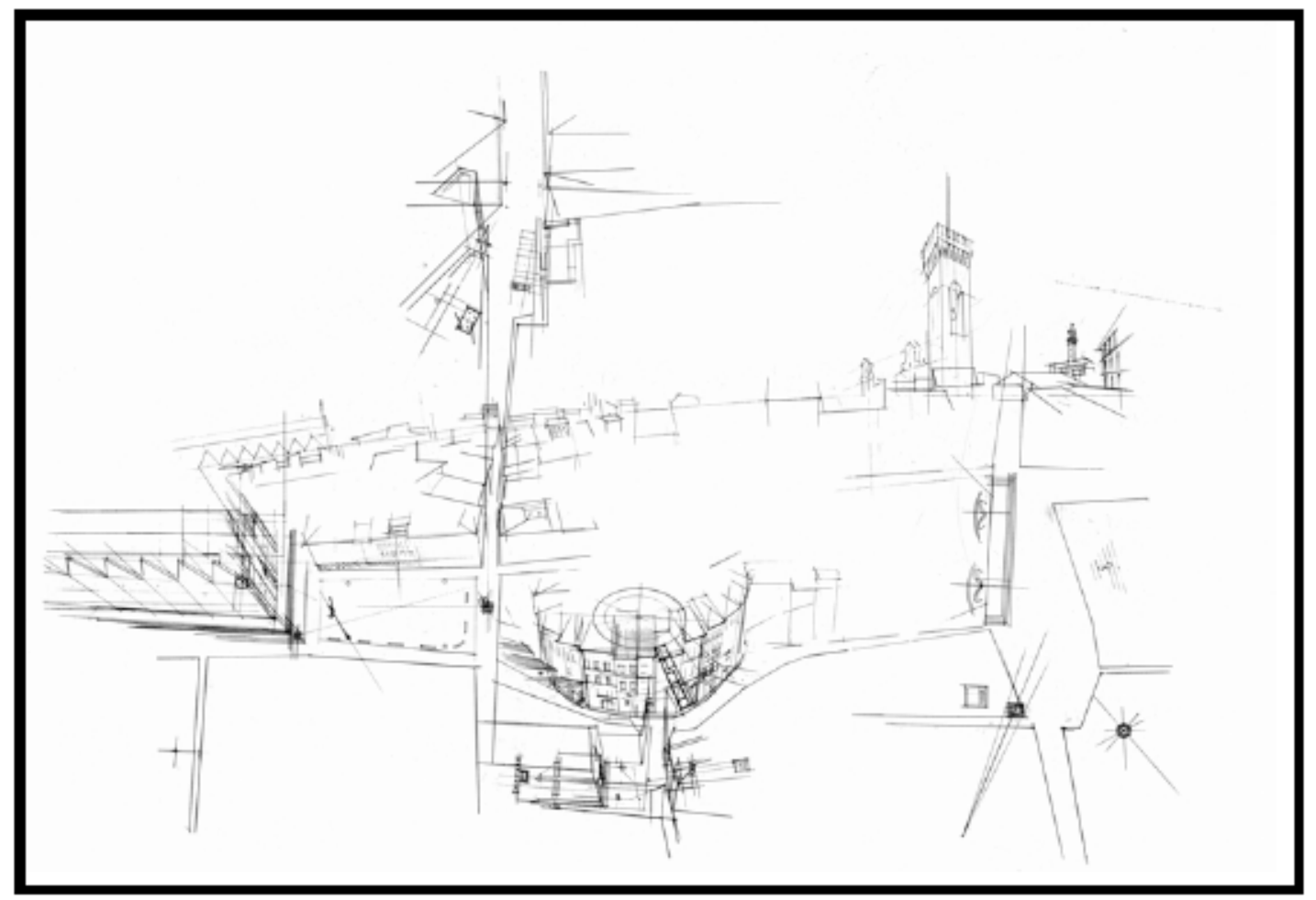

Figure 36: Perceptive map by Andrea Ponsi

${ }^{107}$ Idem. 


\section{Visibility}

Centre Canadien Islamique AI Jamieh - WEST noun | vis-i-bil-i.ty | \, vi-zə-'bi-lə-te-\|

1 the quality or state of being visible

2 a : the degree of clearness (as of the atmosphere or ocean); specifically : the greatest distance through the atmosphere toward the horizon at which prominent objects can be identified with the naked eye

$\mathrm{b}$ : capability of being readily noticed

c: capability of affording an unobstructed view

d: publicity

3 a measure of the ability of radiant energy to evoke visual sensation

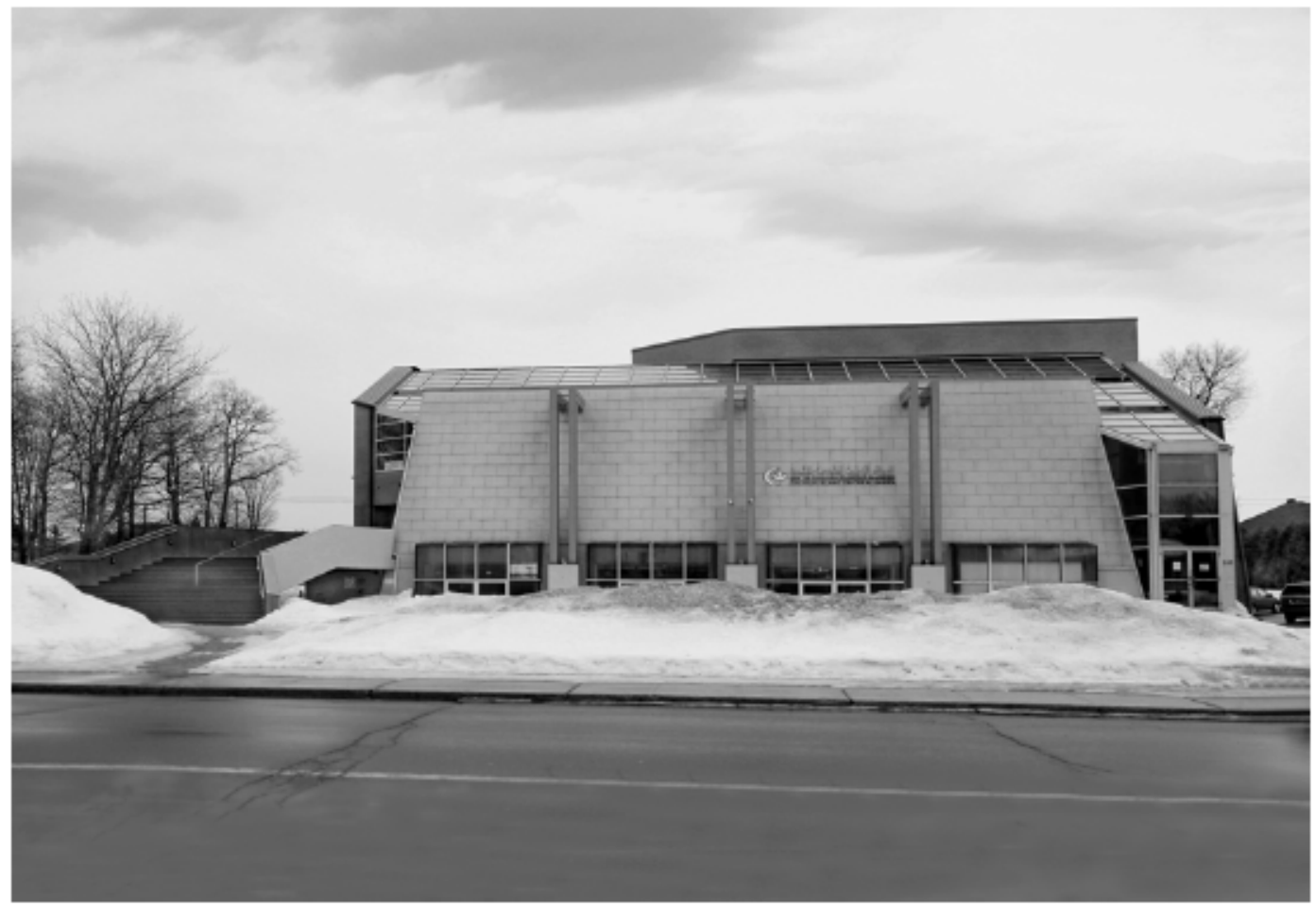


Visibility

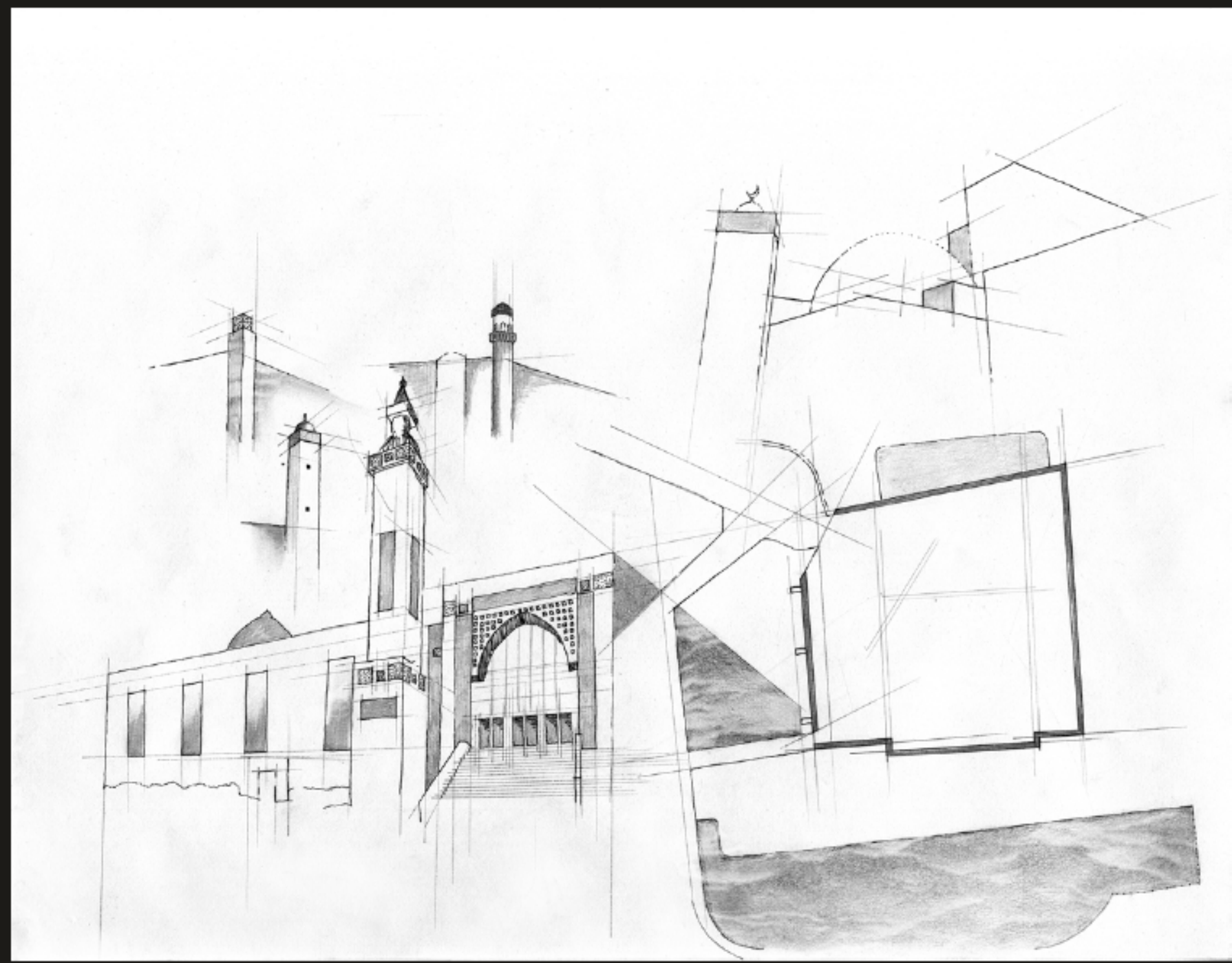

Respectable Sears matrons shake their heads and frown as they notice what my grandmother is doing,

an affront to American porcelain,

a contamination of American Standards

by something foreign and unhygienic

requiring civic action and possible use of disinfectant spray

They fluster about and flutter their hands and I can see

a clash of civilizations brewing in the Sears bathroom

Excerpt from My Grandmother Washes Her Feet in the Sink of the Bathroom at Sears, Mohja Kahf 


\section{Movement}

\section{Al-Rawdah mosque - NORTH noun | move-ment | \'müv-mənt \}

1 : the act or process of moving; especially: change of place or position or posture

2 : tendency, trend $b$ : a series of organized activities working toward an objective; also : an organized effort to promote or attain an end 3 : the moving parts of a mechanism that transmit a definite motion $4 \mathrm{a}$ : motion $\mathrm{b}$ : the rhythmic character or quality of a musical composition c: a distinct structural unit or division having its own key, rhythmic structure, and themes and forming part of an extended musical composition d: particular rhythmic flow of language: cadence $5 \mathrm{a}$ : the quality (as in a painting or sculpture) of representing or suggesting motion $b$ : the vibrant quality in literature that comes from elements that constantly hold a reader's interest (such as a quickly moving action- filled plot)

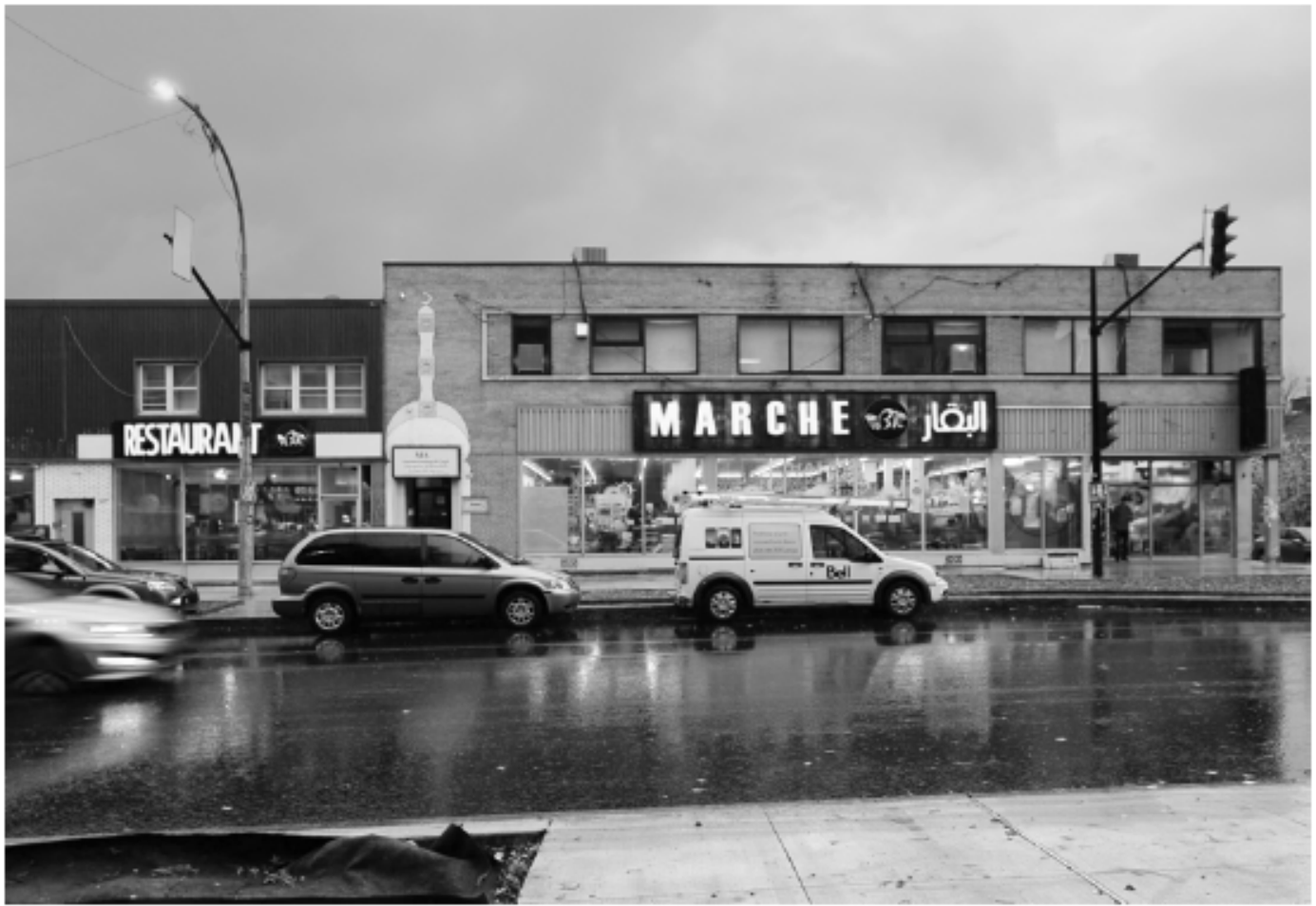




\section{Movement}

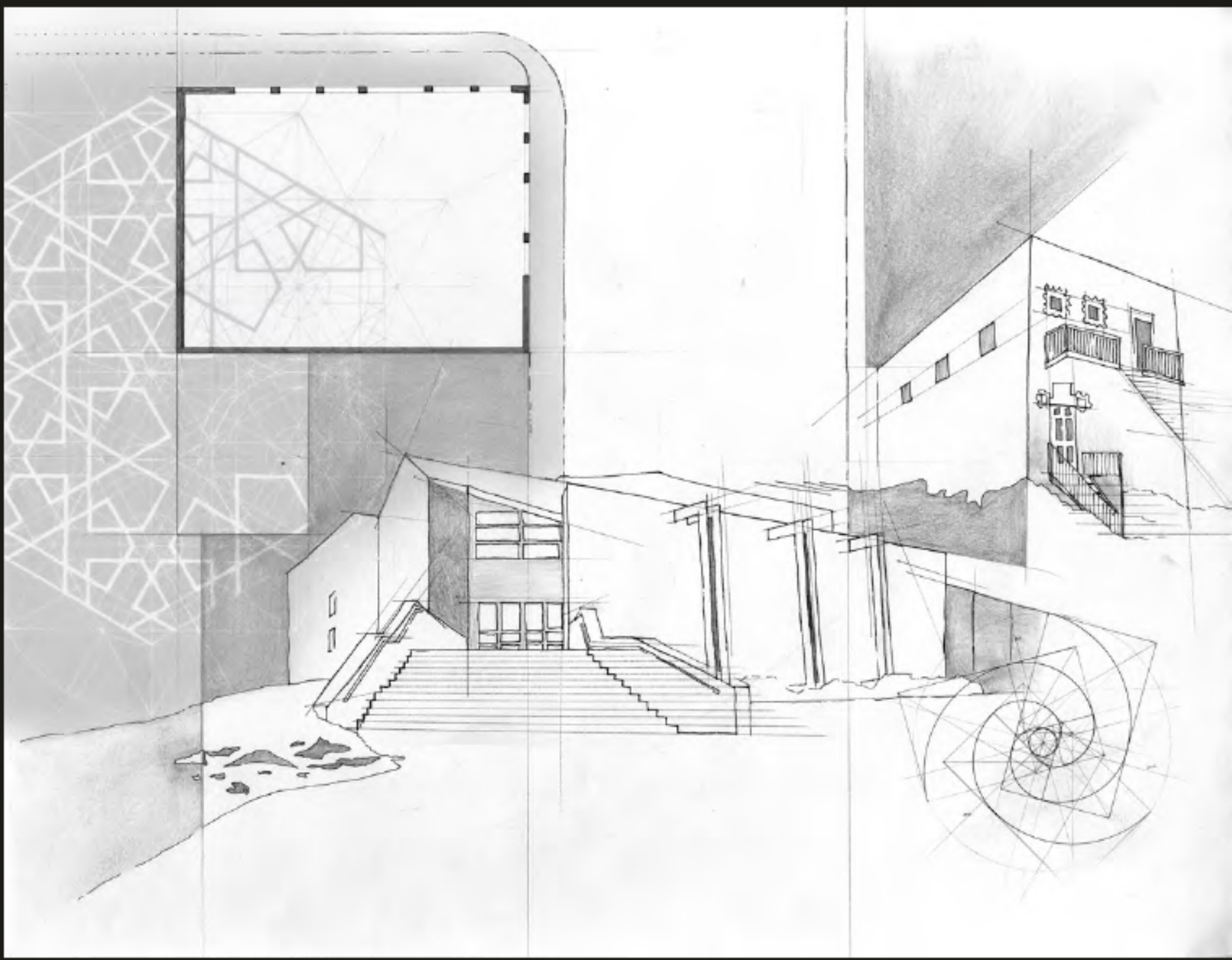

The emerald mosque upon the hill built around a flowing spring the easy absolutions and ablutions in that mosque where the spring water has been let loose to meander over marble courtyards and inner chambers across the geometric, green-tiled floor that cools the heels of the faithful

\section{Excerpt from The Emerald Mosque on the Hill,} Raza Ali Hasan 


\section{Opacity}

\section{Centre Ach-Choura - EAST Noun | opac-i.ty | $\mid$ o-'pa-sə-te- |}

$1 \mathrm{a}$ : obscurity of sense : unintelligibility $\mathrm{b}$ : the quality or state of being mentally obtuse: dullness

2 the quality or state of a body that makes it impervious to the rays of light; broadly : the relative capacity of matter to obstruct the transmission of radiant energy

3 an opaque spot in a normally transparent structure (such as the lens of the eye)

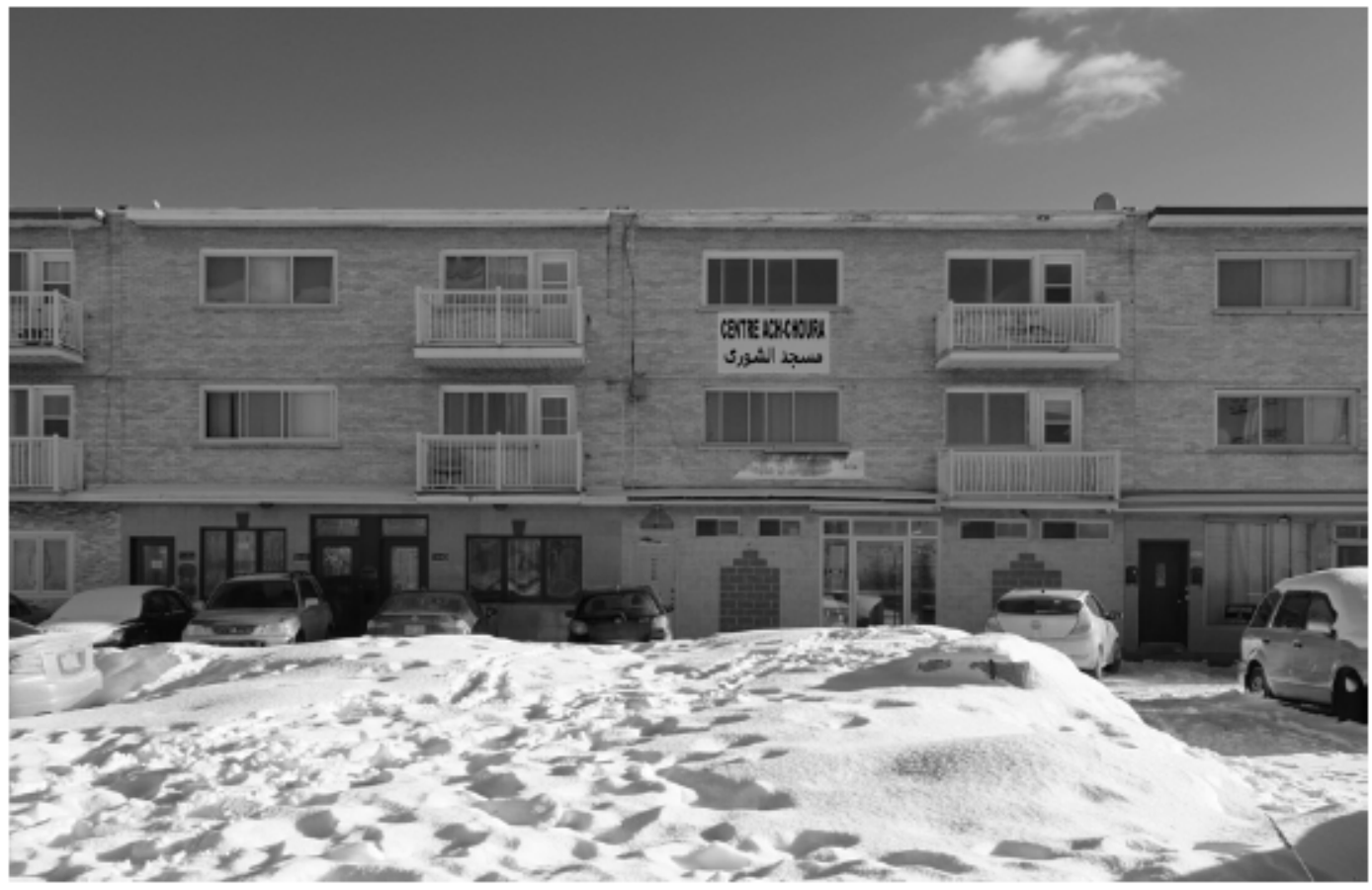




\section{Opacity}

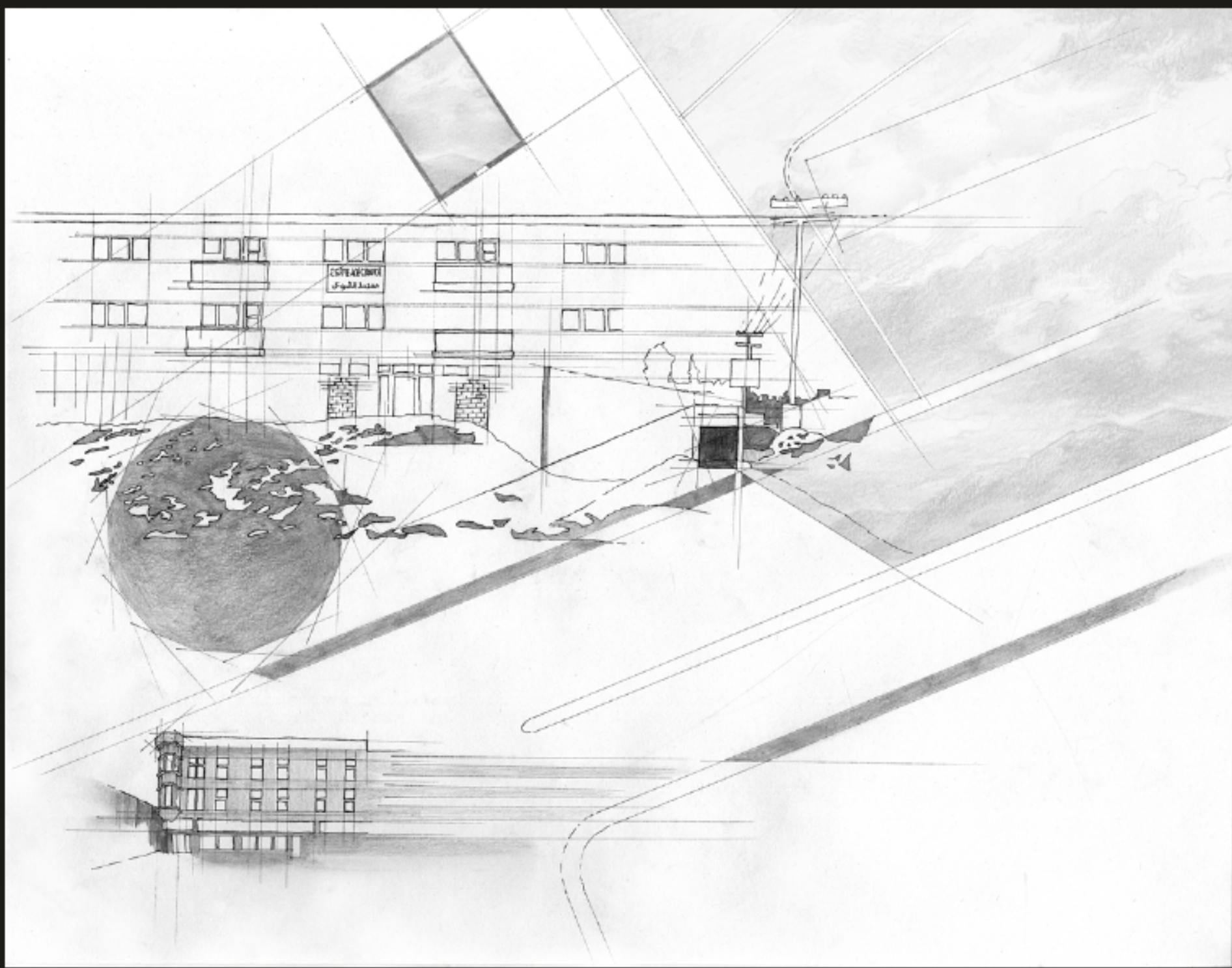

Some prized the pilgrimage, wrapping themselves in new white linen

to ride buses across miles of vacant sand.

When they arrived at Mecca

they would circle the holy places,

on foot, many times,

they would bend to kiss the earth

and return, their lean faces housing mystery.

\section{Excerpt from Different Ways to Pray,}

Naomi Shihab Nye 


\section{Threshold}

\section{Al-Omah Al-Islamiah Mosque - CENTRE \\ Noun | thresh-old | I'thresh-, hold , 'thre-, shold I}

1 the plank, stone, or piece of timber that lies under a door; sill

2 a: gate, door

b (1) : end, boundary; specifically : the end of a runway (2): the place or point of entering or beginning: outset

$3 \mathrm{a}$ : the point at which a physiological or psychological effect begins to be produced

$b$ : a level, point, or value above which something is true or will take place and below which it is not or will not

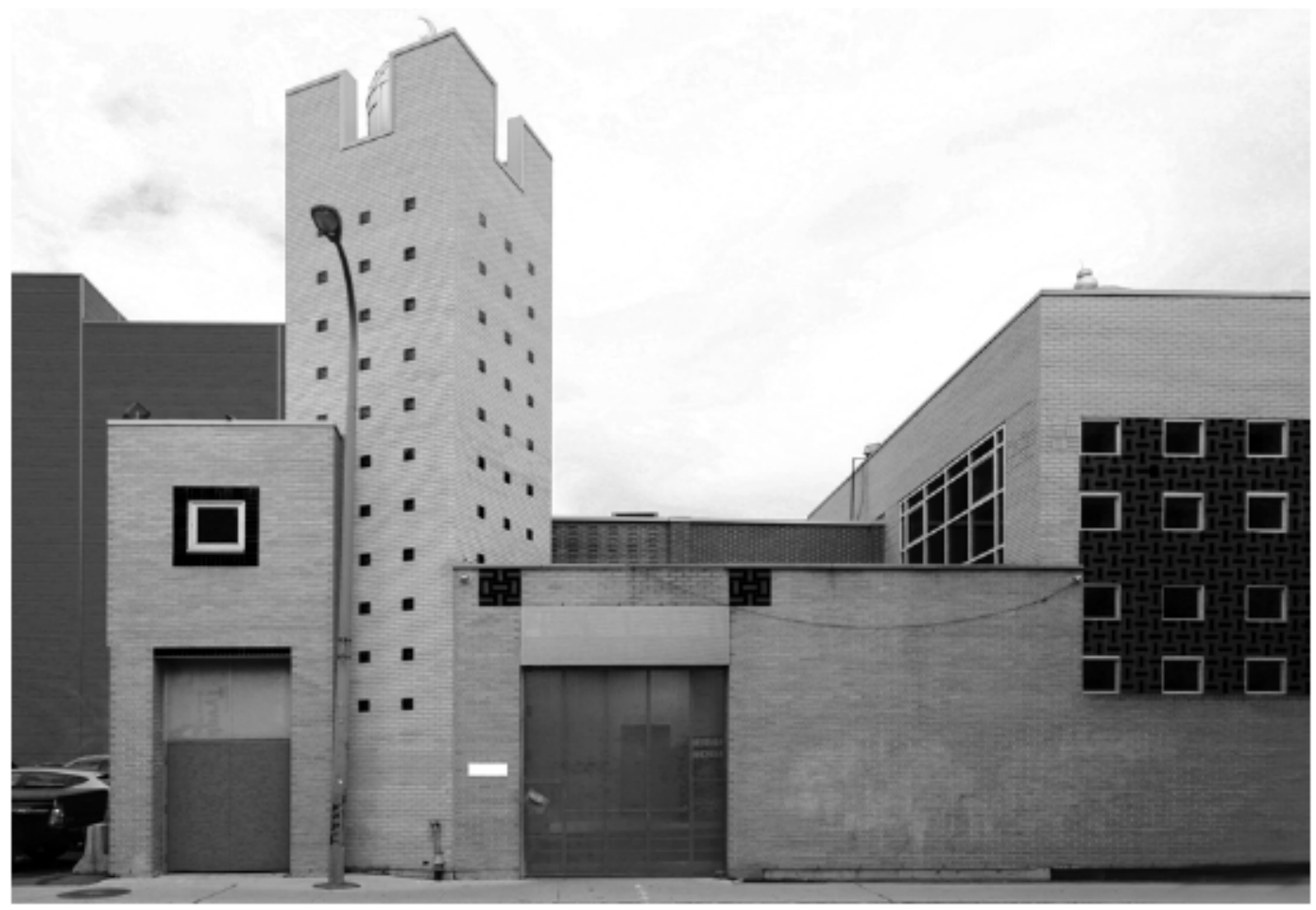




\section{Threshold}

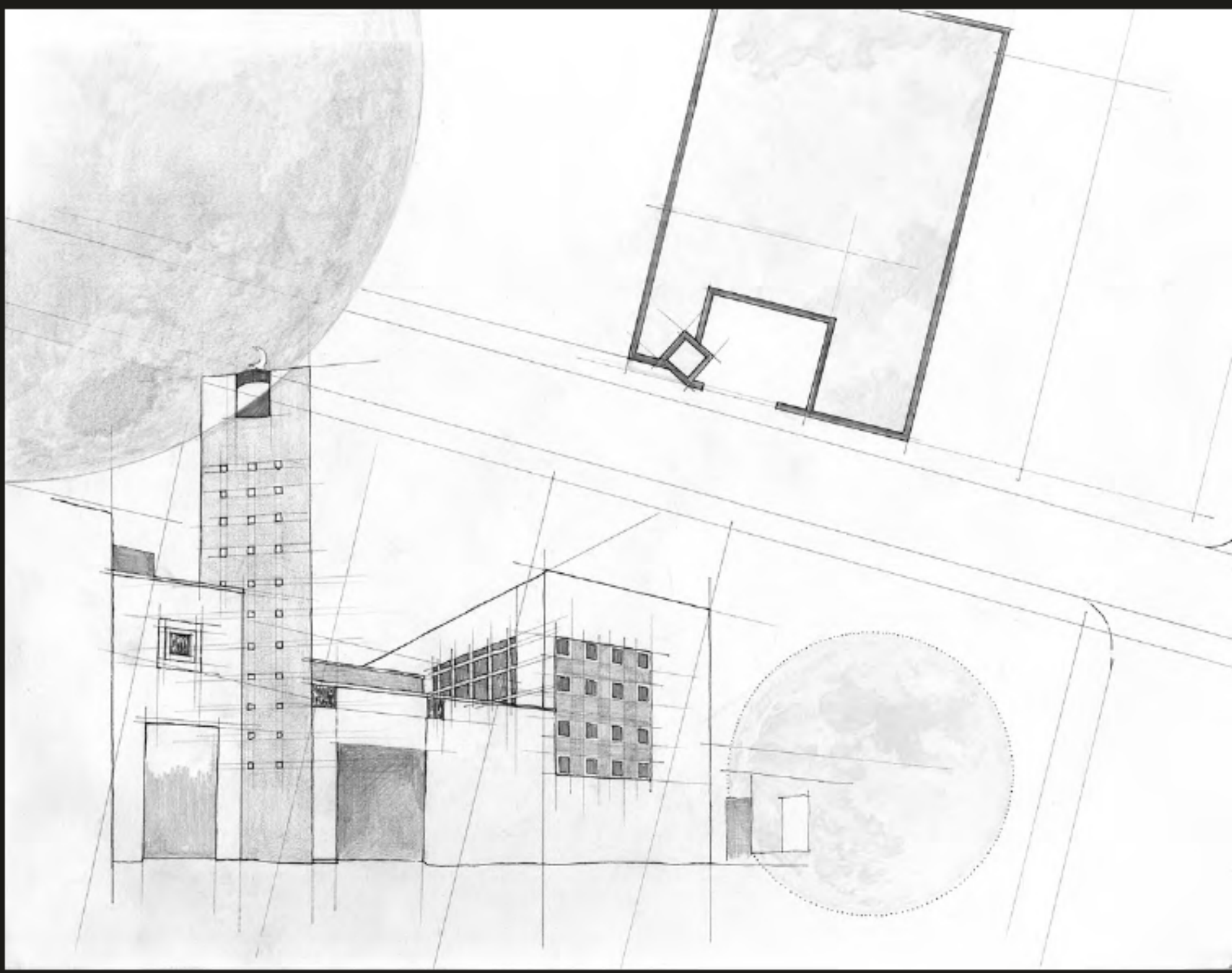

This month the moon becomes a princess.

The stars fan her,

Jupiter pours cups of wine,

Mars sings melancholy mawals.

Bearded men holding prayer beads

and yellow booklets stare at her

and point aching fingers at her waist.

In our house we break a fast.

\section{Excerpt from Ramadan,}

Khaled Mattawa 


\section{Façade}

Islamic Centre of Verdun - SOUTH Noun | fa-cade | \fə-'säd |

1: the front of a building; also : any face of a building given special architectural treatment

2: a false, superficial, or artificial appearance or effect

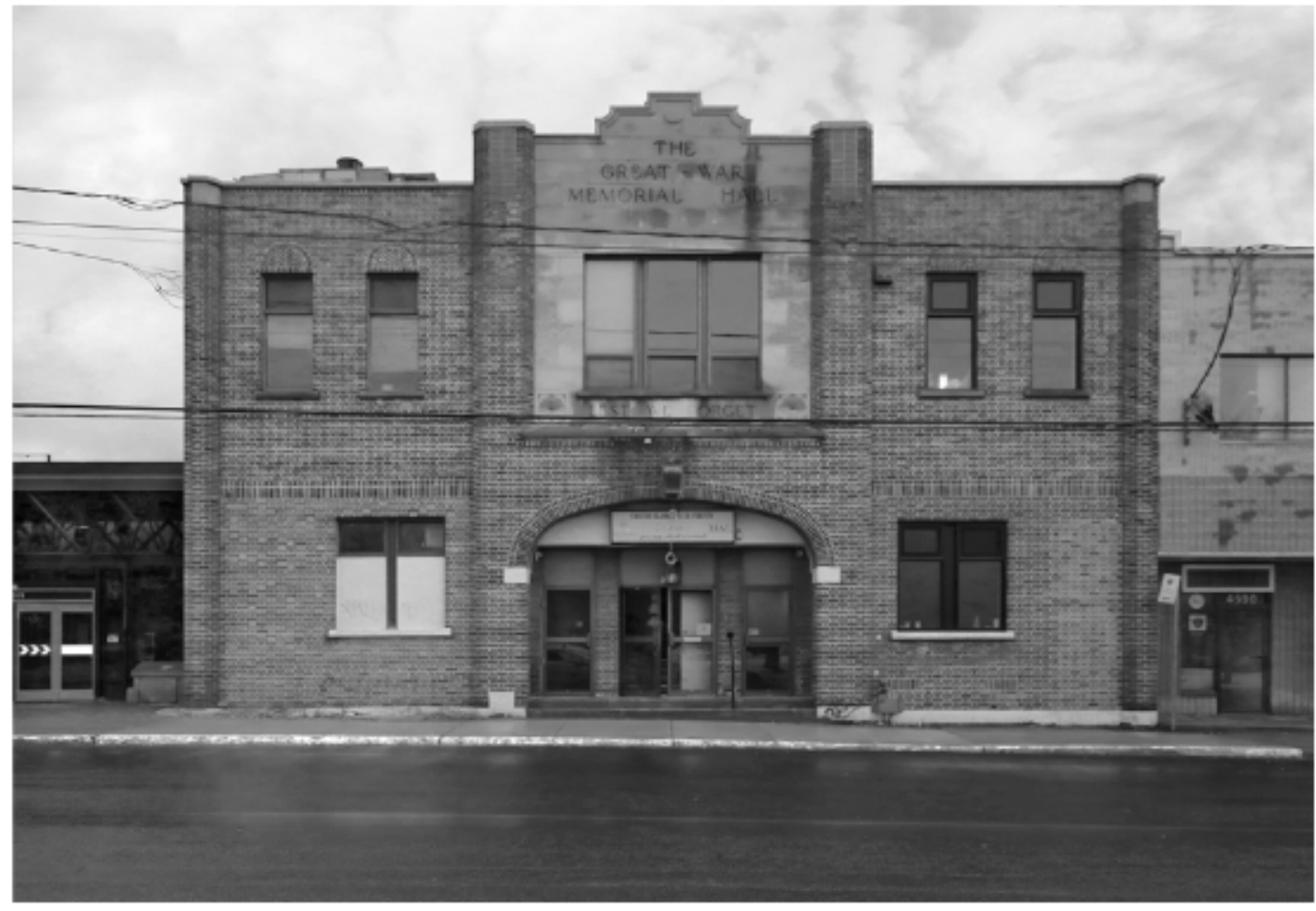




\section{Façade}

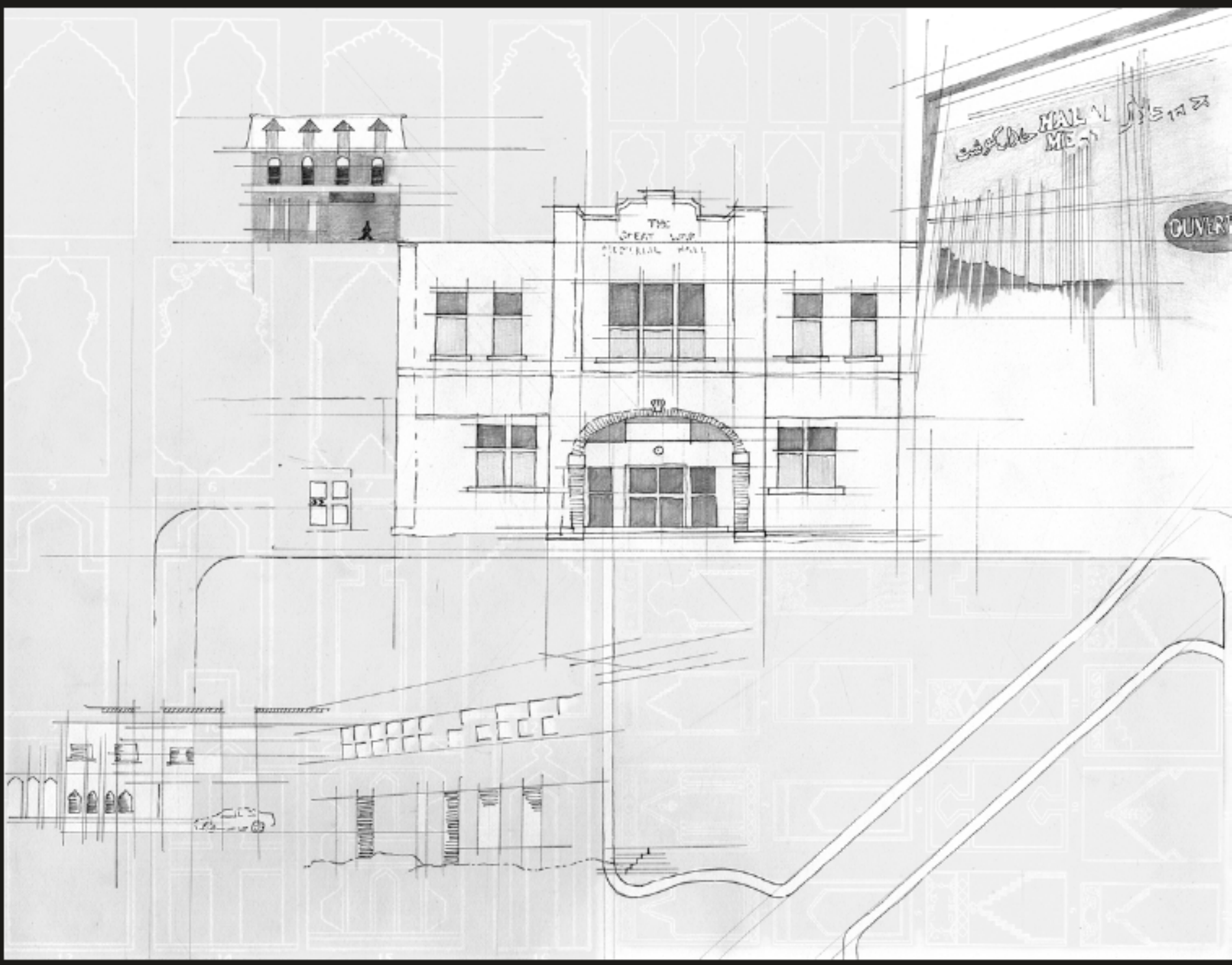

Those intervals

between the day's

five calls to prayer

in those intervals this rug

part of Grandma's dowry

folded.

And then the sunset

call to prayer

Excerpt from Prayer Rug,

Agha Shahid Ali 
国

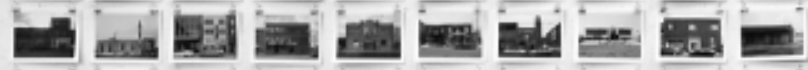

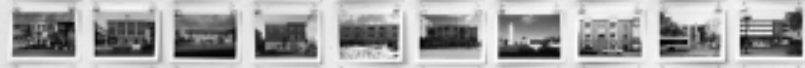

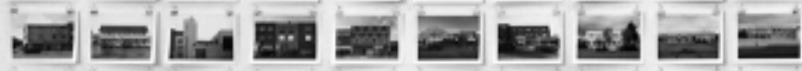

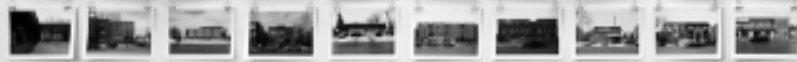

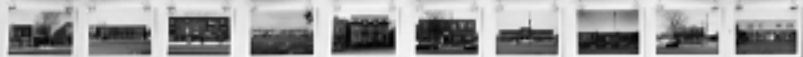

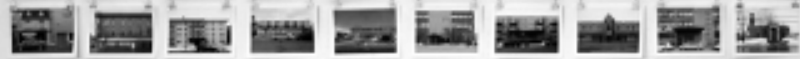
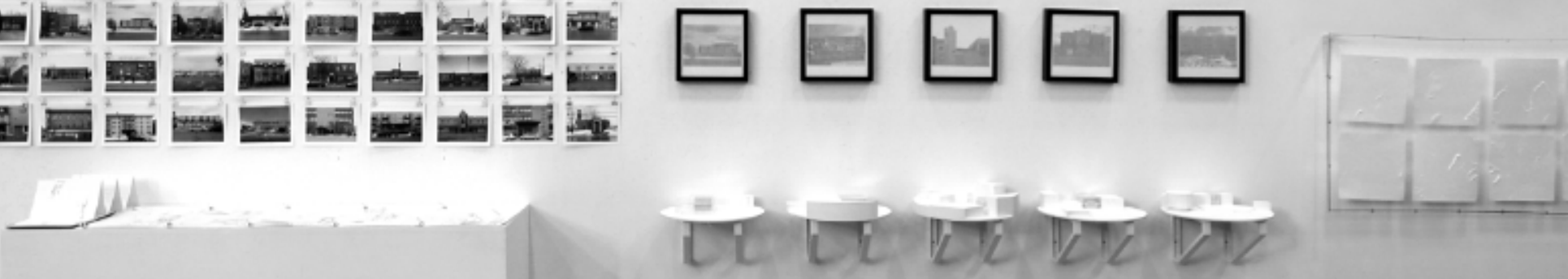

Figure 42: Thesis defence 


\section{Design Reflections}

An early intention for this thesis was to explore ways to make religious spaces visible, to take them into the public space through design and art. By highlighting the presence of this concealed illuminated city, this atlas constitutes a step in the direction of bridging the gap that sometimes exists between Muslim communities and some of their neighbours. By putting an emphasis on visibility and recognition, I tried to overcome the current tendency to "make invisible" or to "purposely ignore to acknowledge" these spaces. As geographer Bochra Manaï states, leaving its mark in a city allows a community to feel a sense of belonging. ${ }^{108}$

As mentioned above, the research project was imagined in reaction to the political events of the past decade in the province of Quebec. This thesis intended to dig a bit deeper than what is usually being conveyed about Islam and Islamic spaces by acknowledging the common tropes - such as the veil, the concealing, the aniconism, etc. - and then by going further.

Another early intention was to try to find ways, through architecture, to make up for past wrongs. In other words, I wanted to explore new ways to think about how architects can address culture, heritage,

${ }^{108} 2015$, p. 141 
and cultural needs in their designs, and, eventually, think about what would an "architecture of reconciliation" be. The following are some arguments I found compelling.

First, designers and urban planners should avoid what Germain et al. call a desire to "pasteurize" public spaces ${ }^{109}$, which consists in the belief that the best way to plan and design public spaces that foster the peaceful coexistence of differences is to try to provide a neutral space - a belief, the authors note, that is especially marked when it comes to the issue of religious identity. In the same line of thinking, what geographer Ash Amin calls "assimilationist ideals" should be avoided at all cost. As Amin states, "mixed neighbourhoods need to be accepted as the spatially open, culturally heterogeneous and socially variegated spaces that they are, not imagined as future cohesive or integrated communities."110 Failing to do so, "eschewing contact and refusing to allow the interaction of diverse cultures in public places and in our urban landscapes, are the first steps toward urban fragmentation."111

Second, urban planners can perfect their ability to innovate and their contribution to social cohesion by reconciling places of

\footnotetext{
${ }^{109} 2008$, p. 157

1102002 , p. 972

"11 Germain and Gagnon 2003, p. 91
} 
worship with their environment. In the words of Germain and Gagnon,

Combining related community activities and places for prayer can benefit the entire neighbourhood and can be a catalyst for integration if these services are made available to everyone. Public spaces, much like public places, streets and parks-as places of social exchange and interaction, as well as a stage for cultural and religious diversity-must be nurtured through careful planning that avoids overcharging the social arena. Immigrants are usually frequent users of public spaces and, as such, contribute to the vitality of the urban landscape.

Finally, planners need to acknowledge arguments denouncing prejudices such as the point on the whiteness of space made by Ahmed and Wilkins. I believe that it is erroneous to think that spaces can and should be neutral, since they are inhabited by people who are not. Trying to "purge" the public space from all its symbolic markers is not only pointless, but it might also have the unintended perverse effect to reproduce certain inequalities that already exist.

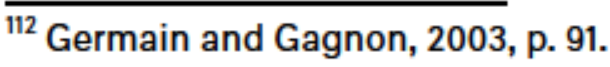




\section{Conclusion}

The Illuminated City attempts to reveal a hidden-in-plain-sight landscape, to ensure visibility and recognition to religious spaces that are too often the target of prejudice and hatred.

Why have I decided not to design a sacred space myself? I have come to the realization that, as a non-Muslim, it would be very difficult to envision a place of worship without first studying the context in-depth, an opportunity that this year of thesis offered me. Too often the practice of architecture and urban planning reproduce a neo-colonialist attitude, and it was thus a relief to decide to observe, document, and analyze rather than physically intervene in the environment.

Instead, this project allows for multiple narratives to emerge through the superimposition of speculative sections, illuminated models, itineraries mapping, and experiential drawings. By doing so, I hope it invited the reader to make their own story and rendered the illuminated city tangible. 


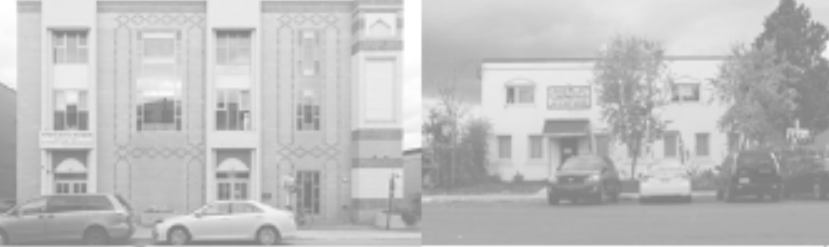

F c

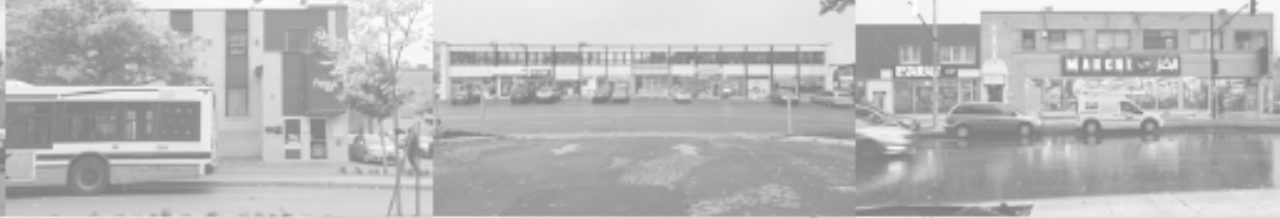
II II tis ivin in In $1 \mathrm{n}$ (a)

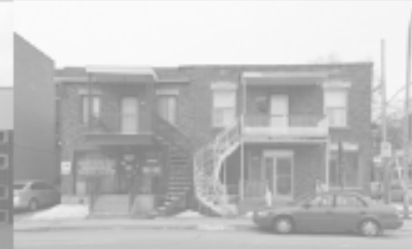
1. Qeall

$\lim _{0} \operatorname{lin}_{2}$

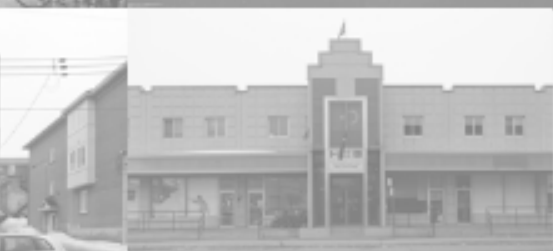

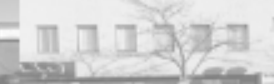

(1)

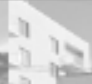

to

समतनेको

7.

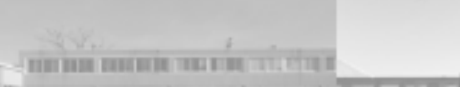

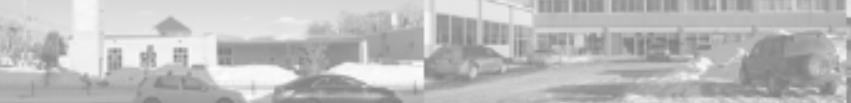

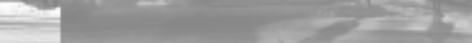

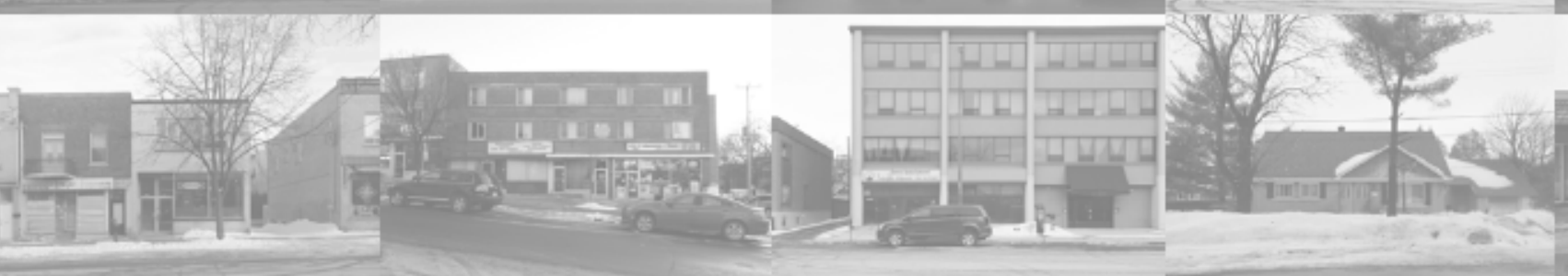

$\sqrt{1} \sqrt{7}=$

(1-nistif

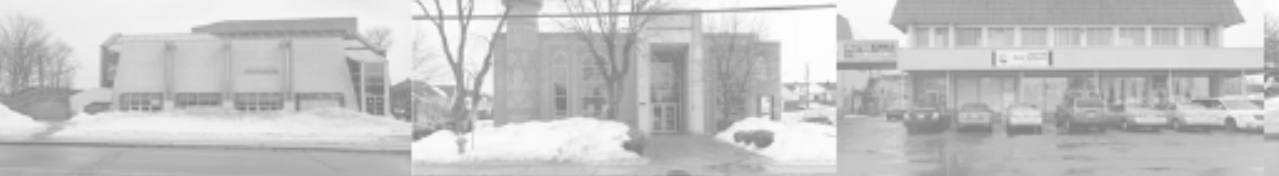
tranger 西

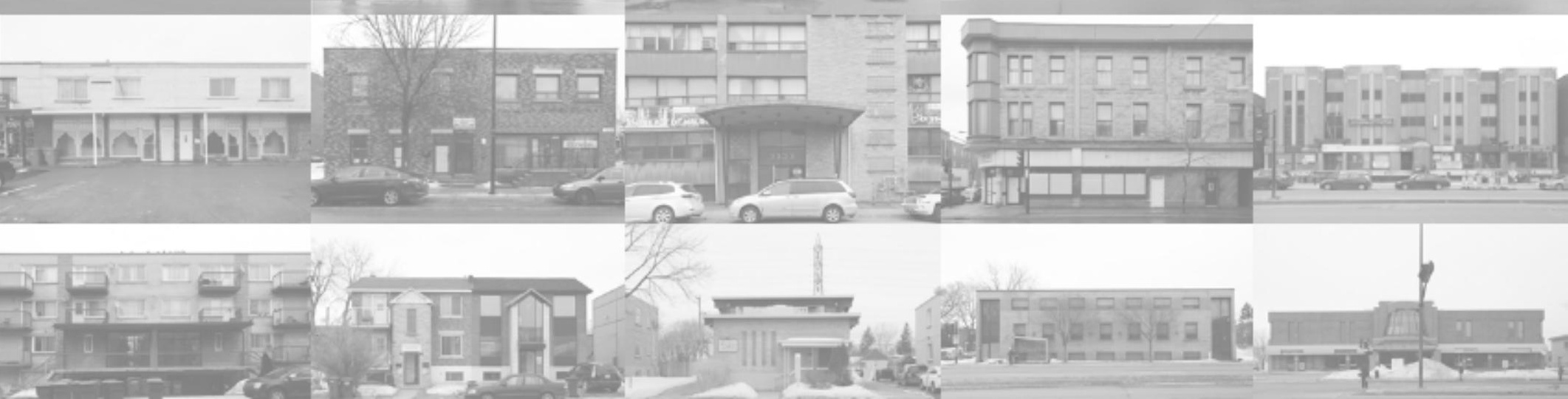


Appendix 1

\title{
My Grandmother Washes Her Feet in the Sink of the Bathroom at Sears
}

\author{
By Mohja Kahf
}

My grandmother puts her feet in the sink of the bathroom at Sears to wash them in the ritual washing for prayer, wudu, because she has to pray in the store or miss the mandatory prayer time for Muslims She does it with great poise, balancing herself with one plump matronly arm against the automated hot-air hand dryer, after having removed her support knee-highs and laid them aside, folded in thirds, and given me her purse and her packages to hold so she can accomplish this august ritual and get back to the ritual of shopping for housewares

Respectable Sears matrons shake their heads and frown as they notice what my grandmother is doing, an affront to American porcelain, a contamination of American Standards by something foreign and unhygienic requiring civic action and possible use of disinfectant spray They fluster about and flutter their hands and I can see a clash of civilizations brewing in the Sears bathroom

My grandmother, though she speaks no English, catches their meaning and her look in the mirror says, I have washed my feet over Iznik tile in Istanbul with water from the world's ancient irrigation systems I have washed my feet in the bathhouses of Damascus over painted bowls imported from China

among the best families of Aleppo And if you Americans knew anything about civilization and cleanliness, you'd make wider washbins, anyway My grandmother knows one culture-the right one,

as do these matrons of the Middle West. For them, my grandmother might as well have been squatting in the mud over a rusty tin in vaguely tropical squalor, Mexican or Middle Eastern, it doesn't matter which, 
when she lifts her well-groomed foot and puts it over the edge.

"You can't do that," one of the women protests, turning to me, "Tell her she can't do that."

"We wash our feet five times a day,"

my grandmother declares hotly in Arabic.

"My feet are cleaner than their sink.

Worried about their sink, are they? I

should worry about my feet!"

My grandmother nudges me, "Go on, tell them."

Standing between the door and the mirror, I can see

at multiple angles, my grandmother and the other shoppers, all of them decent and goodhearted women, diligent in cleanliness, grooming, and decorum

Even now my grandmother, not to be rushed, is delicately drying her pumps with tissues from her purse For my grandmother always wears well-turned pumps that match her purse, I think in case someone from one of the best families of Aleppo should run into her-here, in front of the Kenmore display

I smile at the midwestern women as if my grandmother has just said something lovely about them and shrug at my grandmother as if they had just apologized through me No one is fooled, but I

hold the door open for everyone and we all emerge on the sales floor and lose ourselves in the great common ground of housewares on markdown. 
Appendix 2

The Emerald Mosque on the Hill

By Raza Ali Hasan

In the lull, the afternoon sun warms

the linseed field. The flowers are quiet,

their bright subdued in the green

while the mind wanders

to the emerald mosque upon the hill, built around a flowing spring,

the easy absolutions and ablutions

in that mosque where the spring water

has been let loose to meander

over marble courtyards and inner chambers,

across the geometric, green-tiled floor that cools the heels of the faithful. 
Appendix 3

\title{
Different Ways to Pray
}

\author{
By Naomi Shihab Nye
}

There was the method of kneeling, a fine method, if you lived in a country where stones were smooth.

The women dreamed wistfully of bleached courtyards, hidden corners where knee fit rock.

Their prayers were weathered rib bones, small calcium words uttered in sequence, as if this shedding of syllables could somehow fuse them to the sky.

There were the men who had been shepherds so long they walked like sheep.

Under the olive trees, they raised their arms-

Hear us! We have pain on earth!

We have so much pain there is no place to store it!

But the olives bobbed peacefully

in fragrant buckets of vinegar and thyme.

At night the men ate heartily, flat bread and white cheese, and were happy in spite of the pain, because there was also happiness.

Some prized the pilgrimage, wrapping themselves in new white linen to ride buses across miles of vacant sand.

When they arrived at Mecca they would circle the holy places, on foot, many times,

they would bend to kiss the earth and return, their lean faces housing mystery.

While for certain cousins and grandmothers the pilgrimage occurred daily, lugging water from the spring or balancing the baskets of grapes.

These were the ones present at births, humming quietly to perspiring mothers.

The ones stitching intricate needlework into children's dresses, forgetting how easily children soil clothes.

There were those who didn't care about praying. 
The young ones. The ones who had been to America. They told the old ones, you are wasting your time.

Time?-The old ones prayed for the young ones.

They prayed for Allah to mend their brains, for the twig, the round moon, to speak suddenly in a commanding tone.

And occasionally there would be one who did none of this, the old man Fowzi, for example, Fowzi the fool, who beat everyone at dominoes, insisted he spoke with God as he spoke with goats, and was famous for his laugh. 
Appendix 4

\section{Ramadan}

By Khaled Mattawa

My mother forgets to feed her animals

because it's only fair.

She rushes to them when

she hears hoarse roosters crowing

and billy goats butting

over a last straw.

This month the moon becomes a princess.

The stars fan her, Jupiter pours cups of wine, Mars sings melancholy mawals.

Bearded men holding prayer beads

and yellow booklets stare at her

and point aching fingers at her waist.

In our house we break a fast

with dates from Huun

and glasses of buttermilk.

Then on to bowls of lamb soup

flavored with mint, trays

of stuffed grape leaves, spiced fava beans drenched

in olive oil and lemon juice.

And that is only the beginning.

The spirits of Johnny Walker and gin hide in the trunks of white Peugeots. In the nightclubs of my city, waiters serve only non-alcoholic beer and belly dancers cover themselves.

Father of sixteen children, our neighbor visits bringing two kilos of baklava.

He washes them down with a dozen demitasses of sweet sage tea.

Before dawn he runs to one of his two wives, both named Salma, and loves her hurriedly, his hands barely touching a breast. 
Appendix 5

\section{Prayer Rug}

By Agha Shahid Ali

Those intervals

between the day's

five calls to prayer

the women of the house

pulling thick threads

through vegetables

rosaries of ginger

of rustling peppers

in autumn drying for winter

in those intervals this rug part of Grandma's dowry

folded

so the Devil's shadow would not desecrate Mecca scarlet-woven

with minarets of gold but then the sunset call to prayer

the servants

their straw mats unrolled

praying or in the garden

in summer on grass

the children wanting

the prayers to end

the women's foreheads

touching Abraham's

silk stone of sacrifice

black stone descended

from Heaven

the pilgrims in white circling it 
this year my grandmother also a pilgrim

in Mecca she weeps

as the stone is unveiled she weeps holding on to the pillars 


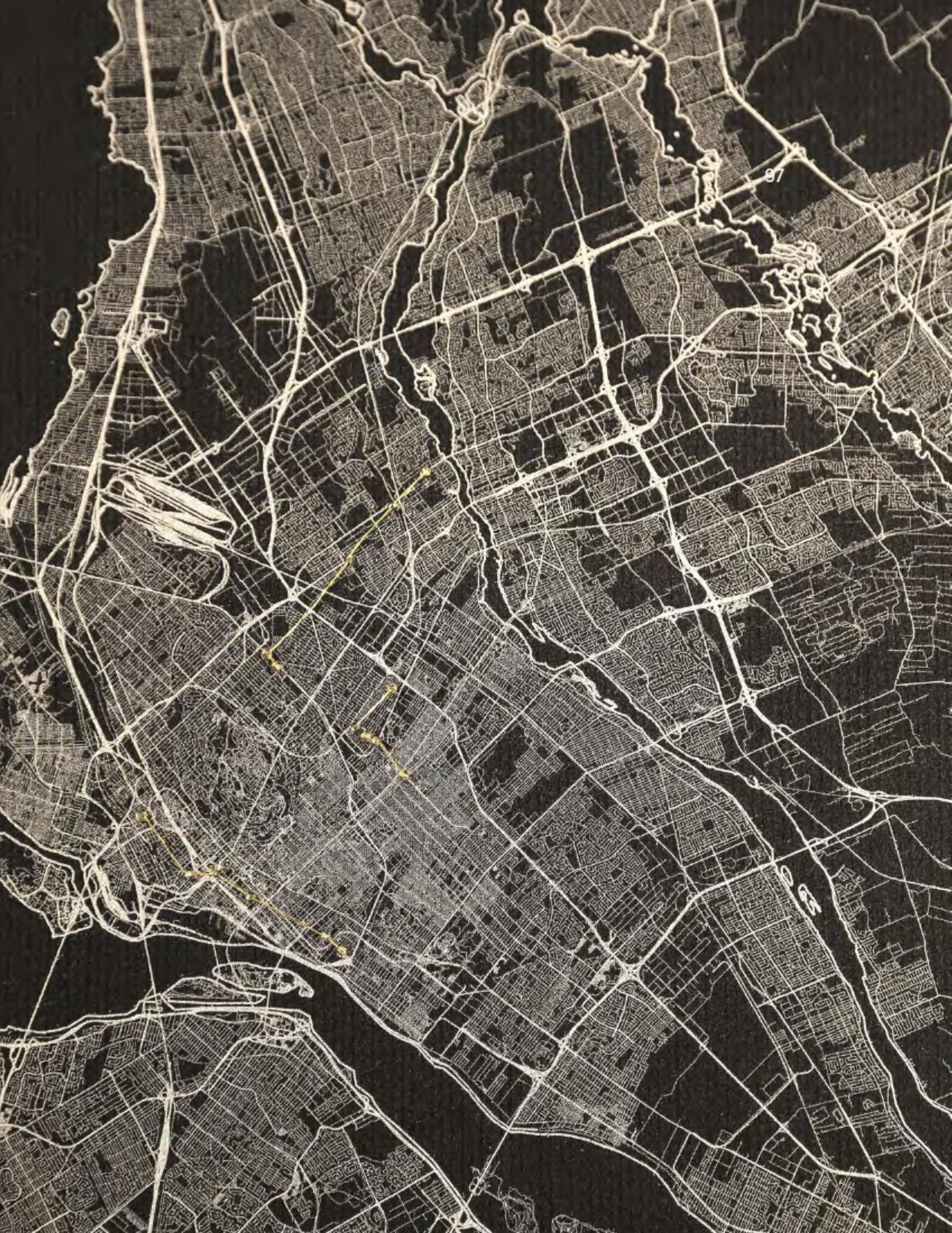




\section{Text Sources}

Ahmed, Sara. 2007. "A Phenomenology of Whiteness," in Feminist Theory, vol. 8 (2), pp. 149-168.

Asad, Talal. 2003. Formations of the Secular: Christianity, Islam, Modernity. Stanford University Press.

Amin, Ash. 2002. "Ethnicity and the multicultural city. Living with diversity," in Environment and Planning A, 34, pp. 959-980.

Balibar, Étienne. 1997, "Y a-t-il un néo-racisme?" in Race, Nation, Classe. Les identités ambigües (2d edition). Éditions La Découverte, pp. 27-41.

Balibar, Étienne. 2006. "Différence, altérité, exclusion : trois catégories anthropologiques pour théoriser le racism", in Parizeau, Marie-Hélène \& Soheil Kash (Êds.). Néoracisme et dérives génétiques. Les Presses de l'Université Laval. pp. 27-45.

Berger, John. 1980. "Uses of Photography." About Looking, Pantheon (NY), pp. 48-63.

Brighenti, Andrea. 2007. "Visibility." In Current Sociology, 55 (3): pp. 323-342.

Britton, Karla Cavarra (ed.). 2010. "Introduction," in Constructing the Ineffable: Contemporary Sacred Architecture, Yale University Press, pp. 8-11.

Calhoun, Craig, et al, eds. 2011. Rethinking Secularism. Oxford and New York: Oxford University Press.

Chidester, David. 2011. “Sacred”, in Material Religion, 7:1, pp. 84-90.

Gagnon, Monika Kin and Yasmin Jiwani. 2012. "Amplifying Threat: Reasonable Accommodations and Quebec's Bouchard-Taylor Commission Hearings (2007)," in S. Kamboureli and R. Zacharias (Eds.) Shifting the Ground of Canadian Literary Studies, (pp. 129149). Wilfred Laurier University Press.

Germain, Annick. 2010. Religion in Public Space in a Multi-Ethnic Environment: Reasonable Accommodations in Zoning ", in Le Pont/The Bridge, January 11, pp. 89-91. 
Germain, Annick, and Julie Elizabeth Gagnon. 2003. "Minority Places of Worship and Zoning Dilemmas in Montréal." Planning Theory and Practice 4.3, pp. 295-318.

Germain, Annick, Laurence Liégeois and Heidi Hoernig. 2008. "Les espaces publics en contexte multiethnique. Religion, visibilité et pasteurisation," in Les nouveaux territoires de l'ethnicité, Presses de 'Université Laval, p. 157-181.

Habermas, Jürgen. 1989. The Structural Transformation of the Public Sphere: An Inquiry Into a Category of Bourgeois Society. MIT Press.

Honneth, Axel. 2001. "Invisibility: On the Epistemology of 'Recognition'," Aristotelian Society Supplementary Volume, Volume 75, Issue 1, 1 July 2001, pp. 111-126.

Lang, Jon. 1994. Urban Design: The American Experience. John Wiley \& Sons, inc.

Langford, Martha. 2007. Scissors, Paper, Stone. Expressions of Memory in Contemporary Photographic Art. McGill-Queen's University Press.

Lefebvre, Henri. 1991.The Production of Space. Blackwell Publishing.

Lefebvre, Henri. 2008. Critique of Everyday Life: Volume 3. Verso Books.

Lu, Peter J., and Paul J. Steinhardt. 2007. "Decagonal and Quasicrystalline Tilings in Medieval Islamic Architecture." Science 315, pp. 1106-1110.

Mahmood, Saba. 2015. Religious Difference in a Secular Age. A Minority Report. Princeton University Press.

Manaï, Bochra. 2015. La "mise en scène" de l'ethnicité maghrébine à Montréal, PhD thesis, INRS / UQAMM. Accessed January 15, 2018, chromeextension://oemmndcbldboiebfnladdacbdfmadadm/http://espace.i nrs.ca/3313/1/Manai-B-D-Septembre2015.pdf

McAndrew, Marie. 2012. "The Reasonable Accommodation Controversy in Quebec: Asset or Obstacle to Intercultural Rapprochement?", in The St. Louis Era : Looking Back, Moving Forward. Selected Conference Proceedings. League for Human Rights, pp. 60-68. 
Metcalf, Barbara D., (ed). 1996. Making Muslim Space in North America and Europe. University of California Press.

Rousseau, Louis, (ed). 2012. Le Québec après Bouchard-Taylor. Les identités religieuses de l'immigration. Presses de l'Université du Québec.

Said, Edward W. 1978. Orientalism. Pantheon Books.

Scott, Joan Wallach. 2007. The Politics of the Veil. Princeton:

Princeton University Press.

Sharify-Funk, Meena and Elysia Guzik. 2017. "Muslim Veiling and the Legacy of Laîcité." In Everyday Sacred: Religion in Contemporary Quebec, edited by Hillary Kaell, McGill-Queen's University Press, pp. 186-211.

Sontag, Susan. 1973. "In Plato's Cave," in On Photography, New York: RosettaBooks, pp. 1-19.

Spivak, Gayatri Chakravorty. 1988. "Can the Subaltern Speak?" in Marxism and the Interpretation of Culture. Ed. Cary Nelson and Lawrence Grossberg. University of Illinois Press, pp. 271-313.

Taylor, Charles. 2011. "Why We Need a Radical Redefinition of Secularism", in Mendieta, Eduardo \& Jonathan Van Antwerpen, eds (2011). The Power of Religion in the Public Sphere. New York: Columbia University Press.

Tweed, Thomas A. 2011. "Space”, in Material Religion, 7:1, pp. 116123.

Ville de Montréal, Bureau des Affaires Interculturelles. 2000. Construire Ensemble. Orientations 2000-2001-2002. Interventions en Relations Interculturelles (Montréal).

Warner, Michael. 2002. "Publics and Counterpublics," in Public Culture, 14 (1): pp. 49-90.

Wilkins, Craig L. 2007. The Aesthetics of Equity, University of Minnesota Press, Minneapolis.

Živković, Milica. "The Double As The 'Unseen' Of Culture: Toward A Definition Of Doppelganger." Facta Universitatis 7, no. 2 (2000): 121128. 


\section{Web Sources}

Bdeir, Leila. "In the Name of Equality?" InspireSolutions, Dawsoncollege.qc.ca, November 13, 2013. Accessed September 20, 2017, https://inspire.dawsoncollege.qc.ca/2013/11/13/in-the-nameof-equality/

Bellerose, Patrick. "Denise Filiatrault: les femmes qui disent porter le voile par choix sont "des folles"." HuffingtonPost.ca, October 15, 2013. Accessed September 20, 2017, https://quebec.huffingtonpost.ca/2013/10/15/denise-filiatrault-lesfemmes-voilees-sont-\%20des-folles_n_4102192.html

Caron, Steve. "Un centre communautaire aux allures de mosquée dans Mercier." Journalmetro.com, February 9, 2015. Accessed November 1, 2017, http://journalmetro.com/local/mercieranjou/actualites/717673/prier-dans-lillegalite/

Esseghaier, Mariam, Audette-Longo, Trish, \& Lefebvre, Marie Eve. (Producers). (2014). Tout Cela Est...: Communicating the Charter of Quebec Values / Communiquer la Charte des valeurs québécoises [Documentary]. URL:

https://www.youtube.com/watch?v=ZRF7_7P0yNk [January 8, 2018].

"façade." Merriam-Webster.com. 2018. https://www.merriamwebster.com/dictionary/facade (22 January 2018).

"Francophone-Anglophone Relations."

TheCanadianEncyclopedia.ca. 2018. Accessed March 10, 2018, http://thecanadianencyclopedia.ca/en/article/francophoneanglophone-relations/

Gaber, Tammy. "Gendered Mosque Spaces," in Faith and Form, Volume 48, Issue 1. Accessed on January 22, 2018, http://faithandform.com/feature/gendered-mosque-spaces/

Haremst, Tilde. “'Touching' tiling." Spatial Experiments (course blog) Lund University, Department of Architecture and Built Environment. February 2, 2016, accessed December 22, 2017, https://spatialexperiments.wordpress.com/2016/02/02/touchingtiling/

Kilde, Jeanne H. "Sacred Space and Contested Terrain." TEDxUMN 2012, Youtube, accessed March 21, 2018,

https://www.youtube.com/watch?v=wul47gXGUvc 
Minsky, Amy. "Hate crimes against Muslims in Canada increase $253 \%$ over four years." Globalnews.ca, June 13, 2017. Accessed October 3, 2017, https://globalnews.ca/news/3523535/hate-crimescanada-muslim/

"movement." Merriam-Webster.com. 2018. https://www.merriamwebster.com/dictionary/movement

"opacity." Merriam-Webster.com. 2018. https://www.merriamwebster.com/dictionary/opacity (22 January 2018).

Ponsi, Andrea. "Perceptive Maps." StudioPonsi.it. Accessed February 22, 2018, https://studioponsi.it/perceptive-maps/

Proulx, Marie-Hélène. "Laïcité: non au voile." Chatelaine.com, December 2, 2013. Accessed September 20, 2017, http://fr.chatelaine.com/societe/entrevues/wassyla-tamzali/

"Révolution tranquille." TheCanadianEncyclopedia.ca. 2018. Accessed March 10, 2018, http://www.thecanadianencyclopedia.ca/fr/article/revolutiontranquille/

Shingler, Benjamin. "Decision to reject mosque in Ahuntsic not about Islamophobia, voters say." CBC News, June 7, 2016. Accessed January 22, 2018, http://www.cbc.ca/news/canada/montreal/ahuntsic-culturalcentre-mosque-referendum-1.3617932

Statistics Canada. "Police-reported hate crime, 2016." Statcan.gc.ca, November 28, 2017. Accessed December 1, 2017, https://www.statcan.gc.ca/daily-quotidien/171128/dq171128deng.htm

Stimson, Blake, "The Photographic Comportment of Bernd and Hilla Becher", Tate Papers, no.1, Spring 2004.

http://www.tate.org.uk/research/publications/tatepapers/01/photographic-comportment-of-bernd-and-hilla-becher, accessed 1 March 2018.

"threshold." Merriam-Webster.com. 2018. https://www.merriamwebster.com/dictionary/threshold (22 January 2018).

"visibility." Merriam-Webster.com. 2018. https://www.merriamwebster.com/dictionary/visibility (22 January 2018). 
Wells, Paul. “Jagmeet Singh's Quebec problem." Macleans.ca, July 11, 2017. Accessed November 3, 2017, http://www.macleans.ca/politics/ottawa/jagmeet-singhs-quebecproblem/

"Women's Suffrage in Canada." TheCanadianEncyclopedia.ca. 2018. http://www.thecanadianencyclopedia.ca/en/article/suffrage/ (10 March 2018) 


\section{Image Sources}

Fig. 01: Unknown, "La centrale hydroélectrique Manic-5, une voiture du métro de Montréal et l'Exposition universelle de 1967." Source: Wikimedia Commons, Digital image. Available from: fr.wikipedia.org/wiki/R\%C3\%A9volution_tranquille\#/media/File:Rev olutionTranquille_Montage.jpg (accessed January 30, 2018).

Fig. 02: Rémi Lemée, "Dix ans après la commission BouchardTaylor." Source: LaPresse.ca, Digital image. Available from: www.lapresse.ca/actualites/politique/201710/21/01-5140827-la-loi62-ne-passera-pas-le-test-des-tribunaux-selon-bouchard-ettaylor.php (accessed March 30, 2018).

Fig. 03: Ryan Remiorz, "Demonstrators protest against Quebec's proposed Values Charter." Source: The Canadian Press, Digital image. Available from: www.ucobserver.org/features/2013/12/gospel_secularism/ (accessed March 22, 2018).

Fig. 05: Reuters, "Thousands protest Quebec's proposed values charter." Source: Toronto Sun, Digital image. Available from: http://torontosun.com/2013/09/14/thousands-protest-quebecsproposed-values-charter/wcm/f1805aa4-48d5-4da5-9ab815a606a4ca6a (accessed September 29, 2017).

Fig. 06: Ames Lai, "Montreal in snow." Available from: www.flickr.com/photos/amesis/16234414336 (accessed March 4, 2018).

Fig. 07: Unknown, “Notre-Dame- de-la-Défense." Source: Petiteltalie.com, Digital image. Available from: www.petiteitalie.com/en/a-propos (accessed February 24, 2018).

Fig. 08: Chesiyuan, "Saint Joseph Oratory." Source: Wikimedia Commons, Digital image. Available from: commons.wikimedia.org/wiki/File:Saint_joseph_oratory_montreal_2 010q.JPG (accessed January 30, 2018).

Fig. 13: Bernd and Hilla Becher, "Pitheads." Source: Tate Museum, Digital image. Available from: www.tate.org.uk/art/artworks/berndbecher-and-hilla-becher-pitheads-t01922

Fig. 18: Henri Matisse, “Formes." Source: MoMA, Digital image. Available from: www.moma.org/collection/works/105387 
Fig. 19: Mike Merrill, "The nature of x-rays." Source: drmikemerrill.com, Digital image. Available from: drmikemerrill.com/students/nature-of-xrays

All images not included in this list are assumed to be the property of the author. 